\title{
HTGR Mechanistic Source Terms White Paper
}

The INL is a

U.S. Department of Energy

National Laboratory

operated by

Battelle Energy Alliance

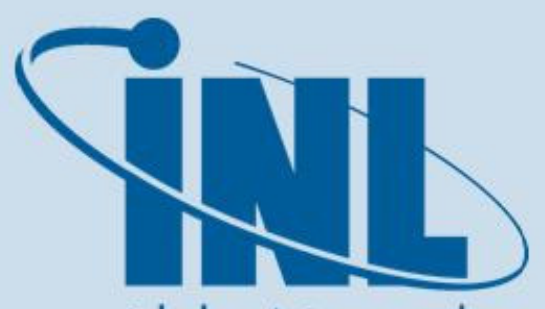

Idaho National Laboratory

July 2010

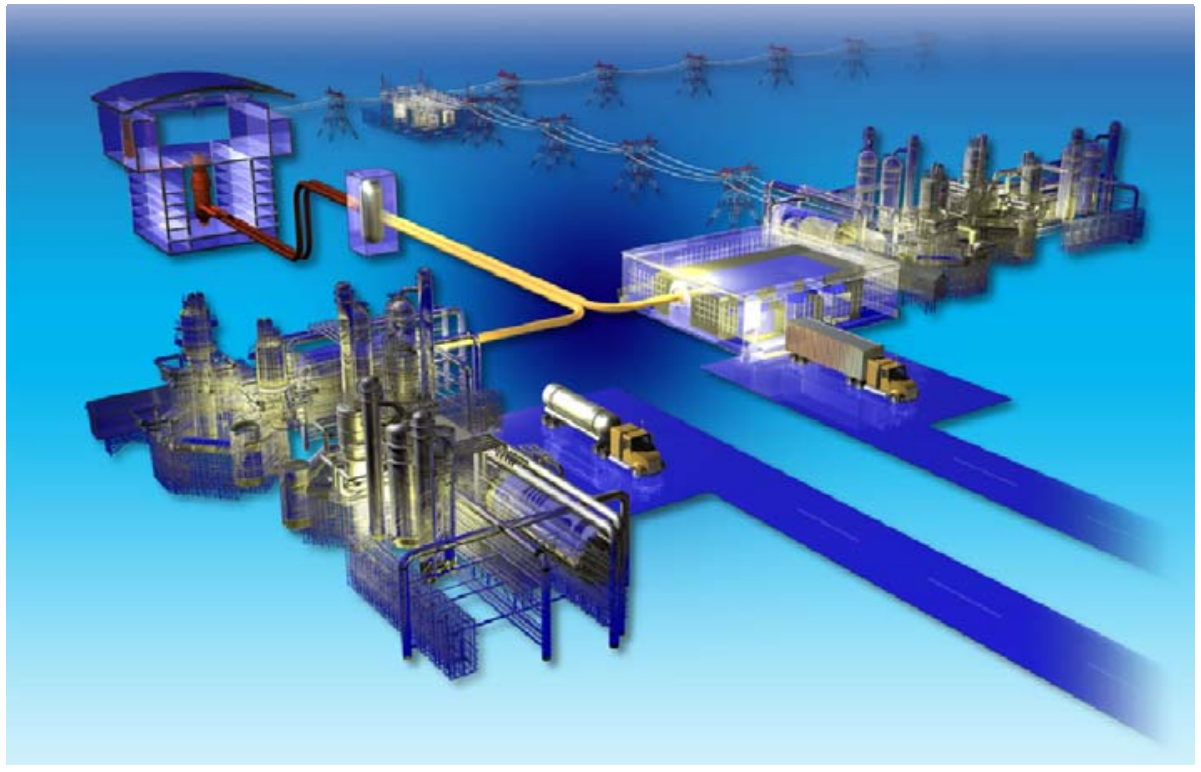




\section{DISCLAIMER}

This information was prepared as an account of work sponsored by an agency of the U.S. Government. Neither the U.S. Government nor any agency thereof, nor any of their employees, makes any warranty, expressed or implied, or assumes any legal liability or responsibility for the accuracy, completeness, or usefulness, of any information, apparatus, product, or process disclosed, or represents that its use would not infringe privately owned rights. References herein to any specific commercial product, process, or service by trade name, trade mark, manufacturer, or otherwise, does not necessarily constitute or imply its endorsement, recommendation, or favoring by the U.S. Government or any agency thereof. The views and opinions of authors expressed herein do not necessarily state or reflect those of the U.S. Government or any agency thereof. 
INL/EXT-10-17997

\section{HTGR Mechanistic Source Terms White Paper}

July 2010

Idaho National Laboratory

Next Generation Nuclear Plant Project

Idaho Falls, Idaho 83415

Prepared for the

U.S. Department of Energy

Office of Nuclear Energy

Under DOE Idaho Operations Office

Contract DE-AC07-05ID14517 


\section{Next Generation Nuclear Plant Project}

\section{Mechanistic Source Terms White Paper}

INL/EXT-10-17997

July 2010

Approved by:

Waype

NGNP Regula

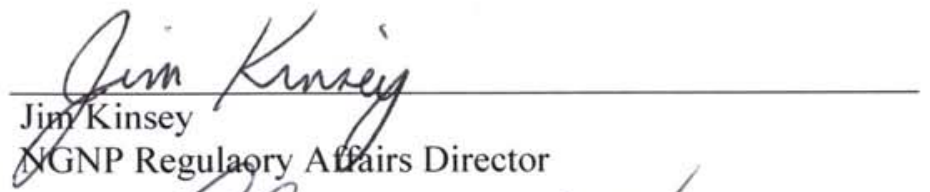

GNP Regulaory Affairs Director

Keith Perry

NGNP Engineering Director

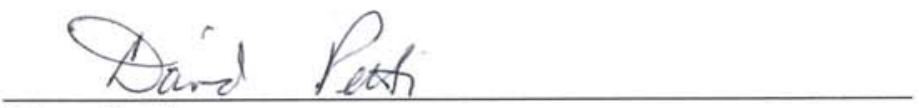

Dave Petti

VHTR R\&D Director

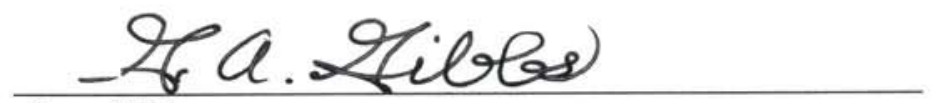

Greg Gibbs

FoekJP

NGNP Project Director
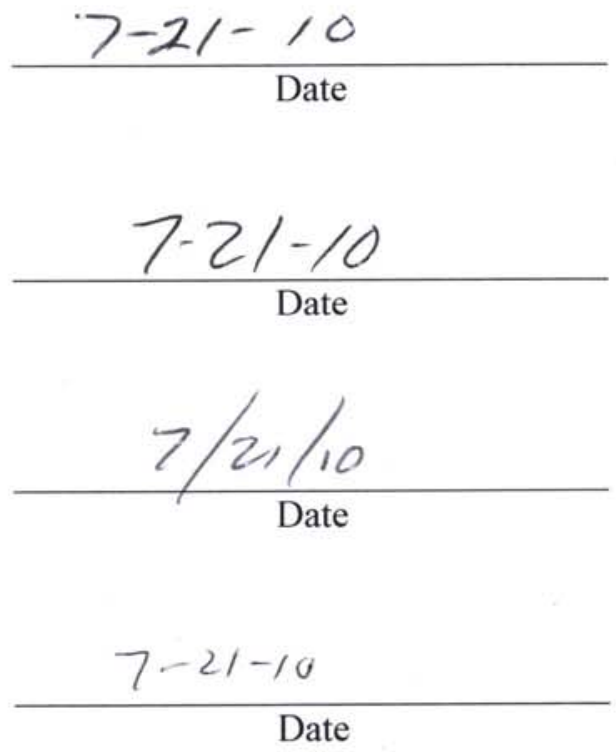

$7-2 /-10$

Date 


\section{ABSTRACT}

The Next Generation Nuclear Plant (NGNP) will be a Nuclear Regulatory Commission (NRC) licensed commercial high temperature gas-cooled reactor (HTGR) plant capable of producing electricity and high temperature process heat for industrial markets supporting a wide range of end-user applications. The NGNP Project has adopted the 10 CFR 52 Combined License (COL) application process, as recommended in the Report to Congress, dated August 2008, as the foundation for the NGNP licensing strategy. NRC licensing of the NGNP utilizing this process will provide the basis and support for licensing of future HTGRs. This white paper is one in a series of submittals that will address key COL priority licensing topics for which HTGR regulatory requirements need to be established as part of the licensing process.

This "Mechanistic Source Terms White Paper" summarizes the eventspecific mechanistic approach that the NGNP Project is taking in developing radiological source terms for licensing basis events. The source terms developed with this approach, and radionuclide inventories elsewhere in the facility that are determined during source term analysis, can also be used for other purposes, including equipment environmental qualification, control room habitability analyses, and assessments of severe accident risks in environmental impact statements. The mechanistic approach to source term development is required to establish the technical basis and take appropriate credit for the radionuclide retention capabilities of each of the multiple barriers to radionuclide transport to the environment consistent with the HTGR safety design approach.

The HTGR concepts currently being considered include both pebble bed and prismatic block reactors. The "Mechanistic Source Terms White Paper" is, to the extent possible, generic to these two reactor designs. Where it is appropriate, unique aspects of source term development are discussed.

This white paper provides information on the safety design basis of the HTGR. The regulatory foundation for use of event-specific mechanistic source terms is reviewed. The approach to developing mechanistic source terms is discussed, including information on radionuclide generation and transport in the core, primary circuit, and reactor building. The multiple barriers to radionuclide release are discussed, with particular emphasis on the role of the fuel particles as the primary (but not only) barrier to radionuclide release. The models and codes used in source term development are summarized, and the sources of supporting data are reviewed. Technical gaps in understanding radionuclide transport phenomena are summarized, and the current technology development plans that address those gaps are discussed.

The information in this paper is intended to serve as the basis for interactions with the NRC staff. The NGNP Project wishes to obtain comments on the adequacy of the planned mechanistic source term approach and feedback on a number of issues that have the potential to significantly impact the effort and schedule to prepare a COL application for the NGNP HTGR. 


\section{CONTENTS}

ABSTRACT. vi

ACRONYMS xii

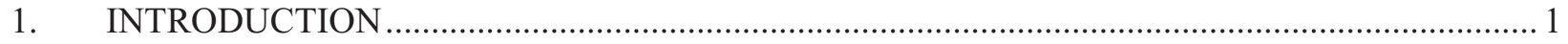

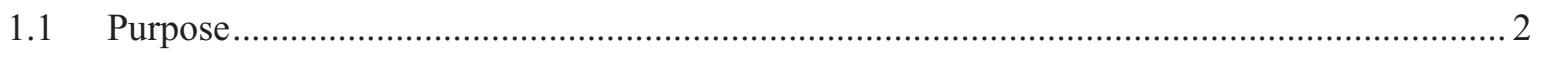

1.2 Scope

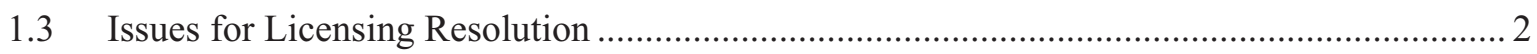

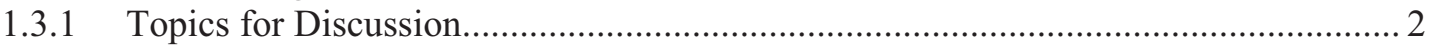

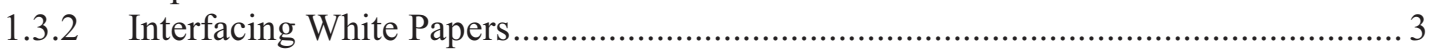

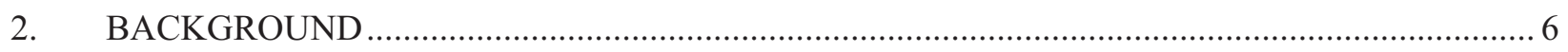

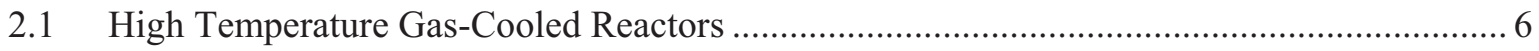

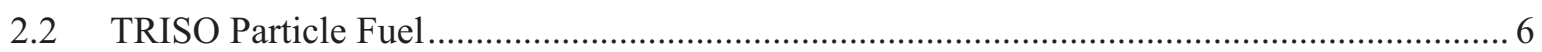

2.2.1 Fuel Design for Prismatic HTGRs .................................................................... 8

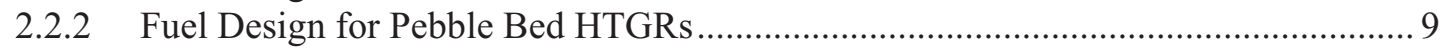

2.2.3 Fuel Particle and Fuel Element Fabrication ............................................................. 9

2.2.4 Status of $\mathrm{UO}_{2}$ and UCO TRISO Fuel Development and Qualification ..................... 10

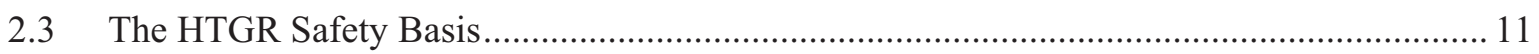

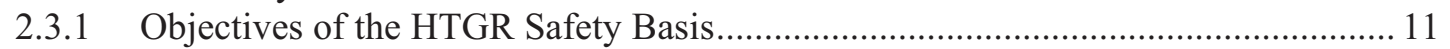

2.3.2 The Principal Barrier to Release of Radionuclides to the Environment .................... 11

2.3.3 Additional Factors Affecting Transport of Radionuclides and Release to the

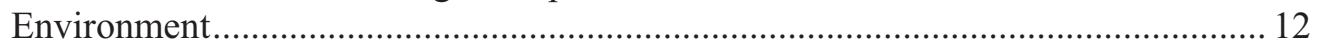

2.3.4 Reactor Passive and Inherent Design Characteristics that Contribute to the

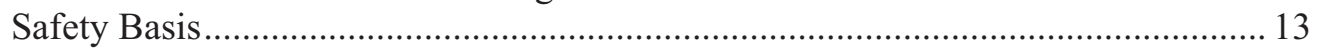

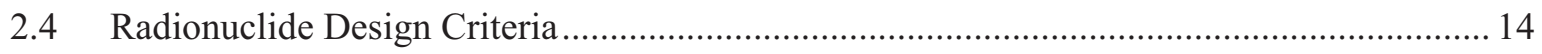

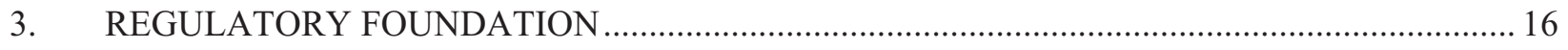

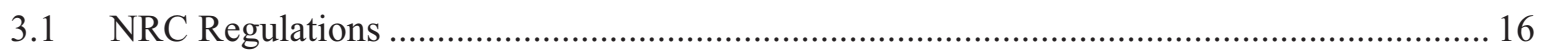

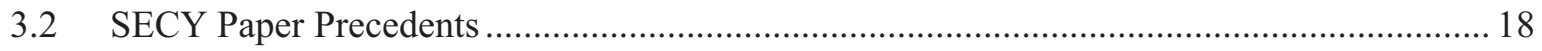

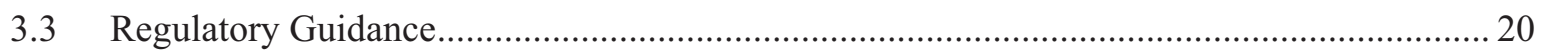

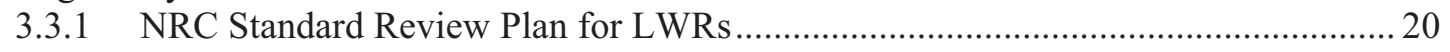

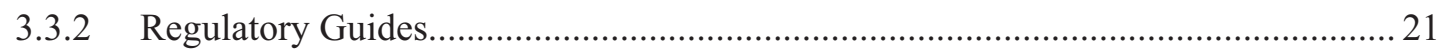

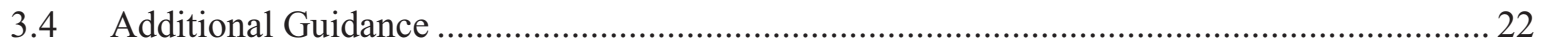

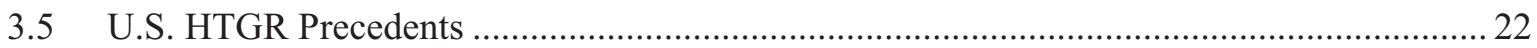

3.5.1 Peach Bottom Final Hazards Summary Report ................................................ 22

3.5.2 Fort St. Vrain Final Safety Analysis Report ….................................................... 22

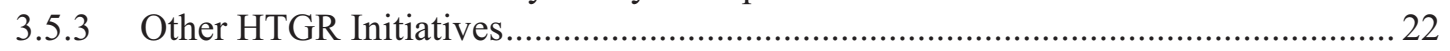

4. NGNP APPROACH FOR MECHANISTIC SOURCE TERMS …............................................ 25

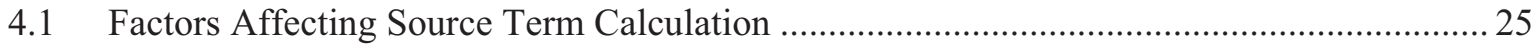

4.2 NGNP Top-Level Radionuclide Control Requirements ................................................. 25

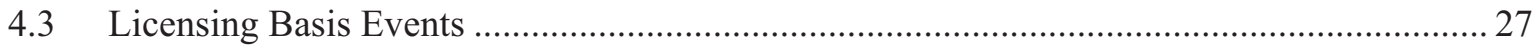

4.4 Radionuclide Transport and Retention in the HTGR ....................................................... 27

4.4.1 Radionuclide Behavior During Normal Operation ............................................. 28 


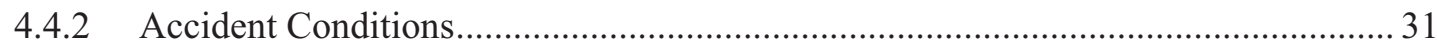

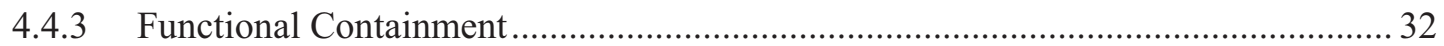

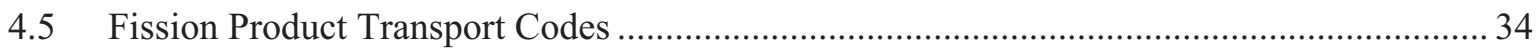

4.5.1 Prismatic Fuel Fission Product Transport Codes (General Atomics) ........................ 35

4.5.2 Pebble Fuel Fission Product Transport Codes (PBMR [Pty] Ltd.) ........................... 35

4.6 Radionuclide Transport Data from Operating HTGRs ................................................. 37

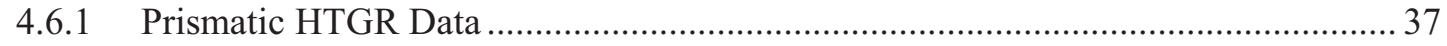

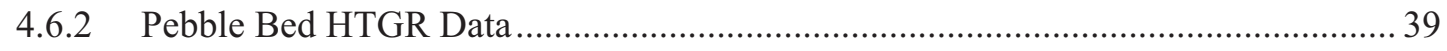

5. TECHNOLOGY DEVELOPMENT REQUIRED FOR SOURCE TERM VALIDATION .............43

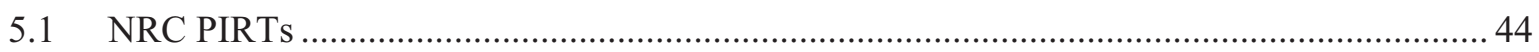

5.2 NGNP/AGR Fuel Program Plan for Source Term Validation ......................................... 44

5.2.1 Fuel Development and Qualification Program …........................................................ 46

5.2.2 Fission Product Transport Characterization Program .............................................. 47

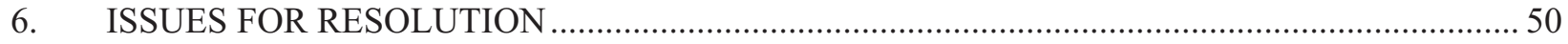

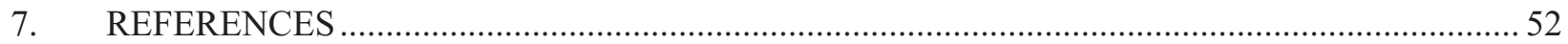

Appendix A A Brief History of High Temperature Gas-Cooled Reactor Development ......................... 55

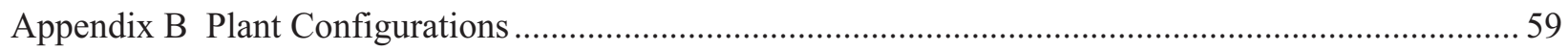

Appendix C Detailed Discussion of Fission Product Transport and Retention in the HTGR .................. 65

Appendix D Prismatic Code Descriptions (General Atomics) …........................................................ 83

Appendix E Description of PBMR Codes (PBMR (Pty) Ltd.) …......................................................... 91

\section{FIGURES}

Figure 1-1. Relationships with the mechanistic source terms white paper. .............................................. 5

Figure 2-1. TRISO fuel particle configuration and coating purposes..................................................... 7

Figure 2-2. Prismatic reactor fuel particles, compacts, and elements.................................................... 8

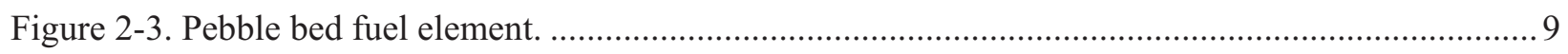

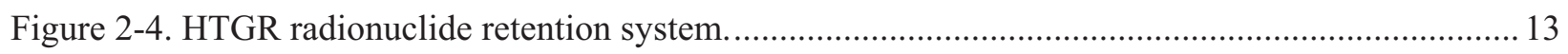

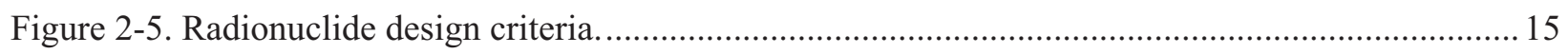

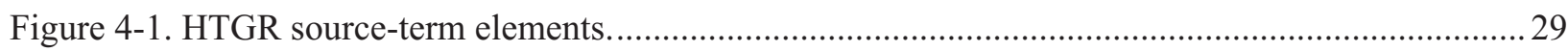

Figure 4-2. Relative contribution of each barrier to limiting radionuclide release to the environment for an example postulated depressurization event. ............................................. 33

Figure 4-3. Key interfaces between prismatic HTGR core analysis codes (General Atomics).................. 35

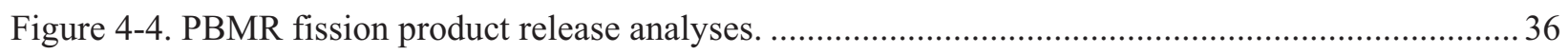

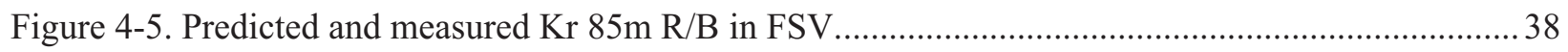

Figure 4-6. Calculated and measured fission-metal release in FSV ...................................................... 38 
Figure 4-7. Measured and calculated $88 \mathrm{Kr} \mathrm{R} / \mathrm{B}$ comparison for test element B1K6 (contamination release)

Figure 4-8. Measured and calculated 135mXe R/B comparison for element B1K6 (contamination release) 40

Figure 4-9. Measured and calculated $88 \mathrm{Kr} \mathrm{R} / \mathrm{B}$ comparison for test element $\mathrm{C} 1 \mathrm{~K} 6$. 41

Figure 4-10. Measured and calculated 135mXe R/B comparison for test element C1K6...................... 41

Figure A-1. Summary of experimental and commercial scale HTGR installations..................................56

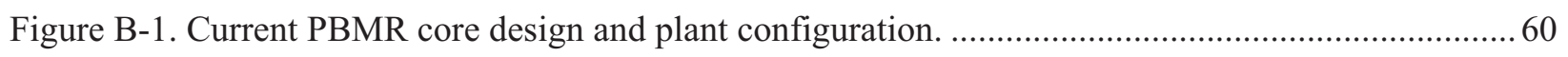

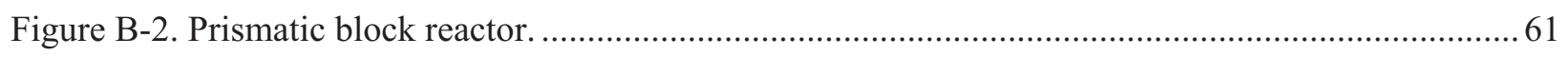

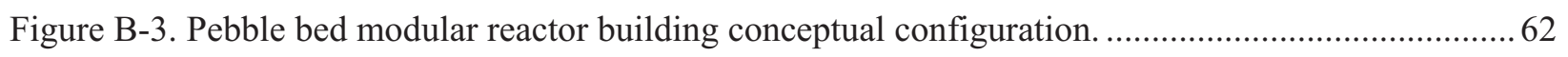

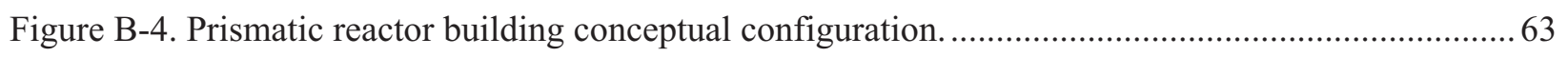

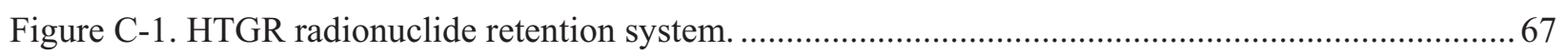

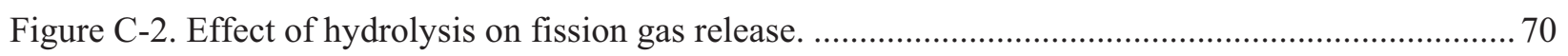

Figure C-3. Metal release during post-irradiation heating of HRB-22 particles at $1700^{\circ} \mathrm{C} \ldots \ldots \ldots \ldots \ldots \ldots \ldots . . . . . . . . .72$

Figure C-4. Predicted and measured Ag-110m plateout profiles in COMEDIE BD-1 1........................... 77

Figure C-5. Predicted and measured Cs-137 plateout profiles in COMEDIE BD-1 ...............................77

Figure E-1. PBMR fission product release analyses......................................................................... 92

\section{TABLES}

Table 3-1. NRC regulations relevant to HTGR mechanistic source-term development........................... 16

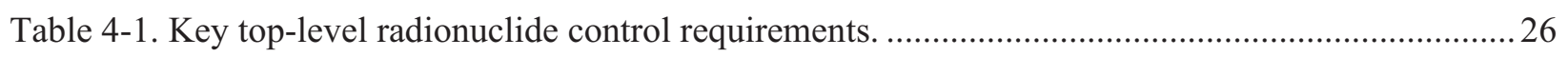

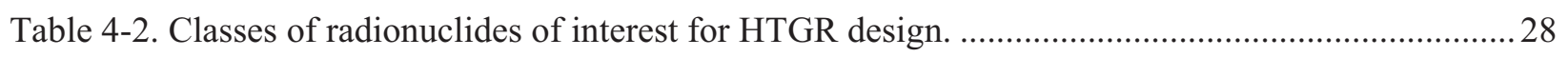

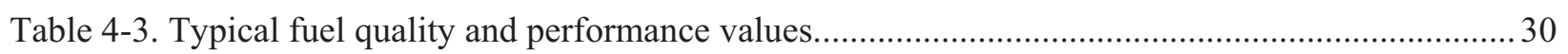

Table 5-1. Summary of major mechanistic source-term knowledge gaps. ............................................... 43

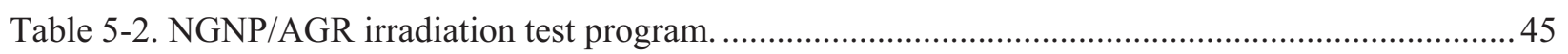

Table C-1. Measured and predicted liftoff in the COMEDIE BD-1 loop test ......................................... 79

Table D-1. General Atomics codes for predicting radionuclide source terms for prismatic HTGRs. ........ 84

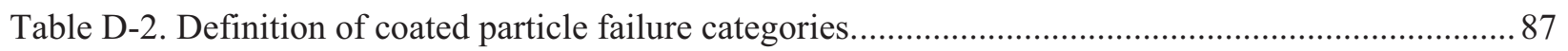




\section{ACRONYMS}

ACRS Advisory Committee on Reactor Safeguards

AGR Advanced Gas Reactor

ANS American Nuclear Society

AOO anticipated operational occurrences

AST alternative source term

AVR Arbeitsgemeinschaft Versuchsreaktor

BDBA beyond design basis accident

BISO bistructural isotropic

COL combined license

DAMD Dust and Activity Migration and Distribution

DBA design basis accident

DBE design basis event

DLOFC depressurized loss of forced cooling

DOE Department of Energy

DPP Demonstration Power Plant

DTF designed-to-fail

EAB exclusion area boundary

EPA Environmental Protection Agency

EPZ emergency planning zone

FIMA fissions per initial metal atom

FSV Fort St. Vrain

FY fiscal year

GASSAR General Atomic Standard Safety Analysis Report

GT-MHR gas-turbine modular helium reactor

HFR high-flux reactor

HPS helium purification system

HRB HochTemperatur Reaktorbau

HTGR high temperature gas-cooled reactor

HTR high temperature reactor

HTTR High Temperature Engineering Test Reactor (Japan)

IAEA International Atomic Energy Agency

INL Idaho National Laboratory

IPyC inner pyrocarbon 


$\begin{array}{ll}\text { LBE } & \text { licensing basis event } \\ \text { LEU } & \text { low-enriched uranium } \\ \text { LWR } & \text { light water reactor } \\ \text { MPS } & \text { main power system } \\ \text { NGNP } & \text { Next Generation Nuclear Plant } \\ \text { NRC } & \text { Nuclear Regulatory Commission } \\ \text { OPyC } & \text { outer pyrocarbon } \\ \text { ORNL } & \text { Oak Ridge National Laboratory } \\ \text { PAG } & \text { protective action guide } \\ \text { PBMR } & \text { pebble bed modular reactor } \\ \text { PIRT } & \text { Phenomena Identification and Ranking Table } \\ \text { PSID } & \text { preliminary safety information document } \\ \text { R/B } & \text { release rate-to-birth rate ratio } \\ \text { RAI } & \text { Request for Additional Information } \\ \text { SiC } & \text { silicon carbide } \\ \text { SR } & \text { shear ratio } \\ \text { SRM } & \text { Staff Requirements Memorandum } \\ \text { SRP } & \text { Standard Review Plan } \\ \text { TEDE } & \text { total effective dose equivalent } \\ \text { TRISO } & \text { tristructural-isotropic } \\ \text { UCO } & \text { uranium oxycarbide } \\ \text { VHTR } & \text { very high temperature reactor } \\ \text { VSOP } & \text { Very Superior Old Programs } \\ & \end{array}$




\section{Mechanistic Source Terms White Paper}

\section{INTRODUCTION}

The Next Generation Nuclear Plant (NGNP) Project was initiated at Idaho National Laboratory (INL) by the Department of Energy (DOE) as part of the Generation IV Nuclear Energy Systems technology roadmap and pursuant to the 2005 Energy Policy Act. The principal objective of the NGNP Project is to support commercialization of the high temperature gas-cooled reactor (HTGR) technology. The helium cooled and graphite moderated HTGR can operate at reactor outlet temperatures much higher than conventional light water reactor (LWR) technology. Accordingly, it can be applied in many industrial applications as a substitute for the burning of fossil fuels, such as natural gas, in addition to producing electricity - the principal application of LWRs. Applications of the HTGR technology to industrial processes that have been evaluated by the NGNP Project include supply of electricity, steam and high temperature gas to a wide range of industrial processes, and production of hydrogen and oxygen for use in petrochemical, refining, chemical, and fertilizer plants. The HTGR concepts currently being considered by the NGNP Project include both pebble bed and prismatic block reactors.

The HTGR has safety characteristics, which stem from material, nuclear, and thermal hydraulic characteristics, that mitigate the severity of postulated licensing basis events (LBEs) (e.g., loss of coolant pressure, reactivity transients) and reduce the release of the associated radiological source terms and calculated dose consequences. Because of the properties of the high temperature fuel and moderator that do not depend on the presence of the coolant pressure, the core cannot physically melt. During postulated accident events involving core heatup, a limited reduction in the effectiveness of the coated fuel particle radiological barriers in a small fraction of the core volume results only in limited (small) increases in radionuclide release from the fuel. These characteristics support one of the objectives of the HTGR safety basis, which is to limit calculated dose from releases so that regulatory requirements for protection of the health and safety of the public and protection of the environment are met at an exclusion area boundary (EAB) that is no more than a few hundred meters from the reactor (e.g., 400 to 425 meters). This will support the associated licensing objective of establishing the plant emergency planning zone (EPZ) at the EAB and support flexibility in siting the HTGR plant with the objective of locating the HTGR in close proximity to industrial processes to improve the efficiency of energy transport to the processes.

This white paper presents the event-specific ${ }^{a}$ mechanistic approach that the NGNP Project is taking in developing radiological source terms ${ }^{\mathrm{b}}$ for LBEs. The source terms developed with this approach, and the radionuclide inventories elsewhere in the facility that are determined during source term analysis, can also be used for other purposes, including equipment environmental qualification, control room habitability analyses, and assessments of severe accident risks in environmental impact statements. The mechanistic approach takes into account the inherent characteristics of the HTGR technology that provide multiple

a. Although the process for defining and selecting licensing basis events is the subject of a future white paper, it is expected, based on previous modular gas-cooled reactor safety analyses, that there will be no single limiting LBE for the HTGR. The conditions in the reactor core and the plant vary in time and space for each LBE and a source term is calculated for each event; thus the identification of the source terms as event-specific. The approach for the development of the source term for each LBE is based on establishing the effectiveness of the barriers to fission product transport under the plant conditions for each event calculated from the material, nuclear, and thermal hydraulic characteristics of the HTGR.

b. As used in this white paper, source term refers to the quantities, timing, physical and chemical forms, and thermal energy of radionuclides (used herein interchangeably with fission products) released from the reactor building to the environment during postulated accidents. Traditionally, the expression source term can also have broader meanings. For example, in LWRs the source term refers to the quantities of radionuclides released to the containment building under accident conditions. Source term may also refer to the quantities of radionuclides that must be shielded when a shipping cask is designed or to the concentrations of radionuclides deposited on a steam generator tube bundle when the gamma dose rates associated with tube plugging are calculated. 
barriers to fission product transport to the environment in developing the source terms. The deterministic methodology used by LWRs to establish source terms related to a severe core melt accident is not adequate to take these safety characteristics into account for HTGRs.

The "Mechanistic Source Terms White Paper" is, to the extent possible, generic to the two reactor designs being considered by the NGNP Project. Where appropriate, unique aspects of source term development are discussed.

\subsection{Purpose}

The primary purposes of this white paper are to (1) define and describe the proposed approach for developing event-specific mechanistic source terms for HTGR design and licensing, (2) describe the technology development programs, as currently developed, needed to validate the design methods used to predict these mechanistic source terms, and (3) obtain agreement from the Nuclear Regulatory Commission (NRC) that, subject to appropriate validation through the technology development program, the approach for developing event-specific mechanistic source terms is acceptable.

\subsection{Scope}

This white paper addresses the following topics:

- Issues for licensing resolution including policy and technical issues

- The regulatory policy and guidance available for application of mechanistic source terms for HTGR designs

- The top-level regulatory requirements on calculated dose applied by the project to ensure the health and safety of the public and the plant workers and to protect the environment

- The expected fission product sources associated with a graphite core containing tristructural-isotropic (TRISO)-coated particle fuel (including transport through the various fuel particle layers) and other sources of circulating activity, such as contaminated dust

- The various mechanisms of holdup for fission products within the fuel element, core graphite, helium pressure boundary, and reactor building and the influence that the reactor building design would have on atmospheric releases

- The various analytical tools currently used to calculate event-specific mechanistic source terms

- Discussion of outstanding issues to be resolved and the technology development programs in process and planned to validate the process and analytic tools used to calculate the event-specific mechanistic source terms.

The following summarizes the policy and technical issues addressed in this white paper and the expected outcome of the discussions with NRC.

\subsection{Issues for Licensing Resolution}

\subsubsection{Topics for Discussion}

The information contained in this white paper is intended to serve as the basis for licensing topic interactions with the NRC staff. The NGNP Project wishes to obtain NRC's agreement on the adequacy of the planned event-specific mechanistic source terms approach and to obtain their feedback on any issues that can significantly impact the effort and schedule to prepare a Combined License (COL) application for a first-of-a-kind HTGR plant under the NGNP Project. The following are specific areas 
where agreement on the NGNP Project's approach to calculating event-specific mechanistic source terms is being sought:

- Agreement that the definition of event specific mechanistic source terms for the HTGR is acceptable.

- Agreement that the approach to calculating event-specific mechanistic source terms for the HTGR technology is acceptable, subject to validation of the design methods and supporting data that form the bases of the calculations.

Specifically, this approach analyzes a functional containment comprising several barriers that limit the release of radionuclides to the environment (defined herein as the source term) for each postulated event, including normal operating conditions, abnormal operating conditions, and accident conditions. The multiple barriers include individual fuel particle kernels and coatings, the fuel matrix and fuel element graphite, the helium pressure boundary (primary circuit), and a vented low-pressure reactor building. ${ }^{\mathrm{c}}$ Design methods for determining radionuclide source terms, which include analytical tools used to calculate the performance of each of these barriers during radionuclide transport under eventspecific conditions are defined and supported by testing and analysis. These analytical tools are applied in calculations for normal operating conditions, abnormal operating conditions, design basis accident (DBA) conditions, and beyond design basis accident (BDBA) conditions:

- Generation and transport of each radiologically significant species of fission product from the fuel kernel through the TRISO particle coatings and fuel element graphite into the reactor coolant as a function of as-manufactured quality of the TRISO fuel coatings (including heavy metal contamination) and postulated in-service and accident condition coating failure rates as a function of fuel burnup, power level, temperature (including time at temperature), and, where applicable, air and water contamination.

- The concentration and form of each radiologically significant species of radionuclide in the helium primary circuit (those released from the fuel elements) under steady-state full power and temperature operating conditions, including circulating activity and plate out of condensable radionuclides on primary circuit components; the effects of dust generation, fallout, and radionuclide absorption; radionuclide half life; and operation of the helium purification system.

- The concentration and form of each radiologically significant species of radionuclide in helium released from the helium pressure boundary under depressurization events as a function of time considering the location and time-dependent rate of coolant release, reentrainment of accumulated dust, liftoff of plated-out radionuclides, and the effects of time-dependent air and/or moisture ingress on these parameters.

- The effects of radionuclide form, condensation, settling, vent-path configuration, and vent filtering, if any, on the time-dependent calculation of radionuclide transport through the reactor building and the source term release to the atmosphere for each event.

- Agreement on the acceptability of the approach of the planned fission product transport tests of the NGNP/Advanced Gas Reactor (AGR) Fuel Development and Qualification Program, as supplemented by the existing irradiation and post-irradiation heating data bases, to validate these fission product transport analytical tools.

\subsubsection{Interfacing White Papers}

This paper on mechanistic source terms is one of several white papers covering key regulatory issues being prepared and submitted for NRC review and comment as part of the NGNP Project licensing

c. The HTGR vented low-pressure reactor building includes the cavities enclosing the reactor, steam generator and intermediate heat exchanger (where used depending on the plant configuration), and other volumes in the building. There may be dampers located between the cavities and the other volumes that permit free flow from the cavities to the other volumes but restrict flow from the other volumes to the cavities. 
strategy. Many of the other white papers have direct bearing on the development of mechanistic source terms. White papers that are expected to be submitted by the Project are summarized in the NGNP Licensing Plan (INL 2009). These papers, together with later topical reports, that are most closely related to this paper include:

- Defense-in-Depth Approach, INL/EXT-09-17139, December 2009

- Licensing Basis Event Selection

- Structures, Systems, and Components Classification

- Fuel Qualification, INL/EXT-10-17686, July 2010

- Core Design and Heat Removal

- Computer Code Verification and Validation

- Regulatory Technology Development

- Emergency Planning Zone Analysis

- Nuclear-Industrial Island Boundary

- Co-location at Industrial Site

- Air \& Water Ingress Effects.

The relationships among these white papers and topical reports and this white paper are depicted in Figure 1-1. The interfacing documents shown in Figure 1-1 support developing and validating the effectiveness of the fission product transport barriers, the design and inherent safety characteristics of the HTGR, and the analytical tools (e.g., computer codes) used in design and safety analyses, including calculation of source terms.

In particular it should be noted that the Mechanistic Source Terms White Paper, Fuel Qualification White Paper, and Licensing Basis Event Selection White Paper need to be reviewed as a package of closely related documents that together present the major elements of the HTGR safety basis. The Fuel Qualification White Paper is being submitted to the NRC at the same time as the Mechanistic Source Terms White Paper. The Licensing Basis Event Selection White Paper is expected to be submitted to the NRC soon after submittal of this paper on mechanistic source terms. 


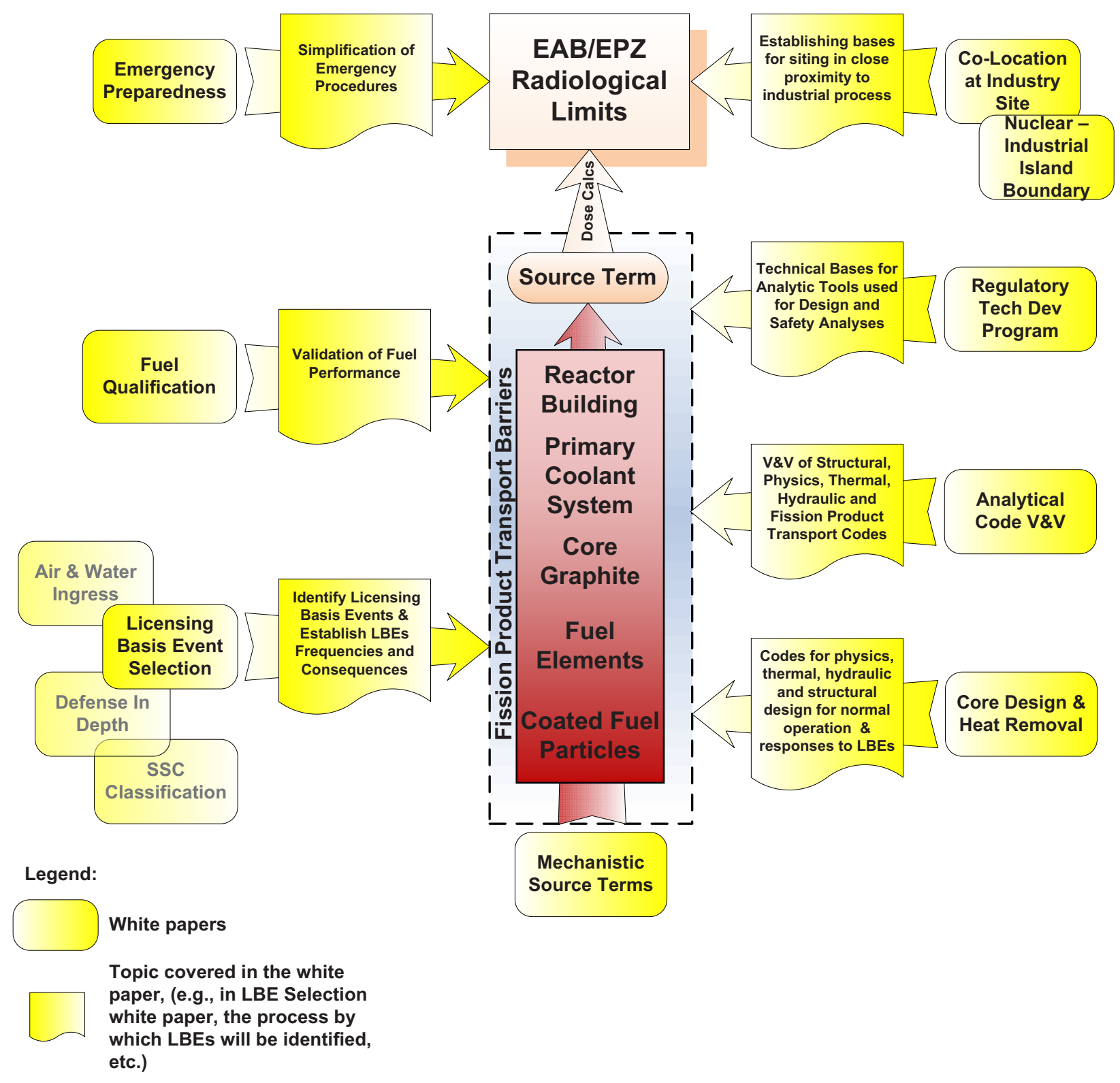

Figure 1-1. Relationships with the mechanistic source terms white paper. 


\section{BACKGROUND}

\subsection{High Temperature Gas-Cooled Reactors}

The current designs of the high temperature gas-cooled graphite moderated reactor have resulted from extensive experimental and commercial gas-cooled reactor operations and significant design activity by gas-cooled reactor suppliers and several governments. The HTGR concept evolved from early air-cooled and carbon dioxide $\left(\mathrm{CO}_{2}\right)$-cooled reactors. The use of helium instead of air or $\mathrm{CO}_{2}$ as the coolant in combination with ceramic fuel and a graphite moderator offered enhanced neutronic and thermal efficiencies and several advanced safety characteristics. The combination of helium coolant and graphite moderator makes it possible to produce high temperature nuclear heat. Two reactor core configurations, a pebble bed core and a prismatic core, have been developed for the commercial HTGR designs.

Appendix A provides a brief summary of the history of the development of the HTGR designs that preceded and provided the basis for the technologies being developed and commercialized by the NGNP Project. Appendix B provides a brief summary of the configurations of the preconceptual pebble bed and prismatic block reactor-based plant designs being considered for the NGNP Project.

The history of HTGR operating conditions in test and commercial reactors (Appendix A) presents a wide range of reactor power levels (10 to $842 \mathrm{MWth}$ ) and reactor outlet temperatures, (e.g., $700-950^{\circ} \mathrm{C}$ ). In fiscal year (FY)-07, the NGNP Project completed preconceptual designs of pebble bed and prismaticreactor-based designs that have ratings in the 500 to $600 \mathrm{MWth}$ range and reactor outlet temperatures up to $950^{\circ} \mathrm{C}$. Subsequent to that work, (1) evaluations of technical risks to successful completion of the Project within the schedule laid out in the 2005 Energy Policy Act (first-of-a-kind plant on-line in 2021), and (2) discussions with potential end users of the technology on their energy needs in this time frame resulted in reductions in the reactor power ratings and reactor outlet temperatures for the plant configurations described in Appendix B $\left(700-800^{\circ} \mathrm{C}\right.$ reactor outlet temperatures). However, there is significant advantage to ultimately achieving the higher reactor outlet temperatures to meet the needs of a wider range of applications. Accordingly, the NGNP Project Technology Development Program is being conducted to support qualification and codification of the reactor fuel, fuel and core graphite, and high temperature materials at their ultimate capabilities. The general process described in this paper for establishing mechanistic source terms is intended to support design and licensing of the HTGR over a range of operating power levels and reactor outlet helium temperatures that meet as wide a range of potential end-user energy needs as achievable. This approach provides a wide margin for design and licensing at the lower HTGR supplier-proposed design conditions and supports future designs and licensing at higher temperature and power levels.

\subsection{TRISO Particle Fuel}

As discussed in the Fuel Qualification White Paper (INL 2010), coated particle fuel has been used in HTGRs since their inception. TRISO coated particle fuel was first introduced in the Dragon reactor, and Fort St. Vrain was the first electricity producing HTGR with an all TRISO-particle core. TRISO-coated particle fuel has been the fuel of choice for all modular HTGR designs.

TRISO fuel particles consist of a fuel microsphere (kernel), typically formed from uranium dioxide $\left(\mathrm{UO}_{2}\right)$ or uranium oxycarbide $(\mathrm{UCO})^{\mathrm{d}}(350-500$ microns in diameter), that is coated with multiple layers of pyrocarbon and silicon carbide $(\mathrm{SiC})$ as shown in Figure 2-1. Finished particle diameters are 780-920 microns. The different coating layers consisting of the buffer, inner pyrolytic carbon (IPyC), $\mathrm{SiC}$, and outer pyrolytic carbon (OPyC) layers are referred to collectively as a TRISO (tri-isotropic)

d The proper notation for uranium oxycarbide is $\mathrm{UC}_{\mathrm{x}} \mathrm{O}_{\mathrm{y}}$ with $\mathrm{x}$ being the mole fraction of carbon and $\mathrm{y}$ being the mole fraction of oxygen. However, for simplicity, $\mathrm{UC}_{\mathrm{x}} \mathrm{O}_{\mathrm{y}}$ is referred to simply as $\mathrm{UCO}$ throughout this paper. 
coating. The coating system constitutes a miniature multishell pressure vessel that provides retention of the fission product gases that are generated by fissioning of the nuclear material in the kernel. A substantial fraction of the fission products are retained inside the kernel itself.
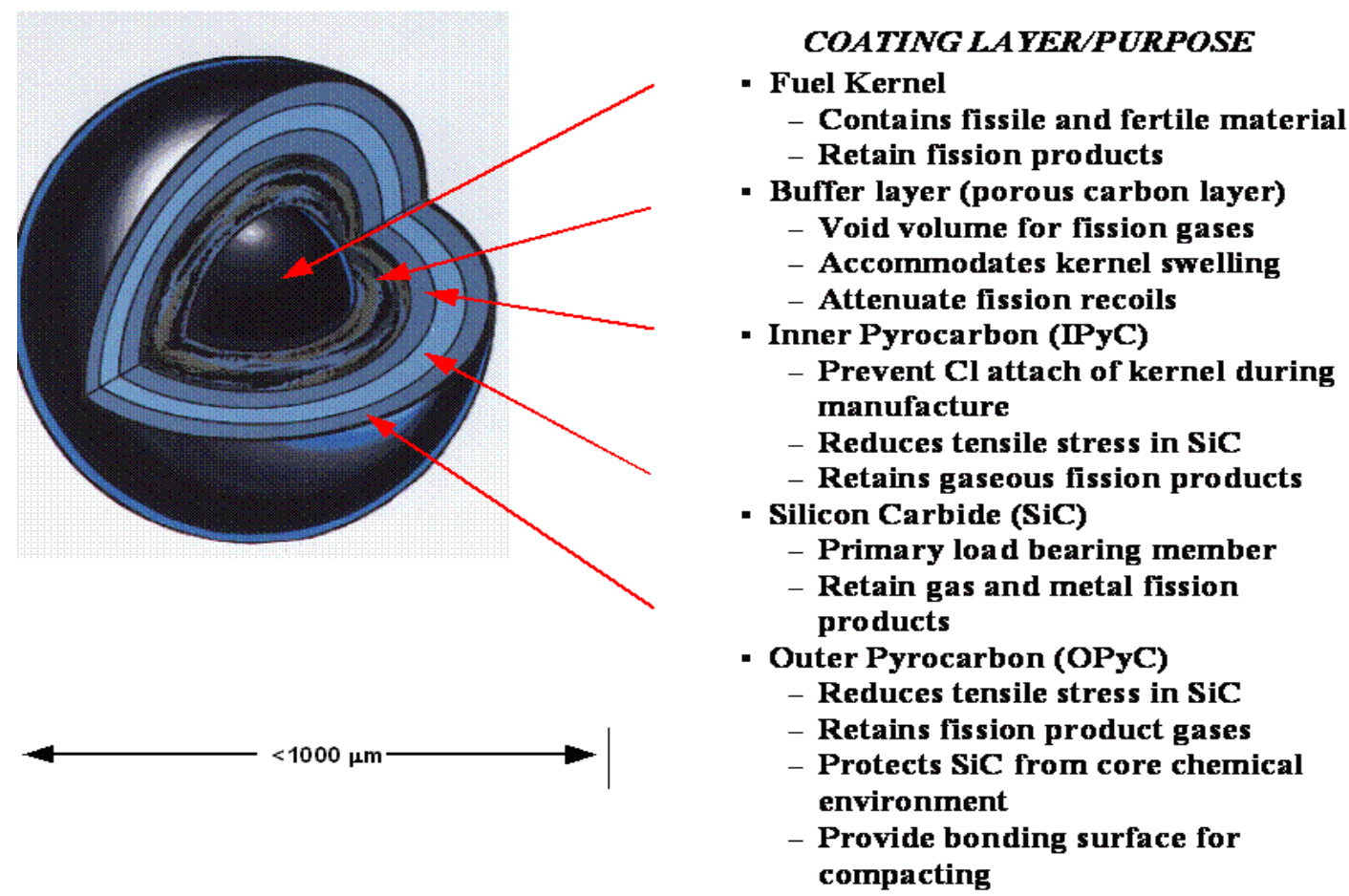

Figure 2-1. TRISO fuel particle configuration and coating purposes.

The four coating layers of a TRISO particle have specialized purposes as shown in Figure 2-1, but, in composite, they constitute a high-integrity pressure vessel that is extremely retentive of fission products. The purpose of the low-density buffer layer is to provide a reservoir for fission gases released from the fuel kernel to attenuate fission recoils and accommodate kernel swelling under irradiation. The main purposes of the high-density IPyC coating are to provide a smooth regular substrate for the deposition of a high integrity $\mathrm{SiC}$ coating and prevent chlorine $\left(\mathrm{Cl}_{2}\right)$ and hydrogen chloride $(\mathrm{HCl})$ from permeating the fuel kernel during the $\mathrm{SiC}$ deposition process; hence, a major benefit of the IPyC coating is realized during fuel fabrication. The IPyC coating, which is intimately bonded to the $\mathrm{SiC}$ coating, also helps to maintain the $\mathrm{SiC}$ coating in compression, as the former shrinks under irradiation, while the latter is dimensionally stable.

The SiC coating is the most important coating in a TRISO particle because it provides most of the structural strength and dimensional stability and serves as the primary barrier to the release of fission products, particularly some of the volatile metallic fission products such as cesium. The high-density OPyC coating, which shrinks under irradiation, also generates a compressive stress in the dimensionally stable $\mathrm{SiC}$, partially compensating for the tensile stress component induced by the internal gas pressure. The PyC coatings also effectively retain fission gases in fuel particles with defective (as manufactured) or failed (in service) $\mathrm{SiC}$ layers up to about $1800^{\circ} \mathrm{C}$.

The properties of the TRISO particles are among the most important factors determining the radiological safety of the HTGR. This is because fission product retention in the fuel, as well as the fuel burnups and temperatures that can be tolerated in the reactor core, are primarily determined by the fuel particle properties. 


\subsubsection{Fuel Design for Prismatic HTGRs}

The fuel element for a prismatic HTGR is illustrated in Figure 2-2. The reference fuel particle consists of a TRISO-coated UCO fuel kernel. The fuel particles are bonded together in a carbonaceous matrix to form cylindrical compacts that are approximately $12.5 \mathrm{~mm}$ in diameter and up to about $50 \mathrm{~mm}$ in length. These compacts are loaded into hexagonal-shaped blocks that are fabricated from high-purity, nuclear grade graphite and have a pattern of blind fuel holes and coolant holes through which helium coolant flows. The blocks are about $793 \mathrm{~mm}$ high and about $360 \mathrm{~mm}$ wide across the flats and are referred to as fuel elements.

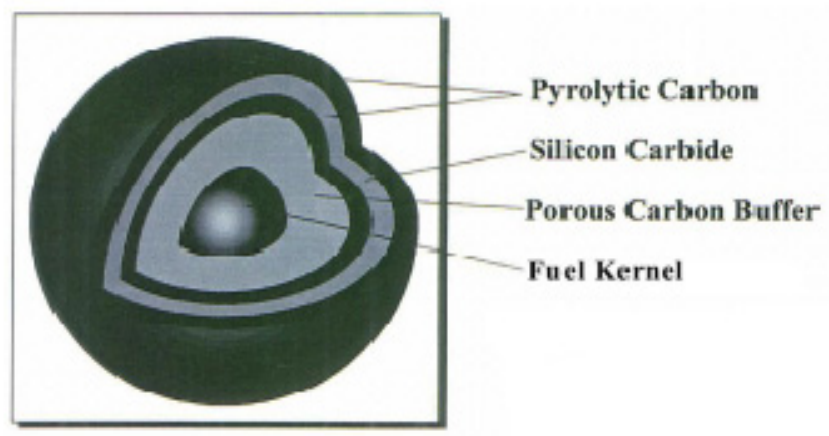

FUEL PARTICLE

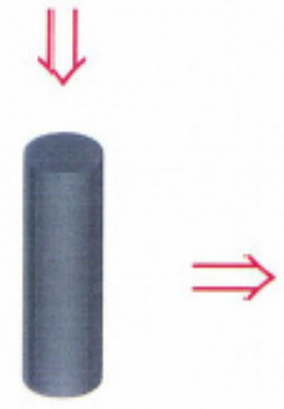

FUEL COMPACT
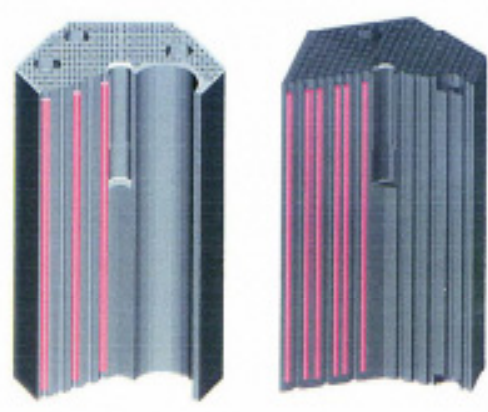

FUEL ELEMENTS

Figure 2-2. Prismatic reactor fuel particles, compacts, and elements.

The fuel type selected for development and qualification by the NGNP/AGR Fuel Development and Qualification Program (INL 2008) for the prismatic modular HTGR designs is UCO. The UCO kernel composition was selected primarily because of its ability to perform well at high fuel burnup under prismatic fuel irradiation conditions, which significantly improves the economics of a prismatic modular HTGR. The UCO kernel, which is actually a $\mathrm{UO}_{2}$ kernel to which $\mathrm{UC}_{2}$ and/or $\mathrm{UC}$ has been added, is an example of a gettered $\mathrm{UO}_{2}$ kernel in which a material has been added to reduce the oxygen potential of the kernel. The carbide component of the kernel undergoes oxidation to getter excess oxygen released during fission. At high burnup, the UCO kernel retains sufficient carbon to maintain a thermodynamic buffering effect. Gettering of excess oxygen reduces the formation of carbon monoxide during irradiation via the reaction of excess oxygen with the carbon buffer layer. Reducing the carbon monoxide formation during irradiation lessens the likelihood of failure of the coating system by overpressurization, kernel migration, and/or $\mathrm{CO}$ corrosion of the $\mathrm{SiC}$ at high temperatures. The oxide component of the kernel is highly effective at retaining many radionuclides that can chemically attack the $\mathrm{SiC}$ layer, especially the lanthanide isotopes. 
Earlier prismatic modular HTGR designs were based on a two-particle system utilizing a $19.8 \%$-enriched UCO fissile particle and $\mathrm{ThO}_{2}$ fertile particle, subsequently replaced by a natural uranium UCO fertile particle. Currently a single UCO fissile particle design having a range of U-235 enrichments for the shaping of flux distributions (typically about $14 \%$ enrichment) is assumed for the prismatic HTGR.

\subsubsection{Fuel Design for Pebble Bed HTGRs}

The TRISO fuel particle used in the pebble bed reactor is similar to that used in the prismatic reactor except the fuel kernel consists of stoichiometric uranium dioxide $\left(\mathrm{UO}_{2}\right)$. The $\mathrm{UO}_{2}$ kernel composition was chosen based on the experience in the German High Temperature Reactor (HTR) program, in which $\mathrm{UO}_{2}$ coated particle fuel with very low levels of as-manufactured defects and excellent inservice performance was developed. The fuel for the pebble bed reactor consists of spherical fuel elements as shown in Figure 2-3. The fuel element consists of a matrix graphite body pressed into a spherical shape. A fuel sphere is divided into two regions: the inner spherical region is known as the fuel region, and the outer shell surrounding the fuel region is known as the fuel-free region. The fuel region of each fuel sphere contains a large number of evenly distributed TRISO-coated fuel particles, while there are no particles in the fuel-free region. The relatively low particle packing fraction in the fuel region leads to lower temperature gradients across the fuel particle as compared to prismatic fuel designs, which enables the use of $\mathrm{UO}_{2}$ fuel and provides lower maximum fuel temperatures during normal operation. The design of the coated particles and fuel sphere, including their nominal dimensions, is depicted in Figure 2-3. The fuel-free region is a protective 5-mm-thick layer of matrix material formed by a high-pressure isostatic pressing process and machined to final dimensions.

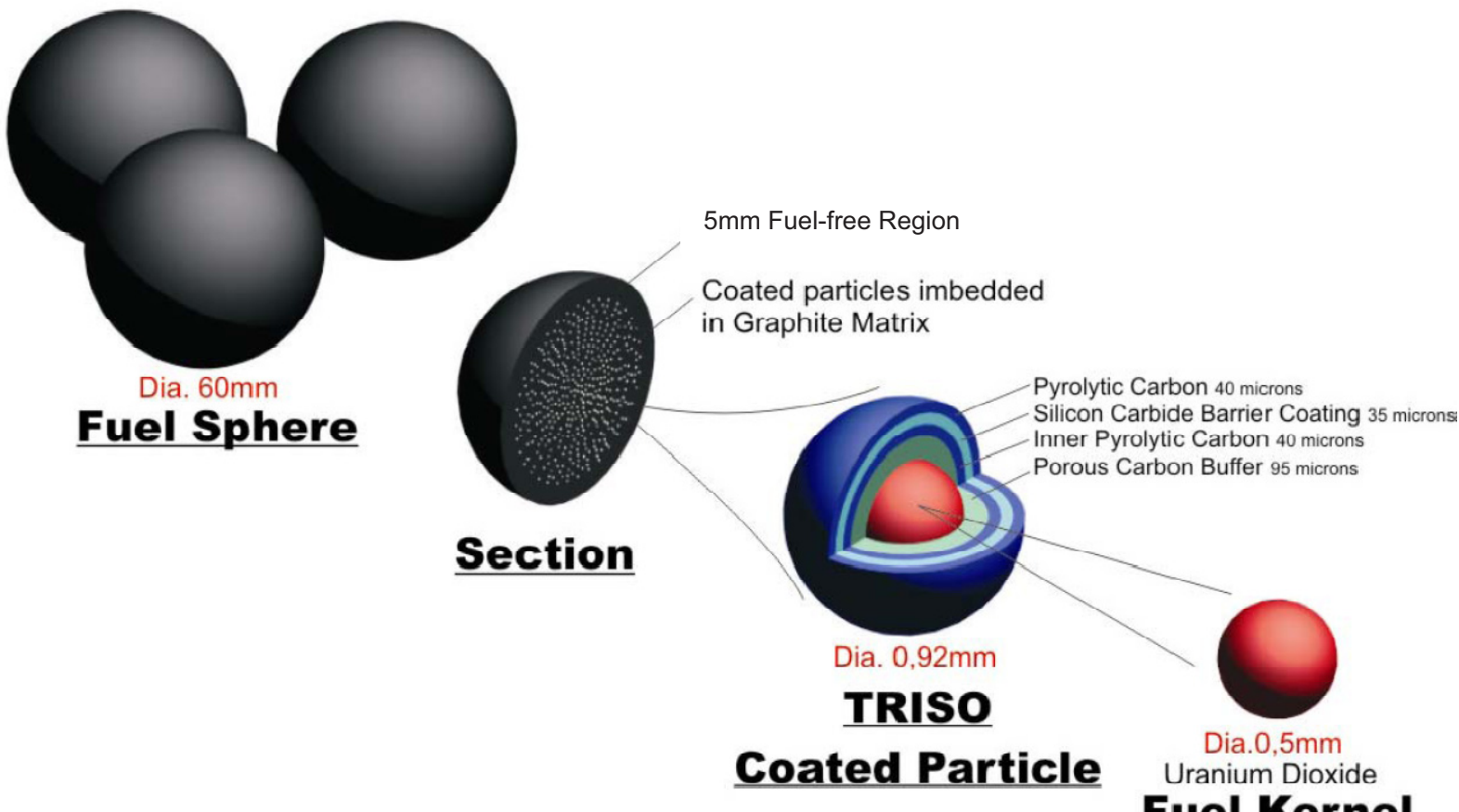

Figure 2-3. Pebble bed fuel element.

\subsubsection{Fuel Particle and Fuel Element Fabrication}

The TRISO coating system being developed today is based on the successful German low-enriched uranium (LEU) $\mathrm{UO}_{2}$ TRISO particle design. The German experience provides the basis for the 
NGNP/AGR LEU UCO particle design preferred for use in the prismatic HTGR and the $\mathrm{UO}_{2}$ particle design preferred for use in the pebble bed HTGR. The processes for manufacturing spherical fuel elements and the prismatic fuel elements are described in the "Fuel Qualification White Paper" (INL 2010). The kernel fabrication processes are similar, and the coating processes are virtually identical as are the Quality Control techniques. The processes for forming the fuel spheres and the cylindrical fuel compacts are different mechanically, but the resin-based matrix material is very similar for the two designs. The fabrication of the graphite fuel blocks is unique to the prismatic core design, and the fabrication of the protective fuel-free region of the spherical fuel element is unique to the pebble bed core design. Typical coated particle packing fractions in the fuel element are about $10 \%$ for the pebble bed fuel and on the order of $35 \%$ or more for the prismatic fuel.

\subsubsection{Status of $\mathrm{UO}_{2}$ and UCO TRISO Fuel Development and Qualification}

As discussed in the "Fuel Qualification White Paper" (INL 2010), there is an extensive database demonstrating the outstanding performance of high quality $\mathrm{UO}_{2}$ fuel at burnups $<10-12 \%$ fissions per initial metal atom (FIMA) under irradiation and during post-irradiation heating tests. TRISO-coated $\mathrm{UO}_{2}$ particles for the German HTR MODUL and the Japanese High Temperature Engineering Test Reactor (HTTR) programs have been successfully tested to the peak service conditions for those programs. The ultimate capability of $\mathrm{UO}_{2}$ kernels has not yet been established, but TRISO-coated $\mathrm{UO}_{2}$ has been successfully tested to $\sim 15 \%$ burnup (limited high burnup data) and a fast neutron fluence of $6.2 \times 10^{25} \mathrm{n} / \mathrm{m}^{2}$ at temperatures up to $1063^{\circ} \mathrm{C}$ without evidence of detrimental effects of $\mathrm{CO}$ generation or kernel migration.

The UCO database is less extensive. High-density UCO kernels have been irradiated in 12 irradiation test capsules in the U.S. and Germany and in the Arbeitsgemeinschaft Versuchsreaktor (AVR) in Germany. Some of the earlier U.S. program UCO irradiations did not meet performance requirements, especially the so-called TRISO-P variant, but for reasons that appear unrelated to the performance of the UCO kernel (INL 2010). The irradiations generally confirmed that the UCO kernels retained lanthanide fission products in the kernels and suppressed kernel migration and $\mathrm{CO}$ formation.

In view of the less-extensive database for UCO fuel, a key strategy adopted by the NGNP/AGR Fuel Development and Qualification Program was to replicate the successful German TRISO-coating system design on UCO fuel kernels. This approach appears to be succeeding as evidenced by the recently completed AGR-1 irradiation test, wherein no particle failures were observed during irradiation (Petti 2010). A fallback alternative for the prismatic fuel version is to use $\mathrm{UO}_{2}$ fuel particles in the startup core and gradually change the fuel composition to UCO during later refuelings.

Prior to the AGR-1 irradiation, the only irradiation of UCO under representative prismatic modular HTGR temperatures and burnup (but low fast fluence) that showed excellent fuel performance with regard to in-pile gaseous fission product release was German capsule FRJ2-P24 (Borchardt, Hürttlen, and Pott 1982). However, the Germans did not perform any post-irradiation heating tests on the fuel from this capsule. A significant number of post-irradiation tests have been performed with U.S.-made UCO fuel, mostly as loose particles and also in compacts, but these test articles did not meet the current prismatic HTGR as-manufactured fuel quality requirements. Nevertheless, these tests are instructive in that they did not show any significant qualitative performance differences between TRISO-coated UCO and $\mathrm{UO}_{2}$ particles. There is, however, a large body of accident simulation heating test data for high-quality $\mathrm{UO}_{2}$ fuel from the German program that demonstrates the excellent accident condition performance of the $\mathrm{UO}_{2}$ fuel (INL 2010). 


\subsection{The HTGR Safety Basis}

\subsubsection{Objectives of the HTGR Safety Basis}

The HTGR safety basis supports the same objective as that of the LWRs - designing, constructing, maintaining, and operating the plant to ensure the health and safety of the public and workers and protection of the environment under all normal, abnormal, and postulated accident conditions. However, the HTGR safety basis is different from that of the currently licensed LWRs, which focuses on preventing and mitigating core damage and large early release of radionuclides in the event of core damage. The safety basis of the HTGR, however, precludes core damage sufficient to significantly affect radiological consequences and, therefore, focuses on preventing and limiting the release of relatively small amounts of radioactive material as a result of event sequences that could occur with this design. The calculation of the source terms for these conditions is event-specific and requires validating the characteristics and integrity of barriers to transport and release of radionuclides from the plant for each event.

An objective of the safety basis is to limit a calculated dose from releases so that regulatory requirements for protection of the health and safety of the public and protection of the environment are met at an EAB that is no more than a few hundred meters from the reactor (e.g., 400 to 425 meters). This will support the associated licensing objective of establishing the plant EPZ at the EAB. This then supports flexibility in siting the HTGR plant with the objective of locating the HTGR in close proximity to industrial processes to improve the efficiency of energy transport to the processes.

As noted previously, the source term for the HTGR is defined as the quantities of radionuclides released from the reactor building to the environment. This is different from the definition used in the LWR severe accident safety basis, which defines the source term as the quantities of radionuclides released to the containment or directly to the environment for events entailing containment bypass. The HTGR definition is judged appropriate for a reactor design that, as discussed in the following section, relies upon the fuel as the principal barrier to release of radionuclides to the environment, even for BDBAs.

\subsubsection{The Principal Barrier to Release of Radionuclides to the Environment}

A specific difference between the LWR safety basis and the HTGR safety basis is the principal barrier to release radionuclides to the environment. In the current LWR designs, the principal barrier to release for severe accidents is the high-pressure, low-leakage containment building. The limiting LBE for the LWR is the loss-of-coolant accident resulting from a breach of the primary coolant system. This postulated accident results in fuel damage and a rapid transient of seconds to minutes in duration characterized by high energy release of the high temperature pressurized water primary coolant. These characteristics require the low-leakage high-pressure containment to absorb the stored energy of the coolant system and contain radionuclides released from the fuel. The high-strength, low-leakage design of the building contains and limits the release of the radionuclides to the environment during and after the accident to meet offsite dose limits.

In contrast, the principal barrier to radionuclide release for postulated LBEs in the HTGR, including BDBAs, is the reactor's TRISO-coated fuel including the fuel particle kernel, which contains the nuclear fuel material, and the multilayered fuel particle coatings that together constitute the TRISO coating system. Based on previous modular HTGR safety analyses, it is expected that there will be no postulated condition of the plant that results in significant fuel particle degradation or any other significant core damage. This is because of the robust nature of the fuel particle, in conjunction with passive ${ }^{e}$ and

e. Passive design features are defined as design features engineered to meet their functional requirements without (a) needing successful operation of systems with mechanical components such as pumps; blowers; heating, ventilation, and air 
inherent ${ }^{\mathrm{f}}$ design characteristics of the reactor that limit excursions in power and fuel temperatures. These characteristics, combined with specifications and quality control on the production of the fuel, assure that most of the fission products will be contained within the fuel under all LBEs. This limits the amount of radionuclides that are transported into the helium and, therefore, the amount that could be released in a postulated breach of the helium pressure boundary.

\subsubsection{Additional Factors Affecting Transport of Radionuclides and Release to the Environment}

As shown in Figure 2-4, there are three other key barriers to fission product transport and radionuclide release to the environment, in addition to the fuel kernel and the coating barriers, that affect calculation of the source terms for the HTGR. These are the core graphite (fuel matrix material and, in the case of the prismatic core, fuel block graphite), helium pressure boundary (primary circuit), and reactor building. The factors affecting the transport of radionuclides through these barriers, as well as from the fuel, include:

- The amount of radionuclides accumulated in the primary circuit during normal operation

- The effect of accident conditions on the integrity of the fuel coatings and on fission product transport rates

- Holdup and release of fission products in the fuel compact or sphere matrix and fuel element graphite

- Plateout and liftoff of radionuclides from surfaces in the primary circuit

- Generation, accumulation, and reentrainment of carbonaceous dust contaminated with radionuclides

- Distribution, condensation, plateout, and settling of radionuclides in the reactor cavity and the other volumes of the reactor building

- The actions of the vent path and ventilation system in the reactor building

- The effects of moisture ingress, should it occur, upon primary circuit pressure, opening of additional release pathways, oxidation and hydrolysis reactions with the core, additional heat sinks and sources, changes in fuel temperature, and changes in release from the fuel

- Gas exchange processes such as those associated with helium boundary depressurization, thermal expansion and contraction of the helium coolant with the core thermal transient, ingress and egress of helium-air mixtures across the helium pressure boundary to the reactor building and across the reactor building boundary with the outside air, and graphite oxidation and its impact on fuel temperatures and releases.

The contributions of each of these factors to the transport of radionuclides released to the environment (source terms) and to the dose calculated at the EAB directly affect the required production quality specifications and performance requirements of the fuel. A principal objective of the development of the source terms for all LBEs is to balance the degree of certainty required to characterize the controlling factors "downstream" of the fuel with the tightness of the specification on production fuel quality and the performance of the fuel under normal and accident conditions.

conditioning or sprays that require an external power source; (b) depending on alternating current of electric power; or (c) relying on operator actions \{DID White Paper\}.

f. Inherent reactor characteristics are those characteristics associated with the reactor concept and the properties of the materials selected for the basic reactor components \{DID White Paper\}. 


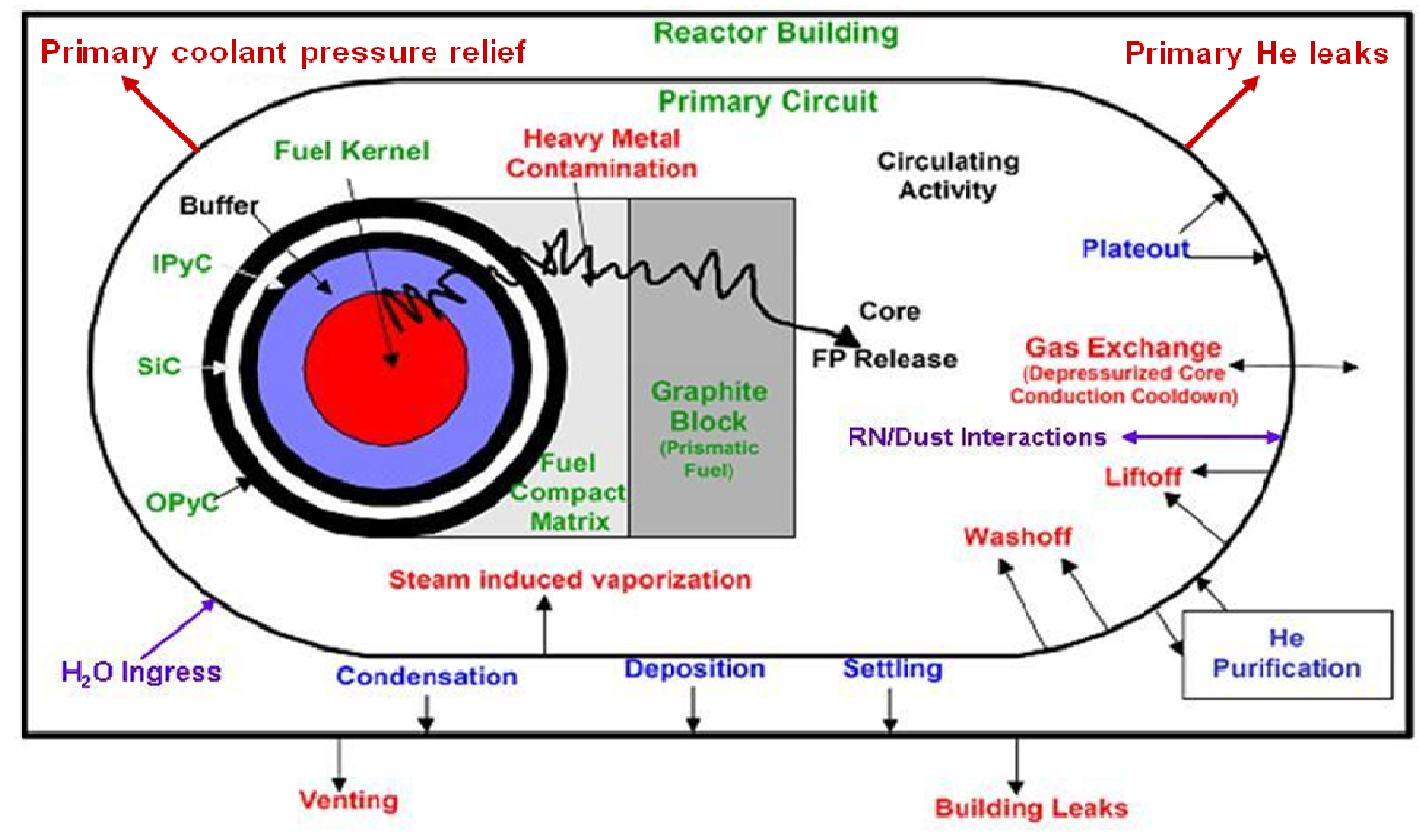

Figure 2-4. HTGR radionuclide retention system.

\subsubsection{Reactor Passive and Inherent Design Characteristics that Contribute to the Safety Basis}

Aside from the fuel, the specific characteristics of HTGRs that contribute to their safety characteristics include:

- A large solid graphite moderator/reflector structure with very high temperature capability. The graphite provides large heat capacity in the core that increases the time constants and reduces the magnitude of core thermal transients. Limiting transients occur over hours and days, not seconds. No fast-acting active safety systems are required to maintain the fuel within design limits.

- A passive heat transfer path from the fuel to the ultimate heat sink (e.g., the reactor cavity cooling system). This heat transfer path through graphite moderator/reflector and through the reactor vessel to the reactor cavity cooling system has the capacity to limit fuel, reactor pressure vessel, and reactor cavity structural concrete temperatures so that degradation of the fuel barrier is limited to acceptable levels and there is no degradation of the core geometry without requiring any active SSCs. No active forced cooling or coolant injection systems are required to maintain acceptable fuel temperatures and core geometry.

- A large negative temperature coefficient that limits reactor power levels to relatively low levels under accident conditions without control rod or reserve shutdown system insertion of negative reactivity.

- A low core power density and high core surface to volume ratio that limits the fuel temperature rise in the most limiting conditions of loss-of-forced cooling and depressurization of the primary circuit.

- A single-phase, chemically inert, neutronically transparent, and low-heat-capacity helium coolant with low stored energy, minimizing the requirement for containment of energy in a postulated breach of the helium pressure boundary.

Based on previous modular HTGR safety analyses, the most important LBEs for which radionuclide release is calculated for the HTGR are expected to include loss-of-forced cooling and helium leaks that 
lead to depressurization of the system. The severity of these events may also be affected by air or water ingress, which can increase heat generation, produce steam and other gases (e.g., $\mathrm{H}_{2}, \mathrm{CO}_{2}$ and/or $\mathrm{CO}$ ), affect the fuel and core graphite structure, and increase the rate of release of some fission products from the fuel. Steps have been taken to prevent ingress of contaminants, and consequences are expected to be acceptable if they occur. Under the most limiting conditions of loss of all active systems (e.g., loss of primary helium circulators, the shutdown cooling system circulator, and reactor cavity active cooling), heat generation in the core is dissipated through the passive heat conduction path to the reactor cavity cooling system. Heat generation is limited by the large negative temperature coefficient of the core, which will drive the power to low levels without the action of control rods or the reserve shutdown system. These fundamental inherent characteristics combine to maintain fuel temperatures within the range required to ensure the integrity of its fission product transport barriers and limit the release of fission products under all postulated accident conditions.

Sections 4 and 5 of this document present detailed discussions of the factors affecting development of the source terms, the ongoing work to provide confidence in the correlations used to define each element used to calculate the source terms, and gaps that need to be filled in planned work.

\subsection{Radionuclide Design Criteria}

Standard design practice in the U.S. HTGR program has been to define a two-tier set of radionuclide design criteria - referred to as "maximum expected" and "design" criteria (or allowable core releases for normal operation and anticipated operational occurrences). This practice has been followed since the design of the Peach Bottom 1 prototype U.S. HTGR up through the commercial gas-turbine modular helium reactor (GT-MHR). The "design" criteria are derived from externally imposed requirements or guidelines, such as site boundary dose limits, occupational exposure limits, Environmental Protection Agency (EPA) Protective Action Guides (PAGs), etc. In principle, any of these radionuclide control requirements or guidelines could be the most constraining for a given reactor design.

After the "design" criteria have been derived from the radionuclide control requirements, the corresponding "maximum expected" criteria are derived by dividing the "design" criteria by a design margin to account for uncertainties in the design methods. This factor is typically a factor of four for the release of fission gases from the core and a factor of 10 for the release of fission metals (e.g., Hanson 2002). The fuel and core are to be designed such that there is at least a $50 \%$ probability that the fission product release will be less than the "maximum expected" criteria and at least a 95\% probability that the release will be less than the "design" criteria. The approach to implementing such radionuclide design criteria is illustrated in Figure 2-5. No particular scale is implied in this figure; it is simply a conceptual illustration of the approach.

In the example given in Figure 2-5, the preliminary design predictions (solid lines) slightly exceed the criteria (triple lines) at the 50\% confidence level; i.e., the nominal (50\% confidence) prediction is slightly higher than the "maximum expected" criterion, but the $95 \%$ confidence prediction meets the "design" criterion, primarily because a large design margin was chosen to accommodate the uncertainties in the current design methods at the preconceptual design stage.

In practice, an iterative procedure is required to develop optimized radionuclide design criteria as the plant design matures during the conceptual, preliminary, and final design phases. With each iteration, the lower level requirements are refined as a result of analyses performed for the reactor SSCs. The goal is to produce an optimum design which meets all the top-level requirements with sufficient, but not excessive, margin. The elements involved in optimizing the core release criteria for a particular plant design can be conveniently categorized as (1) development and optimization of design requirements and subordinate criteria, (2) core and plant performance assessments to determine if the design meets the applicable 
requirements, and (3) technology development and demonstration to validate the design and the underlying design methods and codes.
RADIONUCLIDE
PRELIMINARY DESIGN
FINAL DESIGN
DESIGN CRITERIA
PREDICTIONS
PREDICTIONS

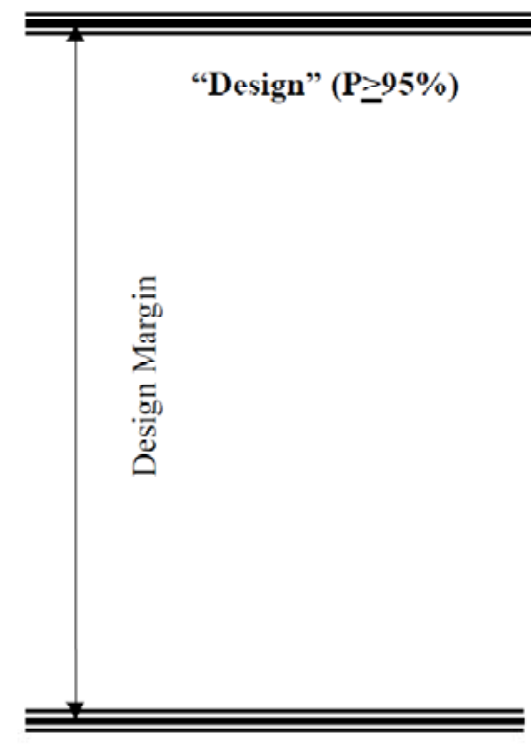

"Maximum Expected" $\left(\mathrm{P}_{\geq} \mathbf{5 0} \%\right)$

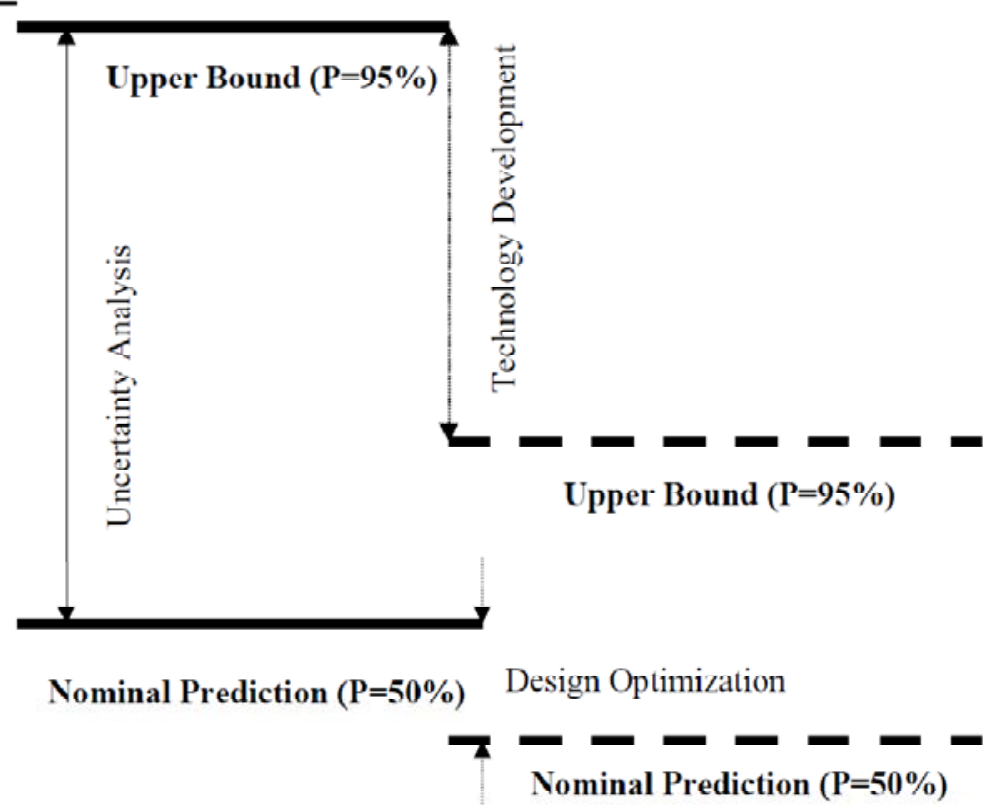

Figure 2-5. Radionuclide design criteria.

The use of a factor of four for the release of fission gases from the core and a factor of 10 for the release of fission metals as the design margin between the maximum expected criteria and design criteria in the U.S. HTGR programs is similar to the practice in the South African Pebble Bed Modular Reactor (PBMR) program. In the PBMR program, a factor of four is used for design margin for noble gases and iodine. This factor is based on a sensitivity analysis of uncertainties in fuel temperature and material properties that affect radionuclide transport within and release from the fuel spheres. A factor of 5 for cesium, 10 for strontium, and 20 for silver is used in the PBMR program for design margin for fission metals. These factors are also based on a sensitivity analysis of uncertainties in factors that affect radionuclide transport (van der Merwe 2004). 


\section{REGULATORY FOUNDATION}

This section identifies currently applicable NRC regulations and guidance and presents related precedents. In applying NRC regulations, which were written primarily to address LWR safety, to modular HTGRs it is necessary, in some cases, to make adjustments for the differences between LWR and HTGR technology. An analysis concerning regulatory gaps will be performed in accordance with the NGNP Licensing Plan (INL 2009) as part of the early dialogue with the NRC. The applicability of the regulations to the HTGR technology will be assessed. This assessment will identify those regulations that directly apply to the HTGR technology, those that partially apply, those that do not apply because of unique LWR-related requirements, and those with applicable intent but need their detailed requirements revised. The assessment will also identify areas where new regulations are needed to address HTGR technology, as applicable.

\subsection{NRC Regulations}

Table 3-1presents various selected NRC regulations, with appropriate adjustments for the differences between LWR and HTGR technology, which are considered relevant to HTGR mechanistic source-term development. Other applicable regulations may exist. The intent of this table is to note those judged to be most clearly applicable.

Table 3-1. NRC regulations relevant to HTGR mechanistic source-term development.

\begin{tabular}{|c|c|c|}
\hline $10 \mathrm{CFR}$ & Statement & Application to HTGR Technology \\
\hline$\S 50.2$, Definitions & $\begin{array}{l}\text { Source term refers to the magnitude and mix of the } \\
\text { radionuclides released from the fuel, expressed as } \\
\text { fractions of the fission product inventory in the fuel, as well } \\
\text { as their physical and chemical form, and the timing of their } \\
\text { release. }\end{array}$ & $\begin{array}{l}\text { The source term for the HTGR is defined as } \\
\text { the quantities, timing, and other } \\
\text { characteristics of radionuclides released } \\
\text { from the reactor building to the environment. } \\
\text { The HTGR definition is judged appropriate } \\
\text { for application for use of the fuel rather than } \\
\text { the reactor building as the primary barrier to } \\
\text { fission product release. }\end{array}$ \\
\hline $\begin{array}{l}\S 52.17 \text {, Contents of } \\
\text { applications; } \\
\text { technical information }\end{array}$ & $\begin{array}{l}\text { (a)(1)(ix) A description and safety assessment of the site } \\
\text { on which a facility is to be located. The assessment must } \\
\text { contain an analysis...fission product release } 1 \text { from the } \\
\text { core into the containment assuming that the facility is } \\
\text { operated at the ultimate power level contemplated. } \\
\text {-------------------- } \\
\text { FN1: The fission product release assumed for this } \\
\text { evaluation should be based upon a major accident, } \\
\text { hypothesized for purposes of site analysis or postulated } \\
\text { from considerations of possible accidental events. Such } \\
\text { accidents have generally been assumed to result in } \\
\text { substantial meltdown of the core with subsequent release } \\
\text { into the containment of appreciable quantities of fission } \\
\text { products. }\end{array}$ & $\begin{array}{l}\text { This is a LWR-specific requirement that has } \\
\text { no direct analogy for HTGRs. In HTGRs the } \\
\text { core does not "melt," and the high } \\
\text { temperature capability of the core materials } \\
\text { is not limiting. For HTGRs, the comparable } \\
\text { events are those in which there is limited, } \\
\text { incremental degradation or failure of fuel } \\
\text { particle coatings, but such events do not } \\
\text { result in loss of coolable geometry. These } \\
\text { comparable events are used in the safety } \\
\text { assessment required under this regulation. }\end{array}$ \\
\hline $\begin{array}{l}\S 52.47 \text {, Contents of } \\
\text { applications; } \\
\text { technical information } \\
\text { (design certification) }\end{array}$ & $\begin{array}{l}\text { (a) The application...must include the following } \\
\text { information: } \\
\text { (1)(iv) The safety features...intended to mitigate the } \\
\text { radiological consequences of accidents. In performing } \\
\text { this assessment, an applicant shall assume a fission } \\
\text { product release from the core into the containment } \\
\text { assuming that the facility is operated at the ultimate } \\
\text { power level contemplated. The applicant shall perform }\end{array}$ & $\begin{array}{l}\text { The safety basis of the HTGR precludes } \\
\text { significant failure or degradation of fuel } \\
\text { particle coatings and, therefore, focuses on } \\
\text { limiting the release of significant amounts of } \\
\text { radioactive material as a result of event } \\
\text { sequences that could occur with this design. } \\
\text { The calculation of the source terms for these } \\
\text { conditions requires validating the }\end{array}$ \\
\hline
\end{tabular}


Table 3-1. (continued).

\begin{tabular}{|c|c|c|}
\hline $10 \mathrm{CFR}$ & Statement & Application to HTGR Technology \\
\hline & $\begin{array}{l}\text { an evaluation and analysis of the postulated fission } \\
\text { product release, using the expected demonstrable } \\
\text { containment leak rate and any fission product cleanup } \\
\text { systems intended to mitigate the consequences of the } \\
\text { accidents... }\end{array}$ & $\begin{array}{l}\text { characteristics and integrity of barriers to } \\
\text { transport and release of radionuclides from } \\
\text { the plant under all normal operating and } \\
\text { accident conditions. Inherent and passive } \\
\text { characteristics of the core and plant design } \\
\text { act to limit power and thermal transients } \\
\text { within the fuel to ensure that fuel integrity is } \\
\text { maintained within assumed limits. The } \\
\text { Chapter } 15 \text { accident analyses will include a } \\
\text { deterministic analysis of the release from the } \\
\text { reactor building for all DBAs to determine the } \\
\text { calculated source term for each event. The } \\
\text { reactor building leak rate and fission product } \\
\text { cleanup systems (if any) will be taken into } \\
\text { account in determining radionuclide release } \\
\text { from the reactor building. }\end{array}$ \\
\hline $\begin{array}{l}\S 52.79 \text {, Contents of } \\
\text { applications; } \\
\text { technical information } \\
\text { in final safety } \\
\text { analysis report }\end{array}$ & $\begin{array}{l}\text { (a) The application must contain a final safety analysis } \\
\text { report that ...shall include the following information: } \\
\text { (1)(vi) ... n performing this assessment, an applicant } \\
\text { shall assume a fission product release from the core } \\
\text { into the containment assuming that the facility is } \\
\text { operated at the ultimate power level contemplated. The } \\
\text { applicant shall perform an evaluation and analysis of } \\
\text { the postulated fission product release, using the } \\
\text { expected demonstrable containment leak rate and any } \\
\text { fission product cleanup systems intended to mitigate the } \\
\text { consequences of the accidents... }\end{array}$ & $\begin{array}{l}\text { The Chapter } 15 \text { accident analyses will } \\
\text { include a deterministic analysis of the } \\
\text { release from the reactor building for all DBAs } \\
\text { to determine the calculated source term for } \\
\text { each event. The reactor building leak rate } \\
\text { and fission product cleanup systems (if any) } \\
\text { will be taken into account in determining } \\
\text { radionuclide release from the reactor } \\
\text { building. }\end{array}$ \\
\hline $\begin{array}{l}\S 52.137, \text { Contents of } \\
\text { applications; } \\
\text { technical information. } \\
\text { (Standard Design } \\
\text { Approval) }\end{array}$ & $\begin{array}{l}\text { (a) The application must contain a final safety analysis } \\
\text { report that...must include the following information: } \\
\text { (2) A description and analysis of the SSCs of the facility, } \\
\text { with emphasis upon performance requirements, the } \\
\text { bases, with technical justification, upon which the } \\
\text { requirements have been established, and the } \\
\text { evaluations required to show that safety functions will } \\
\text { be accomplished. } \\
\text { (iii) The extent to which the reactor incorporates } \\
\text { unique, unusual or enhanced safety features having } \\
\text { a significant bearing on the probability or } \\
\text { consequences of accidental release of radioactive } \\
\text { materials; and } \\
\text { (iv) The safety features that are to be engineered into } \\
\text { the facility and those barriers that must be breached } \\
\text { as a result of an accident before a release of } \\
\text { radioactive material to the environment can occur. } \\
\text { Special attention must be directed to plant design } \\
\text { features intended to mitigate the radiological } \\
\text { consequences of accidents. In performing this } \\
\text { assessment, an applicant shall assume a fission } \\
\text { product release from the core into the containment } \\
\text { assuming that the facility is operated at the ultimate } \\
\text { power level contemplated. The applicant shall } \\
\text { perform an evaluation and analysis of the postulated } \\
\text { fission product release, using the expected }\end{array}$ & $\begin{array}{l}\text { The Chapter } 15 \text { accident analyses will } \\
\text { include a deterministic analysis of the } \\
\text { release from the reactor building for all DBAs } \\
\text { to determine the calculated source term for } \\
\text { each event. The reactor building leak rate } \\
\text { and fission product cleanup systems (if any) } \\
\text { will be taken into account in determining } \\
\text { radionuclide release from the reactor } \\
\text { building. }\end{array}$ \\
\hline
\end{tabular}


Table 3-1. (continued).

\begin{tabular}{|c|c|c|}
\hline 10 CFR & Statement & Application to HTGR Technology \\
\hline & $\begin{array}{l}\text { demonstrable containment leak rate and any fission } \\
\text { product cleanup systems intended to mitigate the } \\
\text { consequences of the accidents... }\end{array}$ & \\
\hline $\begin{array}{l}\S 52.157, \text { Contents of } \\
\text { applications; } \\
\text { technical information } \\
\text { in final safety } \\
\text { analysis report }\end{array}$ & $\begin{array}{l}\text { d) The safety features that are engineered into the reactor } \\
\text { and those barriers that must be breached as a result of an } \\
\text { accident before a release of radioactive material to the } \\
\text { environment can occur. Special attention must be directed } \\
\text { to reactor design features intended to mitigate the } \\
\text { radiological consequences of accidents. In performing this } \\
\text { assessment, an applicant shall assume a fission product } \\
\text { release from the core into the containment assuming that } \\
\text { the facility is operated at the ultimate power level } \\
\text { contemplated. The applicant shall perform an evaluation } \\
\text { and analysis of the postulated fission product release, } \\
\text { using the expected demonstrable containment leak rate } \\
\text { and any fission product cleanup systems intended to } \\
\text { mitigate the consequences of the accidents...to evaluate } \\
\text { the offsite radiological consequences. }\end{array}$ & $\begin{array}{l}\text { The Chapter } 15 \text { accident analyses will } \\
\text { include a deterministic analysis of the } \\
\text { release from the reactor building for all DBAs } \\
\text { to determine the calculated source term for } \\
\text { each event. The reactor building leak rate } \\
\text { and fission product cleanup systems (if any) } \\
\text { will be taken into account in determining } \\
\text { radionuclide release from the reactor } \\
\text { building. }\end{array}$ \\
\hline $\begin{array}{l}\S 100.11, \\
\text { Determination of } \\
\text { exclusion area, low } \\
\text { population zone, } \\
\text { population center } \\
\text { distance }\end{array}$ & $\begin{array}{l}\text { (a) As an aid in evaluating a proposed site, an applicant } \\
\text { should assume a fission produce release from the core, } \\
\text { the expected demonstrable leak rate from the containment } \\
\text { and the meteorological conditions pertinent to his site to } \\
\text { derive an exclusion area, a low population zone and } \\
\text { population center distance. }\end{array}$ & $\begin{array}{l}\text { A mechanistic source term that projects the } \\
\text { radionuclide release to the environment from } \\
\text { the reactor building will be calculated for } \\
\text { each LBE. The dose at the EAB will be } \\
\text { calculated for the source terms and the } \\
\text { appropriate meteorological conditions. The } \\
\text { objective is to limit the dose at the EAB to } \\
\text { values that meet all top-level regulatory } \\
\text { requirements so that the EPZ and EAB are } \\
\text { coincident. }\end{array}$ \\
\hline
\end{tabular}

\subsection{SECY Paper Precedents}

The NRC has released several Commission SECY papers relevant to development and use of a mechanistic source term. In SECY-93-092 (1993), "Issues Pertaining to the Advanced Reactor (PRISM, MHTGR, and Process Inherent Ultimately Safe [PIUS]) and CANDU 3 Designs and Their Relationship to Current Regulatory Requirements," the staff addressed the source term issue for the PRISM, Modular HTGR, PIUS, and the CANDU-3 reactor designs and recommended to the Commission that mechanistic source terms be allowed provided that the:

- Reactor and fuel performance under normal and off-normal operating conditions is sufficiently well understood to permit a mechanistic analysis. Sufficient data should exist on the reactor and fuel performance through the research, development, and testing programs to provide the adequate confidence in the mechanistic approach.

- Transport of fission products can be adequately modeled for all barriers and pathways to the environs, including specific consideration of containment design. The calculations should be as realistic as possible so that the values and limitations of any mechanism or barrier are not obscured.

- Events considered in the analyses to develop the set of source terms for each design are selected to bound severe accidents and design-dependent uncertainties.

The Advisory Committee on Reactor Safeguards (ACRS) agreed with the staff and stated in a letter dated February 19, 1993, to NRC Chairman Selin that "the staff proposal to base the source term on mechanistic analyses appears reasonable, although it is clear that the present data base will need to be 
expanded" and "it will be appropriate for the staff to consider using newer approaches when it develops source terms, and to take specific account of the unique features of each of the reactor types."

In a July 30, 1993, Staff Requirements Memorandum (SRM), the Commission approved the staff's recommendations including its agreement with the ACRS.

There were further regulatory developments between 1993 and 2002 that add to the source term discussion. Although these developments were LWR focused, their regulatory adoption led to NRC's current licensing framework in which mechanistic source terms are used. In SECY-97-171 (1997), "Consideration of Severe Accident Risk in NRC Regulatory Decisions," the staff noted:

During the past 30 years substantial additional information on fission product releases has been developed based on significant severe accident research.

As a result of this research, a revised accident source term has been developed for regulatory applications for future LWRs (NUREG-1465, "Accident Source Terms for Light-Water Nuclear Power Plants," February 1995). Insights from severe accident research on fission product release and transport were used in developing the revised source term. The revised source term is expressed in terms of times and rates of appearance of radioactive fission products into the containment, the types and quantities of the species released, and other important attributes such as the chemical forms of iodine, given a severe core-melt accident. This mechanistic approach provides, for regulatory purposes, a more realistic estimate of the amount of fission products present in the containment from a postulated severe accident than was included in TID-14844. This source term can have implications on issues such as Part 100 reactor siting criteria, equipment qualification, control room habitability, and assessments of severe accident risks in plant environmental impact statements.

SECY-02-0139 (2002), "Plan for Resolving Policy Issues Related to Licensing Non-Light Water Reactor Designs," identified seven reactor licensing policy issues. Issue 5 related to licensing source terms by stating that:

“...future plants, particularly non-LWRs, propose not to use a predetermined source term for assessing the effectiveness of plant mitigation features or site suitability, but rather to use plant specific accident source terms corresponding to each of the AOOs and DBEs defined for the plant. Such an approach puts a burden on the applicant and staff to understand the fission product release characteristics and uncertainties associated with a variety of accident scenarios."

SECY-03-0047 (2003), "Policy Issues Related to Licensing Non-Light Water Reactor Designs," offered staff recommendations on the policy issues discussed in SECY 02-0139 (2002). Issue 5 postulated, "Under what conditions, if any, should scenario-specific accident source terms be used for licensing decisions?" The NRC staff recommended the following action to the Commission:

- "Retain the Commission's guidance contained in the July 30, 1993, SRM that allows the use of scenario specific source terms, provided there is sufficient understanding and assurance of plant and fuel performance and deterministic engineering judgment is used to bound uncertainties."

- "This recommendation will allow credit to be given for the unique aspects of plant design (i.e., performance based) .... Furthermore, this approach is consistent with prior Commission and ACRS views. However, this approach is also dependent upon understanding fuel and fission product behavior under a wide range of scenarios and on ensuring fuel and plant performance is maintained over the life of the plant."

This recommendation acknowledged unique performance aspects of possible plant designs and provided for a probabilistic event identification approach to be considered. Sufficient understanding of 
plant and fuel performance and deterministic engineering judgment would be used to bound uncertainties. In an SRM dated June 26, 2003, the Commission approved the NRC staff recommendation cited in Issue 5 of SECY-03-047 (2003), thereby endorsing consideration of mechanistic scenario-specific source terms for non-LWR licensing decisions.

SECY-05-006 (2005), "Second Status Paper on the Staff's Proposed Regulatory Structure for New Plant Licensing and Update on Policy Issues Related to New Plant Licensing," which has not yet been approved by the Commission, provides additional information regarding NRC staff thinking on scenariospecific source terms. It discussed how the staff intends to incorporate, among other topics, the use of scenario-specific source terms into the proposed regulatory structure for new plant licensing. This paper was written in response to the June 26, 2003, SRM. With regard to source terms, the staff indicated that it used a flexible, performance-based approach to establish scenario-specific licensing source terms. The key features of this approach are as follows:

- Scenarios are to be selected from a design-specific probabilistic risk analysis

- Source term calculations are based on verified analytical tools

- Source terms for compliance should be $95 \%$ confidence level values based on best-estimate calculations

- Source terms for emergency preparedness should be mean values based on best-estimate calculations

- Source terms for licensing decisions should reflect scenario-specific timing, form, and magnitude of the release.

This approach puts the burden on the applicant to develop the technical basis for the proposed source terms.

\subsection{Regulatory Guidance}

\subsubsection{NRC Standard Review Plan for LWRs}

NUREG-0800 (1987, Revised 2007) sets forth Standard Review Plans (SRPs) to guide NRC reviewers during LWR design evaluations. Compliance with NUREG-0800 is not required of applicants or licensees. For instance, SRP 12.2, "Radiation Sources," requires NRC staff to review facility safety information and assess it against applicable requirements and guidance. Information must be reviewed concerning radiation sources during normal operations, anticipated operational occurrences, and accident conditions. Descriptions must include isotopic composition, source strength, geometry, and the basis for these values as well as anticipated release fractions and measures that mitigate releases to the environment. Furthermore, Section II of SRP 12.2, "SRP Acceptance Criteria," specifies that:

... an applicant is required to identify differences between the design features, analytical techniques, and procedural measures proposed for its facility and the SRP acceptance criteria and evaluate how the proposed alternatives to the SRP acceptance criteria provide acceptable methods of compliance with NRC regulations.

Certain HTGR design aspects depart from the LWR-based criteria currently contained in SRP 12.2. Therefore, alternative information must be provided to adequately demonstrate compliance with NRC rules. The content and structure of this alternative information will be addressed in the COL Application Content Guide, as discussed in the NGNP Licensing Plan (INL 2009). 


\subsubsection{Regulatory Guides}

The following regulatory guidance relates to NRC's review and development of LWR source terms and has been examined for potential applicability to mechanistic source terms for the HTGR.

Radiological DBAs for LWRs are currently analyzed based upon preestablished deterministic source term releases into the containment. This DBA source term is described in Atomic Energy Commission Document TID-14844 (DiNunno et al. 1962) and NRC NUREG-1465 (1995). TID-14844, issued in 1962, specified a nonmechanistic source term which was based on experiments in the late 1950s involving heated, irradiated $\mathrm{UO}_{2}$ fuel pellets. NUREG-1465, issued in 1995, is a more mechanistic portrayal of fission product release to the containment, which was based on the understanding of severe accidents that evolved subsequent to the TMI-2 accident. NUREG-1465 indicates that the release fractions in the report are intended to be representative or typical of those associated with low pressure core damage events. In the preface to NUREG-1465, it is stated:

"Source terms for future reactors may differ from those presented in this report, which are based upon insights derived from current generation light-water reactors. An applicant may propose changes in source term parameters (timing, release magnitude, and chemical form) from those contained in this report, based upon and justified by design specific features."

Guidance related to TID-14844 compliance for holders of operating licenses issued prior to January 10, 1997, are set forth in Regulatory Guides 1.3 (boiling water reactors) and 1.4 (pressurized water reactors), while Regulatory Guide 1.183 applies to LWR applicants or license holders issued thereafter.

10 CFR $\$ 50.67$ and Regulatory Guide 1.183 provide for the development of an NRC-acceptable alternative source term (AST) to those provided in NUREG-1465 (1995). (Implementation of an AST under this guide assumes use of an LWR and is mentioned in NUREG-0800 SRP Section 15.0.1, "Radiological Consequence Analyses Using Alternative Source Terms.") The guidance provides insight on the meaning of "mechanistic source term" and related NRC expectations. Regulatory Guide 1.183 expects an acceptable AST to have the following attributes:

- The AST must be based on major accidents, hypothesized for the purposes of design analyses or consideration of possible accidental events that could result in hazards not exceeded by those from other accidents considered credible. The AST must address events that involve a substantial meltdown of the core with the subsequent release of appreciable quantities of fission products.

- The AST must be expressed in terms of times and rates of appearance of radioactive fission products released into containment, the types and quantities of the radioactive species released, and the chemical forms of iodine released.

- The AST must not be based on a single accident scenario but instead represent a spectrum of credible severe accident events. Risk insights may be used not to select a single risk significant accident but rather to establish the range of events to be considered. Relevant insights from applicable severe accident research on the phenomenology of fission product release and transport behavior may be considered.

- The AST must have a defensible technical basis supported by sufficient experimental and empirical data, be verified and validated, and be documented in a suitable form that facilitates public review and discourse.

- The AST must be peer reviewed by appropriately qualified subject matter experts. Peer review comments and their resolution should be part of the documentation supporting the AST. 
There are specific aspects of these expectations that are not directly applicable to the HTGR technology (e.g., "meltdown of the core with the subsequent release of appreciable quantities of fission products"). However, the approach to calculate event-specific mechanistic source terms for HTGRs will meet the intent of these expectations.

\subsection{Additional Guidance}

The American Nuclear Society draft standard, "Nuclear Safety Criteria and Safety Design Process for Modular Helium-Cooled Reactor Plants" (ANS-53.1 2009), released for public comment in early 2009, specified that event-specific source terms should include contributions from circulating activity, liftoff of plateout and dust, and radionuclide release from fuel during events. Radionuclide transport is to be calculated with consideration of radionuclide deposition and desorption on primary circuit surfaces and other plant equipment and structures. All radionuclide source-term calculations must use qualified methods. The draft standard cites NRC Regulatory Guide 1.203 as one approach for qualifying methods.

\subsection{U.S. HTGR Precedents}

\subsubsection{Peach Bottom Final Hazards Summary Report}

An HTGR construction permit was issued to Philadelphia Electric Company for the Peach Bottom Unit 1 plant in 1962. This 40 MW(e) plant operated from 1967 to 1974. The Peach Bottom plant Class 104 operating license was granted based in part on the final hazards summary report (Philadelphia Electric Company 1964). The Peach Bottom final hazards summary report used a conservative source term based on mechanistic release phenomena and preserved the time-dependent nature of HTGR fuel release during a BDBA.

\subsubsection{Fort St. Vrain Final Safety Analysis Report}

The Fort St. Vrain (FSV) Nuclear Generating Station was a prismatic fuel HTGR that generated 842 MWth to achieve a net output of 330 MW(e). FSV operated from 1974 to 1989 and was licensed using a deterministic source term based on TID-14844 (DiNunno et al. 1962). Two DBAs were presented in the FSV final safety analysis report (Public Service Company of Colorado 1991) and represented an early effort to use a more mechanistic source term approach for a medium-sized HTGR. The applicant did not consider TID-14844 values to be applicable to the HTGR system, but a mechanistic source term was compared to TID-14844 assumptions to demonstrate the relative safety of the HTGR.

\subsubsection{Other HTGR Initiatives}

\subsubsection{GASSAR}

GASSAR-6 was General Atomics' standard safety analysis report for a 6-loop HTGR rated at $3000 \mathrm{MWth} / 1160 \mathrm{MW}(\mathrm{e})$. The design closely approximated that considered by Philadelphia Electric Company for the Fulton Station. It was docketed by NRC for review as a standard plant (General Atomics 1975). The maximum hypothetical fission product release employed a nonmechanistic source term in that it did not consider any credible sequence of events. However, final safety analysis report maximum hypothetical fission product release employed mechanistic assumptions that included fundamental physical principles, empirical correlations, and primary system properties relevant to release processes. NRC issued an interim safety evaluation report documenting the status of the GASSAR-6 review (NRC 1977). The Fulton preliminary safety analysis report was reviewed as far as completion of the NRC safety evaluation report and ACRS review letter. These reviews identified a generic HTGR safety issue involving the source term. Fuel performance data and plateout information for a large HTGR was 
considered inadequate to determine an accurate model of fission product release as required by 10 CFR $\S 100$. In review of Fulton, the NRC staff employed a very conservative fission product release model to circumvent these shortcomings.

\subsubsection{Modular HTGR}

A commercial modular HTGR preliminary safety information document (PSID) (Stone \& Webster Engineering Corp. 1992) was submitted to the NRC in September 1986 by DOE. A key objective of the PSID was to examine the use of mechanistic (scenario-specific) source terms in lieu of the nonmechanistic source terms documented in TID-14844. Preliminary NRC review of the PSID was documented in a draft preapplication safety evaluation report, (NUREG-1338 1989); the final draft preapplication safety evaluation report was released in December 1995 (NUREG-1338 1995).

NUREG-1338 identified a policy issue concerning modular HTGR source-term calculation. This was discussed in SECY-88-203 (1988). It was recognized that a reactor design that considered a mechanistic source term was a major departure from both LWRs and earlier HTGR designs, and this was considered to be a critical issue. The final preapplication safety evaluation report defined the mechanistic source term as a licensability issue (where the design departs significantly from what NRC has accepted in the past or where changes to the design to resolve a staff concern may fundamentally alter the proposed design) and stated that source term had to be adequately addressed in applications for design approval, the preliminary design approvals, final design approvals, or standard plant design certifications under 10 CFR §52.

\subsubsection{Pebble Bed Reactors}

There have been no PBMR license applications submitted to the NRC, but there have been several preapplication interactions with the NRC on pebble bed designs. PBMR is a modular HTGR design dating back to the 1960s. The prototype AVR research reactor in Germany operated 21 years to test pebble bed reactor technology. The technology was also used in the German Thorium High Temperature Reactor (THTR) project and was used in the design of the HTR Modul facility in Germany. The technology was further advanced to a power plant concept by a South African company (PBMR [Pty] Ltd.), the Demonstration Power Plant (DPP). The technology is used in China's HTR-10 research reactor.

In 2000, Exelon Generation Company began preapplication interactions with NRC on the feasibility of licensing a PBMR design under the combined licensing provisions of $10 \mathrm{CFR} \S 52$. Preparation for the review resulted in SECY-01-0070 (2001), "Plan for Preapplication Activities on the Pebble Bed Modular Reactor (PBMR)." Attachment 2 of SECY-01-0070 outlined proposed PBMR preapplication activities and, in the section titled "Regulatory Requirements, Safety, and Policy Issues," the plan stated that:

- An important output from the preapplication interactions with Exelon will be the identification of applicable requirements, safety, and policy issues. This will involve looking at the requirements in 10 CFR (and their supporting regulatory guides) and identifying those that are unique to LWRs (and thus not applicable to the PBMR), as well as looking at the PBMR design and the technology and safety issues and identifying unique aspects that are not covered by current requirements.

- It is expected that the technology, safety and regulatory assessments will lead to the identification of certain safety and policy issues that would need to be resolved in order to proceed with an actual licensing review. It is likely that the issues that stem from the preapplication activities will include... what accidents should the plant be designed for, .... an acceptable approach to the source term [and] a combination of traditional engineering and a risk informed approach to addressing the issues would be utilized.

This document was approved by the Commission in a SRM dated June 19, 2001. 
SECY-02-0076 (2002), "Semi-Annual Update of the Future Licensing and Inspection Readiness Assessment," described Exelon's proposed licensing approach. Exelon proposed conformance with current regulations but recognized that many of the regulatory requirements were based on LWR technology. A risk-informed process would be employed to define plant design events, acceptance criteria, and SSCs. In its preliminary evaluation, NRC staff concluded that the proposed licensing approach, if adequately implemented, was a reasonable process for ensuring that the Commission's regulations would be met and for identifying PBMR-specific regulatory requirements. The staff had planned to engage the Commission on policy issues associated with the PBMR design, including application of a mechanistic source term. However, Exelon halted the PBMR project in April 2002. Preapplication reviews and related NRC policy resolutions activities were closed by September 2002.

More recently, PBMR (Pty) Ltd. submitted a series of PBMR preapplication papers to the NRC for review in support of their design certification process. In their letter to the NRC (PBMR 2006), PBMR highlighted:

...the importance of establishing a mechanistic source term as part of a risk informed, performance based application. The discussion of how the mechanistic source term will be developed is critical to the PBMR design, and the current deterministic approach for light water reactors (LWRs) is not appropriate for the PBMR.

Evolving acceptance of mechanistic source term use in licensing decisions for non-LWRs was documented in Attachment 5 of SECY 03-047 (2003):

Using mechanistic source terms based on a selection of design basis events and a good foundation of plant-specific knowledge, such as fuel behavior and core response under off normal conditions, has been the trend for advanced non-LWRs worldwide. The HTR-10 in China used a source term based on a mechanistic approach in which severe core damage was not arbitrarily postulated for the siting evaluation; instead the radiation release was calculated specifically for the individual accidents leading to the largest release of radionuclides from the fuel elements. Both Exelon and PMBR (Pty) Ltd. proposed mechanistic source terms based on design basis events and predictions of fuel behavior for the pebble bed modular reactor (PBMR). 


\section{NGNP APPROACH FOR MECHANISTIC SOURCE TERMS}

\subsection{Factors Affecting Source Term Calculation}

Several factors need to be considered in a mechanistic definition of event-specific source terms for the HTGR technology. As these are defined and characterized, the influence of each on the calculated dose is established. This permits developing a target for each element in the source term calculation to meet the safety goals of the project. The development of these targets and the degree to which each element of the source term calculation must be characterized are addressed in several steps:

1. Establish the top-level radionuclide control requirements to ensure the health and safety of the public and plant workers and to protect the environment. (Representative values for these requirements are presented in Section 4.2 of this white paper to put this aspect of developing the mechanistic source term in perspective. These were established in prior development of HTGR technology. The LBE white paper, which will be developed and submitted by the NGNP Project at a later date, will discuss these requirements.)

2. Identify LBEs for which plant conditions and source terms are to be calculated and compared with the goals. (Examples from prior development of LBEs for HTGRs are provided for perspective in this white paper. A separate paper describing the development of LBEs will be prepared and submitted by the NGNP Project at a later date.)

3. Identify and characterize the factors affecting radionuclide generation and transport for this reactor technology.

4. Scope the influence of each factor on the magnitude of the source terms and establish the principal parameters needed to characterize the effect of these factors on the generation and transport of radionuclides for the LBEs.

5. Establish a target for each factor to achieve the goal for each event.

6. Calculate source terms and dose rates based on the current understanding of generation and transport phenomena for the LBEs and compare with top-level radionuclide control requirements (not included within the scope of this white paper).

7. As needed to support meeting the top-level radionuclide control requirements, identify how well each factor is currently characterized to validate its target in establishing the source terms and, where the current characterization is deficient, define the gaps between what is needed and what is known.

8. Develop and complete analytic and testing programs to fill those gaps, if needed.

9. Calculate source terms and dose rates again based on the more fully characterized and validated generation and transport phenomena for the LBEs and compare with top-level radionuclide control requirements (not included within the scope of this white paper).

This process may require iteration if calculated dose values do not meet the goals of the project or the elements need to be retargeted.

The following sections step through this process: Section 4 carries the discussion through characterization of the gaps, and Section 5 discusses the analytic and testing programs that are in place or planned to close the gaps.

\subsection{NGNP Top-Level Radionuclide Control Requirements}

Stringent, top-level radionuclide control requirements are anticipated for modular HTGRs. The objective of setting the top-level radionuclide control requirements is to limit calculated dose under all 
LBEs so that regulatory requirements for protection of the health and safety of the public and protection of the environment are met at an EAB that is no more than a few hundred meters from the reactor (e.g., 400 to 425 meters). Limits on radionuclide release from the reactor building that are consistent with these top-level radionuclide control requirements are needed to establish the target values for all of the barriers to radionuclide release and ultimately to establish allowable in-service fuel failure and as-manufactured fuel quality requirements (e.g., allowable heavy metal contamination, $\mathrm{SiC}$ coating defects, etc.). The key top-level radionuclide control requirements expected to be imposed for the NGNP Project are listed in Table 4-1.

Table 4-1. Key top-level radionuclide control requirements.

\begin{tabular}{|l|l|}
\hline \multicolumn{2}{|l|}{ Top Level Regulatory Requirements } \\
\hline 1 & $\begin{array}{c}10 \text { CFR } 50, \text { Appendix I, Limits for Radionuclides in Plant Effluents: } \\
\text { a. Whole Body Dose } \leq 5 \text { mrem/yr } \\
\text { b. Thyroid Dose } \leq 15 \text { mrem/yr }\end{array}$ \\
\hline 2 & $\begin{array}{l}10 \text { CFR } 20 \text { Subpart C Occupational Dose Limits: } \\
\text { a. Total effiective dose equivalent (TEDE) } \leq 5 \text { rem } \\
\text { b. Organ Dose } \leq 50 \text { rem }\end{array}$ \\
\hline 3 & $\begin{array}{l}10 \text { CFR } 20 \text { Subpart D Public Dose Limits: } \\
\text { a. Annual TEDE } \leq 0.1 \text { rem } \\
\text { b. Hourly External Dose } \leq 0.002 \text { rem }\end{array}$ \\
\hline 5 & $\begin{array}{l}40 \text { CFR } 190 \text { Subpart B Environmental Standards: } \\
\text { a. Whole Body } \leq 25 \text { mrem } \\
\text { b. Thyroid Dose } \leq 75 \text { mrem }\end{array}$ \\
\hline 6 & $\begin{array}{c}10 \text { CFR } 52.47 \text { Offsite Dose Limits for LBEs: } \\
\text { a. TEDE } \leq 25 \text { rem for } 2 \text { hours at the EAB } \\
\text { b. TEDE } \leq 25 \text { rem for } 30 \text { days at the LPZ boundary }\end{array}$ \\
\hline 7 & $\begin{array}{c}\text { EPA PAGs for Radioactive Release for Public Sheltering \& Evacuation (EPA 1992): } \\
\text { a. TEDE } \leq 1 \text { rem } \\
\text { b. Thyroid Dose } \leq 5 \text { rem }\end{array}$ \\
\hline NRC Safety Risk Limits (NRC 1986)
\end{tabular}

\begin{tabular}{|l|l|}
\hline \multicolumn{2}{|l|}{ User Requirements } \\
\hline 1 & $\begin{array}{c}\text { Occupational Exposures } \leq 10 \% \text { of } 10 \text { CFR } 20 \text { Limits } \\
\text { a. TEDE } \leq 0.5 \text { rem/yr } \\
\text { b. Organ Dose } \leq 5 \text { rem/yr }\end{array}$ \\
\hline 2 & Top Level Regulatory Criteria, including PAGs at the EAB for all events with a frequency $\geq 5 \times 10^{-7} / \mathrm{yr}$ \\
\hline
\end{tabular}

Based on previous work for the modular HTGR, it is expected that meeting the EPA PAG limits at the EAB will likely be the most restrictive requirement for setting fuel performance and quality requirements for the HTGR. Meeting the PAGs at a 425-m EAB was determined to be the bounding radionuclide control requirement for the earlier 350 MWth steam cycle modular HTGR. In the 1992 version of the PAGs, the total effective dose equivalent (TEDE) dose protocol ${ }^{\mathrm{g}}$ was used instead of the earlier whole-body dose protocol. The $1992 \mathrm{PAG}$ also includes a 5-rem thyroid dose limit to preclude the need for public sheltering, and this 5-rem thyroid dose limit proved more constraining than the 1-rem TEDE limit.

g. The TEDE dose is the sum of the deep dose equivalent for external exposures and the committed effective dose equivalent for internal exposures. 
The second most constraining, top-level radionuclide control requirement is expected to limit the occupational exposure to $\leq 10 \%$ of 10 CFR 20 . Typically, occupational exposures result primarily from operations and maintenance activities, especially in-service inspection, during routine plant operation. Plateout activity throughout the primary circuit, especially on the steam generator of a steam cycle modular HTGR, is expected to be a dominant source of occupational exposure. Based on previous occupational exposure assessments and engineering judgment, it was projected that the $\leq 10 \%$ of the 10 CFR 20 goal would be met if the gamma radiation fields around the primary circuit caused by fission product plateout were limited to $\leq 10 \mathrm{mR} / \mathrm{hr}$ for scheduled maintenance activities (e.g., circulator inservice inspection) and to $\leq 100 \mathrm{mR} / \mathrm{hr}$ for unscheduled maintenance activities (e.g., steam generator tube plugging). These limits on gamma dose rates were in turn used to set limits on primary circuit plateout (in particular, limits on Cs-137 and Ag-110m plateout), as in Section 2.4 on radiological design criteria.

\subsection{Licensing Basis Events}

Accident selection plays a lead role in the use of mechanistic source terms because it defines the specific scenarios and associated release mechanisms used to assess the source terms. As asked in SECY-88-203 (1988), "What range of accidents need to be considered for advanced reactors to provide a basis for selecting a mechanistic source term and for judging the adequacy of containment and offsite emergency planning?" An NGNP Project white paper on LBE selection will be submitted in the future to address this question. This paper is anticipated to cite a methodology similar to that discussed in sections of draft American Nuclear Society (ANS) standard 53.1 (2009).

Subjects of other future white papers will include the characterization of LBE frequency and consequence, including uncertainty bounds using probabilistic risk analyses, selecting the classification of the SSCs, and formulating the deterministic accident analyses of Chapter 15 of the safety analysis report.

\subsection{Radionuclide Transport and Retention in the HTGR}

A significant amount of investigation has been performed domestically and internationally to characterize the generation, transport, and retention of fission product radionuclides in HTGRs. This section provides a summary of how this work is translated into calculation of radionuclide transport and retention in the HTGR to support the source term calculation. A more detailed discussion of the work performed to date and existing data is provided in Appendix C.

The phenomena described in this section and in Appendix $\mathrm{C}$ are those that need to be modeled to calculate the mechanistic source terms. The following five barriers to fission product radionuclide release are reviewed:

1. Fuel particle kernel

2. Silicon carbide and pyrocarbon coatings of the fuel particle

3. Fuel matrix and fuel element graphite

4. Helium pressure boundary (primary circuit)

5. Reactor building.

Reference is made to Figure 2-4, which illustrates the HTGR fission product retention system.

The most important consideration in predicting the radionuclide release rates from an HTGR core is to predict the in-service performance of the TRISO-coated fuel particles. Though the fuel particle is an effective principal barrier to radionuclide release and may in some cases be the only barrier needed to meet the top-level radionuclide control requirements, it is inconsistent with the practice of defense-in- 
depth to rely exclusively on the fuel particles for radionuclide containment. The effectiveness of the other radionuclide release barriers in the radionuclide retention system therefore needs to be quantified.

The radionuclides of interest in HTGR design and safety analysis can be broken into classifications for analysis purposes. The radionuclides within a classification exhibit similar in-core and ex-core behavior for the purpose of radionuclide transport modeling. Table 4-2 summarizes the radionuclide classifications and key behavior characteristics outside of the fuel kernel. The behavior of each of the classes of radionuclides of interest in Table 4-2 is modeled by fission product transport codes, examples of which are discussed in Section 4.5 and Appendices D and $\mathrm{E}$ of this paper. There is significant retention of the fission products in the kernel itself. The fuel kernel and the SiC coatings are the major barriers to fission product release from the fuel particle.

Table 4-2. Classes of radionuclides of interest for HTGR design.

\begin{tabular}{|l|l|l|l|l|}
\hline $\begin{array}{c}\text { Radionuclide } \\
\text { Class }\end{array}$ & $\begin{array}{c}\text { Key } \\
\text { Nuclide }\end{array}$ & Form in Fuel & \multicolumn{1}{c|}{$\begin{array}{c}\text { Principal } \\
\text { In-Core Behavior }\end{array}$} & $\begin{array}{c}\text { Principal } \\
\text { Ex-Core Behavior }\end{array}$ \\
\hline Tritium & H-3 & Element (gas) & $\begin{array}{l}\text { Permeates intact SiC; sorbs on core } \\
\text { graphite }\end{array}$ & Permeates through heat exchangers \\
\hline Noble gases & Xe-133 & Element (gas) & Retained by PyC/SiC & Removed by helium purification system \\
\hline Halogens & I-131 & Element (gas) & Retained by PyC/SiC & Deposits on colder metals \\
\hline Alkali metals & Cs-137 & Oxide-element & $\begin{array}{l}\text { Retained by SiC; some matrix/graphite } \\
\text { retention }\end{array}$ & Deposits on metals/dust \\
\hline Tellurium group & Te-132 & Complex & Retained by PyC/SiC & Deposits on metals/dust \\
\hline Alkaline earths & Sr-90 & Oxide-carbide & High matrix/graphite retention & Deposits on metals/dust \\
\hline Noble metals & Ag-110m & Element & Permeates intact SiC & Deposits on metals \\
\hline Lanthanides & La-140 & Oxide & High matrix/graphite retention & Deposits on metals/dust \\
\hline Actinides & Pu-239 & Oxide-carbide & Quantitative matrix/graphite retention & Retained in core \\
\hline
\end{tabular}

The following section discusses the approach to develop source terms for the HTGR technology independent of the reactor design. The development of the source terms is fundamentally similar in approach for the pebble bed and prismatic block reactor designs. The calculation details are different because of differences in design service conditions and the difference in the spherical and graphite block configurations of the fuel elements. The specific source term calculations will be developed as part of the license application process for each design.

\subsubsection{Radionuclide Behavior During Normal Operation}

Figure 4-1 shows the relationships among the several elements that affect radionuclide behavior and distribution in the primary circuit during normal operations (upper section of the figure) and elements that affect radionuclide behavior in the reactor building and release to the environment during LBEs (lower section of the figure, which illustrates a depressurization event as an example).

After some period of normal operation, steady-state distributions of most of the species of radionuclides generated by fission (other than long-lived radionuclides such as Cs-137 and Sr-90) will be established in the primary circuit. The amount of each species present in the coolant depends on the release of that species from the fuel, radionuclide half life, adsorption of certain species of radionuclides in the fuel and core graphite and on graphitic dust, plateout of certain species on primary circuit components, drop out of dust in areas of low velocity, and performance of the helium purification system (HPS). The rate of release of each species of the radionuclides from the fuel particles during normal operation is primarily dependent on the initial fuel quality and the fuel service conditions. The initial fuel 


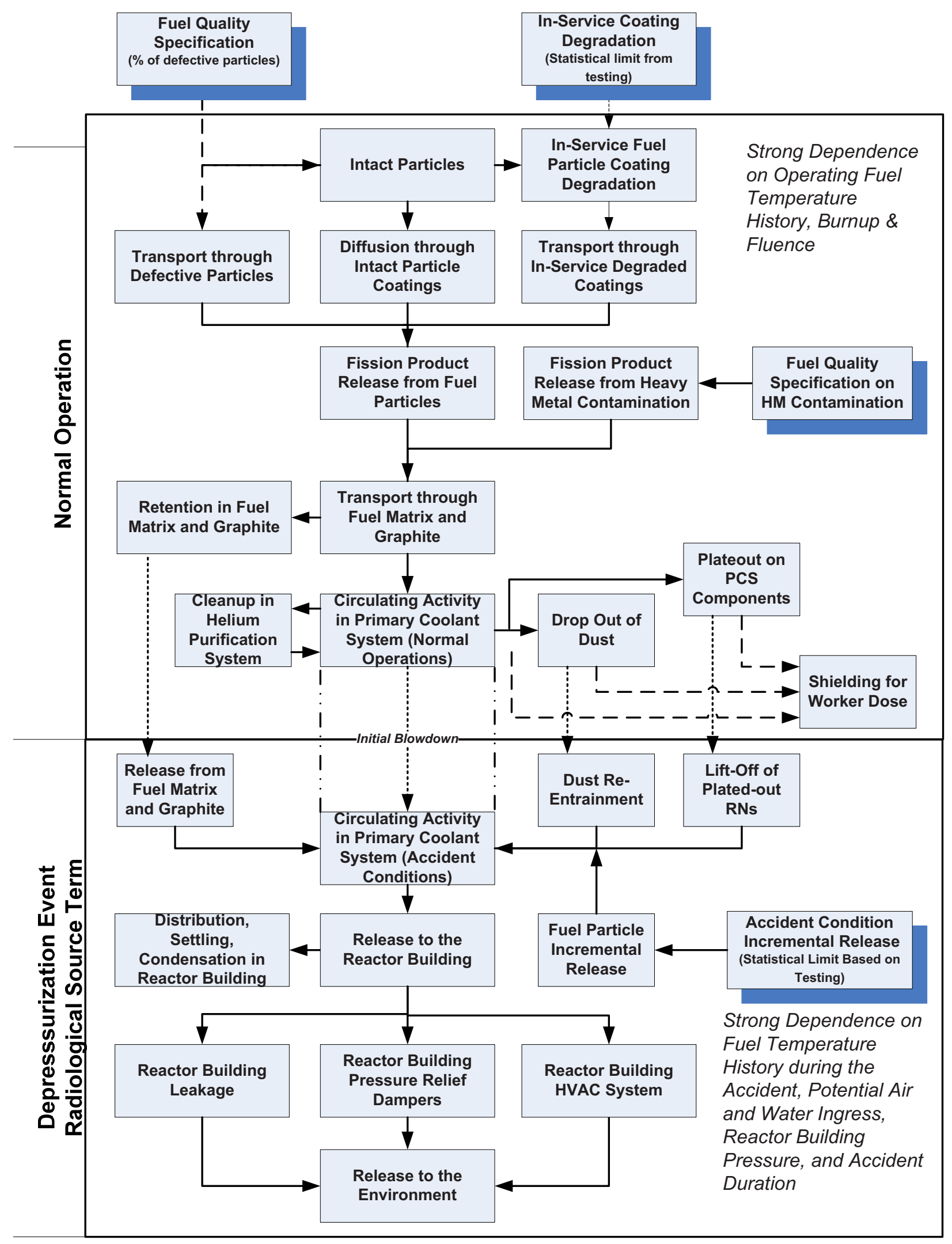

Figure 4-1. HTGR source-term elements. 
quality and in-service failure specifications are used to determine the population of initially defective particles, intact particles, and those assumed to fail in-service.

Even though a very limited amount of in-service failure is anticipated during normal operation because only a finite population can be irradiated during fuel qualification, there will be a statistical limit for in-service fuel failure that is used for design purposes. Table 4-3 presents approximate typical values for initial fuel quality and in-service failure fractions for pebble bed and prismatic HTGRs based on several earlier analyses. The values differ for the two designs because of minor differences in normal operating conditions and time-temperature response of the core during accident events. These values determine the size of particle populations that must be tested under normal and accident conditions to demonstrate that the fuel will perform as anticipated.

Table 4-3. Typical fuel quality and performance values.

\begin{tabular}{|l|c|c|}
\hline \multicolumn{1}{|c|}{ Parameter } & $\begin{array}{c}\text { Allowable Core Average Fraction } \\
(\geq 95 \% \text { Confidence })\end{array}$ & $\begin{array}{c}\text { Allowable Core Average Fraction } \\
(\geq 95 \% \text { Confidence })\end{array}$ \\
\cline { 2 - 3 } & Prismatic & Pebble Bed \\
\hline $\begin{array}{l}\text { Fuel Qualityi } \\
\text { Heavy Metal Contamination } \\
\text { SiC Defect Fraction }\end{array}$ & $\sim 2 \times 10-5$ & $\sim 6 \times 10-5$ \\
\hline In-service Fuel Failure during Normal Operation & $\sim 1 \times 10-4$ & - \\
\hline Incremental Fuel Failure during Accident Conditions & $\sim 2 \times 10-4$ & $\sim 5 \times 10-5$ \\
\hline \multicolumn{2}{|l}{} & $\sim 6 \times 10-4$ \\
\hline i $\quad \begin{array}{l}\text { Fuel quality for a pebble bed HTGR is defined as the sum of heavy metal contamination and SiC defects. In the prismatic HTGR these } \\
\text { specifications are determined separately. }\end{array}$
\end{tabular}

As-manufactured heavy metal contamination (heavy metal outside the intact coated particles) is not a factor affected by in-service conditions, but it is important with respect to fission product release. It is an extreme case of as-manufactured coating defects whereby trace amounts of heavy metal are not encapsulated by any intact coating layers, including cases in which heavy metal contamination is contained in the fuel matrix material (analogous to "tramp uranium" in LWR fuel). Modern fuel-product specifications only allow small fractions of heavy metal contamination $\left(\sim 10^{-5}\right.$ is typical), but it is still an important source of fission product release.

The initially defective particles and those assumed to fail in service will release fission gases and metals. Releases from defective particles are strong functions of the nature of the defect, temperature, burnup, and time. For example, particles with defective $\mathrm{SiC}$ will release $\mathrm{Cs}$ but not fission gases if either of the PyC layers is intact. Based on the available experience with transport of fission products in the TRISO coating layers, except for tritium and silver, diffusion through intact particles is not expected during normal operation if peak fuel temperatures remain below $1250^{\circ} \mathrm{C}$ for the residence time of the fuel (assumed to be 3 years). (Fission product transport code models include the behavior of those fission products that can be released from intact particles.) The graphitic materials (matrix and fuel element graphite) do not retain fission gases and iodine, but experience indicates that fission metals like strontium, europium, and to a lesser extent cesium, are strongly retained in these materials. Retention in the graphitic materials is a strong function of temperature and also fast fluence.

The fission gases, iodine, and the small fraction of fission metals that permeate through the graphite are then released to the reactor coolant system. The helium purification system, which draws a small fraction of coolant upon each pass in the reactor, will reduce the concentrations of some of the fission products. Plateout of the condensable fission products on primary system surfaces is also expected when temperatures are low enough. In an HTGR design with high coolant inlet and outlet temperature (e.g., 
reactor outlet temperatures of $900-950^{\circ} \mathrm{C}$ ), there will be less deposition of iodine than in designs with lower temperatures (e.g., reactor outlet temperatures of $700-800^{\circ} \mathrm{C}$ ), and this will result in higher iodine circulating inventories available for release upon a depressurization. Plateout is a function of the partial pressure of the fission product of interest, the local temperature, chemistry of the coolant, and surface conditions of the metallic alloy used in the coolant system.

Graphite dust in the primary circuit will also adsorb certain fission products. The dust can drop out and accumulate in low velocity areas, contributing to worker dose and providing a potential additional source of activity in the helium if the dust accumulation becomes reentrained. Eventually, during plant operation, a quasi-steady state will develop between the inventory in the purification system, the plateout inventory in the coolant system, and the circulating activity. Because of the strong influence of the operating conditions (local burnup, temperature, and fluence) on the fission product release from and transport behavior in the fuel element, computer codes are used with detailed nodalization of the core and the primary circuit to establish the normal operation radionuclide distribution in the primary circuit, which is used to evaluate worker doses during operation and maintenance and compliance with relevant regulatory requirements.

The steady-state radionuclide concentrations in the primary circuit, the radionuclides plated out on primary circuit components, and those accumulated on dust in the system form an initial source of radionuclide release to the reactor building in a depressurization event. The next section discusses the elements that affect the development of the radiological source terms under these conditions as depicted in the lower section of Figure 4-1.

\subsubsection{Accident Conditions}

The lower section of Figure 4-1 describes the relationships among the several elements of the source term under a helium boundary depressurization event. A depressurization event is illustrated in the figure because, based on previous analyses of modular HTGRs, it is expected to be an important event with regard to offsite dose. There are two phases of interest in a depressurization event: the initial blowdown (Phase 1) and the subsequent core heatup (Phase 2).

In the first phase, the fission products that build up in the graphitic materials, in the coolant system, in graphitic dust, and plateout in the primary circuit during normal operation dominate the radionuclides that can be released into the reactor building. Specifically:

1. The circulating activity is transported to the reactor building during the blowdown in proportion to the amount of helium that is released.

2. A fraction of any accumulated dust on surfaces in the primary circuit can be reentrained if the local coolant depressurization velocities increase sufficiently.

3. A fraction of the material that is plated out in the reactor coolant system can liftoff during the blowdown. The liftoff fraction is a function of shear ratio, wall shear stress, blowdown duration, temperature, humidity, and surface oxidation state. In depressurization events, which also include water ingress (e.g., a major tube leak in a steam generator located in the primary loop), the effects of steam washoff will affect the rate of radionuclide reentrainment.

4. The release from the fuel, fuel matrix, and graphite depends on the time at temperature.

5. The release to the environment is affected by the removal of radionuclides in the reactor cavity and the other volumes of the reactor building and the action of the reactor building vent system.

The release to the environment in this first phase depends on the rate of depressurization. Prior analyses for the PBMR DPP (an HTGR design program in South Africa) and the prismatic modular HTGR conclude that feasible leak sizes are limited and the initial release does not dominate the source 
term for limited depressurization events. Very large breaks of negligible probability of occurrence were evaluated as part of BDBA analyses, and the initial release was found to dominate the source terms for those events. The largest release occurs during the initial blowdown, which is vented from the reactor building. Once the blowdown is complete, there is relatively little driving force from the primary circuit to the reactor building to affect significant releases during the later core heat-up phase of the event.

Core heat up is the second phase of this event. The most limiting depressurization event includes a depressurization and a loss of all active cooling flow that results in core heatup under conduction cooldown conditions to the reactor cavity cooling system, referred to as a depressurized loss of forced cooling event. Under these conditions, the source term consists of the early release containing the circulating activity, dust and liftoff during blowdown, and then a longer term release associated with the heatup of the core over about 100 hours. Depending on the size of the leak, the blowdown and the core heatup phase may overlap. In this case, the driving force for the release is the extended blowdown of the coolant system. If the blowdown phase is short relative to the heatup phase (as would be the case for a large break), the driving force for this longer release is associated with the slow heatup of residual helium in the system following blowdown and the dynamics of how the reactor cavity communicates with the other volumes in the reactor building.

During the core heat-up phase, the initially defective particles with exposed kernels and those assumed to fail in service will release fission gases and metals. Particles with a SiC defect and an intact $\mathrm{IPyC}$ and/or OPyC layer will release metals. Releases are strong functions of time at temperature, the accumulated burnup prior to initiation of the event, and whether moisture is present, which can cause hydrolysis of exposed kernels (e.g., water ingress in the event of a major steam generator tube leak). Based on the available experience with transport of fission products in the TRISO coating layers, except for tritium and silver, diffusion through intact particles is not expected if peak accident fuel temperatures remain below about $1600^{\circ} \mathrm{C}$ for less than about 200 hours. Higher fuel temperatures can exist for shorter periods of time without diffusion of fission products through the coating layers. (Fission product transport code models include the behavior of those fission products that can be released from intact particles.)

Similar to normal operation, the graphitic materials (matrix and fuel element graphite) do not retain fission gases and iodine, but experience indicates that fission metals like strontium and europium are strongly retained in these materials unless temperatures approach $1800^{\circ} \mathrm{C}$. Retention in the graphitic materials is anticipated to be a strong function of graphite temperature and also fast neutron fluence.

The fission gases, the fraction of iodine, and the small fraction of fission metals that permeate through the graphite and do not plateout on the primary circuit components are released to the reactor building. As noted, the driving force in this phase of the event is the heat up of the residual helium and, in the case of water ingress events, steam and water in the core.

There are important mass-transport limitations associated with this phase of the accident that are very design dependent as natural convection and exchange flow phenomena dominate the behavior of the gas. The distribution, settling, and condensation of radionuclides in the reactor cavity and the remainder of the reactor building, as well as the action of any reactor building filtering and leakage, establish the source term released to the environment. In the prior analyses of the PBMR DPP and the modular HTGR, this phase of the event was determined to dominate the magnitude of the source terms for all DBEs.

\subsubsection{Functional Containment}

As described above, the multiple barriers to fission product release and radionuclide transport described in this paper form a functional containment limiting the release of radionuclides to the environment. This functional containment is comprised of the kernel and coatings of the TRISO coated fuel particles, the fuel matrix and fuel element graphite, the primary circuit, and the reactor building. Each 
of these barriers contributes to limiting the release of radionuclides to the environment to meet the NGNP Project top level radiological criteria. The contribution of each of the barriers in limiting the transport and release of radionuclides to the environment is calculated for each postulated event, depending on the response of the reactor to the event. A representation of the relative contribution of each of these barriers is shown in Figure 4-2 for an example postulated depressurization event. The data used for this figure were developed as part of prior accident analyses of a prismatic HTGR. The ordinate is on a logarithmic scale in curies.

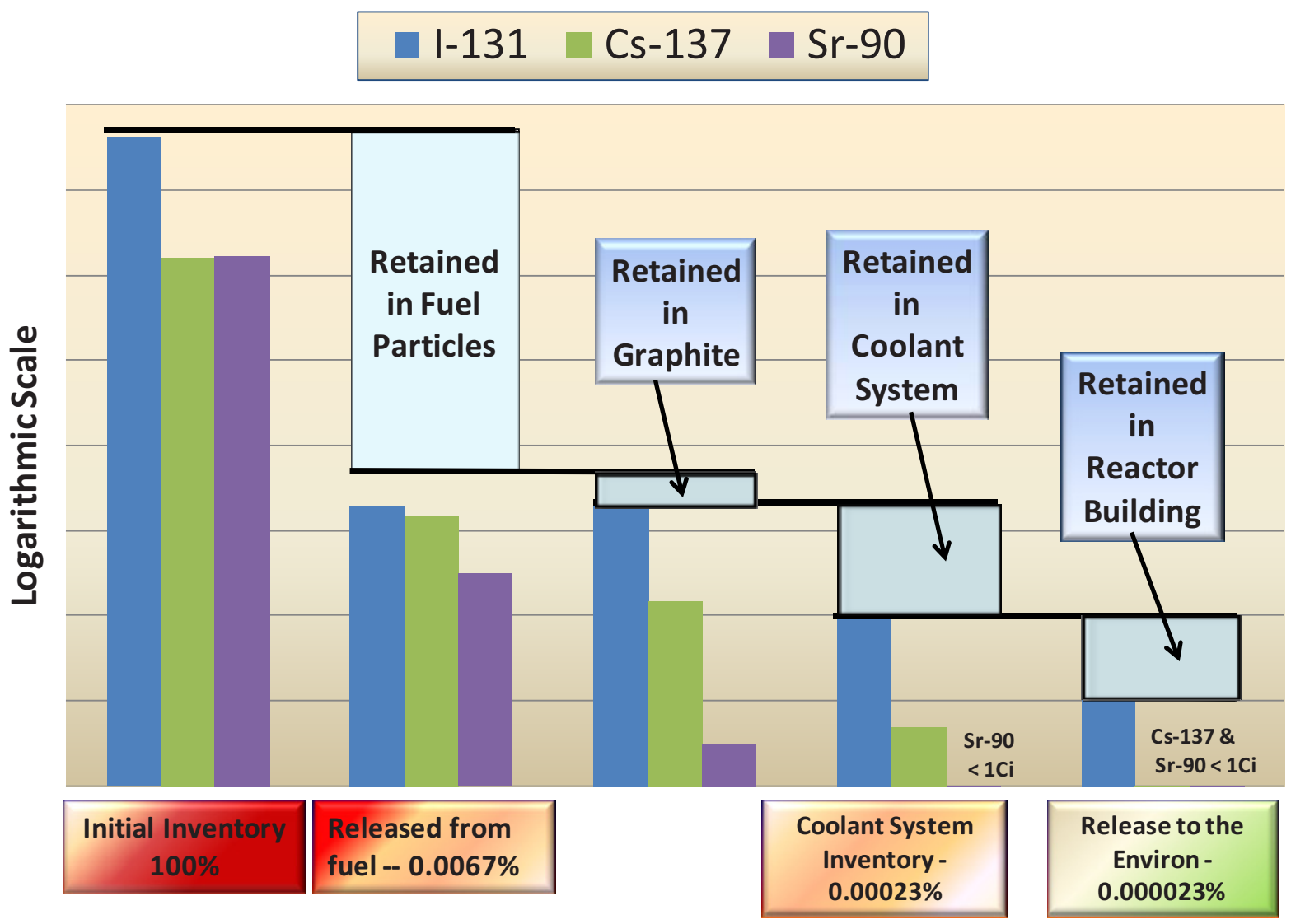

Figure 4-2. Relative contribution of each barrier to limiting radionuclide release to the environment for an example postulated depressurization event.

The fuel kernel and the fuel particle coatings are the principal barriers to fission product release. In the Figure 4-2 example, the fuel particles have retained $99.9985 \%$ of the fission products. The release fraction was calculated factoring in the effects of initial particle production quality (a certain number of new particles are assumed to have defective coatings), heavy metal contamination, incremental in-service and accident condition particle coating failure rates, and diffusion of fission products through the particle coatings under normal operating and accident conditions. These latter factors are calculated on an eventspecific basis, depending on the burnup of the fuel, maximum operating temperature, and maximum temperature reached in the accident and, where applicable, air and/or water contamination, (e.g., a steam generator tube rupture).

As shown in the example, the fuel matrix and fuel element graphite (e.g., the pebble bed spherical fuel element or the prismatic fuel compacts and fuel blocks) provide retention of metallic fission products (e.g., cesium by a factor of 10 and strontium by a factor of more than 100) but are essentially transparent to the gaseous forms (e.g., iodine). 
During normal operation, the inventories of most species of radionuclide released into the primary circuit will reach a steady-state concentration governed by radionuclide half life, the release rate from the fuel particles through the graphite to the coolant system, plate out of radionuclides on primary circuit components, performance of the helium purification system, and adsorption of radionuclides on graphitic dust and settling of the dust in areas of lower velocity. (The primary circuit inventory of long-lived condensable radionuclides such as $\mathrm{Cs}-137$ and $\mathrm{Sr}-90$ continues to increase during the lifetime of the facility.) During the initial phase of a depressurization event, this steady-state concentration is essentially the inventory of radionuclides potentially available for release to the reactor building. As the event progresses, the concentration of radionuclides in the coolant released to the reactor building will be affected by additional factors such as reentrainment of dust, liftoff of plated-out radionuclides, and washoff of radionuclides if the event includes water ingress. For the event shown, all of these factors account for a substantial reduction in the radionuclide activity that is released into the reactor building.

Finally, as the helium coolant and radionuclides pass through the reactor, steam generator, and intermediate heat exchanger cavities, the other volumes of the reactor building, and are ultimately vented to the environment, a fraction of the radionuclides are retained in these volumes through settling, condensation, and, if installed, vent filtering. As shown for this event, the reactor building retains another order of magnitude of the radionuclide activity. The activity is dominated in this example by I-131 such that the Cs-137 and Sr-90 do not show on the logarithmic scale.

Figure 4-2 is only representative of the activity level of each of the species shown. There are other radionuclides that must be considered. The levels at which each of these can be released is determined by its contribution to the calculated TEDE.

Section 5 summarizes the testing programs that are underway to develop and validate the characteristics of each of these functional containment barriers across the full range of normal and postulated accident conditions to support development of the analytic tools required to complete design and safety analyses, including the calculation of source terms.

\subsection{Fission Product Transport Codes}

Several analytical tools are used to model and calculate fission product generation, transport, and release to the environment. To a large extent, these include computer codes that are specific to the reactor designer. The purpose of this section is to provide an overview of the principal fission product transport codes used in the design and analysis of the HTGR core design types currently under consideration for the NGNP project - the prismatic fuel block and the pebble bed core. Additional detail regarding specific codes for these core designs is provided in Appendices D and E, respectively.

Generally speaking, separate sets of codes are used to calculate the distribution of fission products in the core and in the primary cooling system during normal operation (the initial conditions for accident analysis) and the behavior of the fission products during accident sequences, including any incremental, additional fuel failure and fission product transport and release.

Fuel particle failure fractions vary in space and time, the fractional releases from contamination and failed particles vary in space and time, and partially failed particles (particles with a failed $\mathrm{SiC}$ coating but with intact IPyC and/or OPyC coatings) must also be considered. Fission product transport behavior in the reactor core and around the primary cooling system varies by species and with temperature and is affected by the materials used in the core and the primary cooling system. Consequently, full-core computer codes and models of the entire primary cooling system are needed to track these effects.

The demonstrated capability to predict with sufficient accuracy full core fuel performance and fission product transport and release under both normal operating conditions and accident conditions is important to HTGR fuel qualification, mechanistic source term qualification, and determination of required design 
margins. Accordingly, all of the various major international HTGR technology development programs have included extensive efforts to model coated particle fuel performance and radionuclide transport in HTGRs (IAEA 1997 and Martin 1993).

\subsubsection{Prismatic Fuel Fission Product Transport Codes (General Atomics)}

Prediction of source terms involves the use of multiple codes to provide the requisite input into the fuel performance and fission product transport codes. The principal General Atomics design codes and interfaces for predicting fuel performance and fission product release from a prismatic core during normal operation and core conduction cooldown accidents are shown in Figure 4-3. Appendix D provides a table that summarizes these and other codes used by General Atomics to calculate radionuclide source terms for prismatic fuel HTGRs. Analogous codes for use in source term calculations for prismatic core designs are in various stages of development at AREVA.

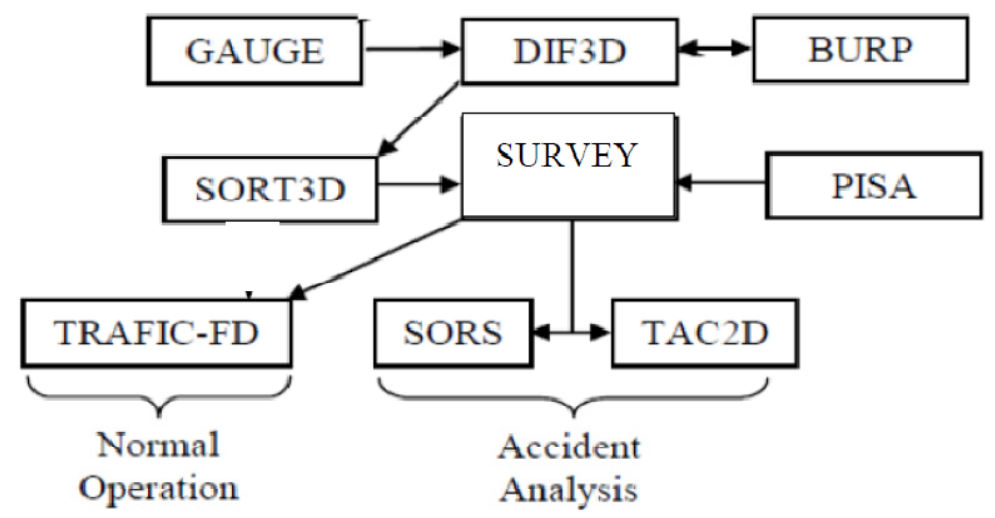

Figure 4-3. Key interfaces between prismatic HTGR core analysis codes (General Atomics).

The GAUGE, BURP, and DIF3D code packages are used to conduct the core nuclear analyses that provide time-dependent 3-D power distributions to support core thermal analyses. The thermal analyses in turn provide input for use in calculations of coated-particle fuel performance and fission product transport. The principal codes from Appendix D that were developed at General Atomics to predict fuel performance and fission product transport include PISA, CAPPER, TRAMP, SURVEY, TRAFIC-FD, PADLOC, POLO, and SORS. PISA was developed to calculate fuel coating pressure vessel failure probabilities. CAPPER and TRAMP are used to calculate fuel performance and fission product release from the fuel for irradiation test capsules, and SURVEY and TRAFIC-FD perform the same calculations for entire HTGR cores under normal operating conditions. PADLOC calculates the distribution of condensable fission products in the primary circuit under normal operating conditions. POLO calculates the reentrainment (liftoff) of the condensable fission products in the primary circuit during depressurization events and calculates the attenuation of radionuclides in the reactor building and out to the environment during and following depressurization transients. SORS is used to calculate fission product release from the fuel particles during core heat-up accident conditions. Appendix D includes brief discussions of these codes.

\subsubsection{Pebble Fuel Fission Product Transport Codes (PBMR [Pty] Ltd.)}

This section provides information on the approach to calculating fission product generation, transport, and release for pebble bed HTGRs. The methods used for these analyses are continuously evolving. Additional information can be found in (Rollig 1977; van der Merwe, J. J. and J. H. Venter 2009; van der Merwe, J. J. and I. Clifford 2008; and van der Merwe, J.J. 2009). 
Fission product release analysis for the pebble bed design is divided into relatively short-lived gaseous and long-lived metallic fission products. Fission product release analyses are summarized in Figure 4-4. The reactor design is analyzed by the core neutronics codes (Very Superior Old Programs [VSOP] for normal operation and TINTE for accident conditions) and by the thermal hydraulic code CFD. These codes supply the necessary input parameters (temperatures, neutron fluxes, power densities, residence times, etc.) for the fission product release codes NOBLEG (gases) and FIPREX/GETTER (metals) to calculate the fission product releases from the pebble bed core. NOBLEG and FIPREX/GETTER are codes used to analyze fission product transport from the fuel into the helium coolant. NOBLEG determines gaseous releases during normal operation, while FIPREX/GETTER calculates normal operation and transient diffusion behavior for metallic fission products.

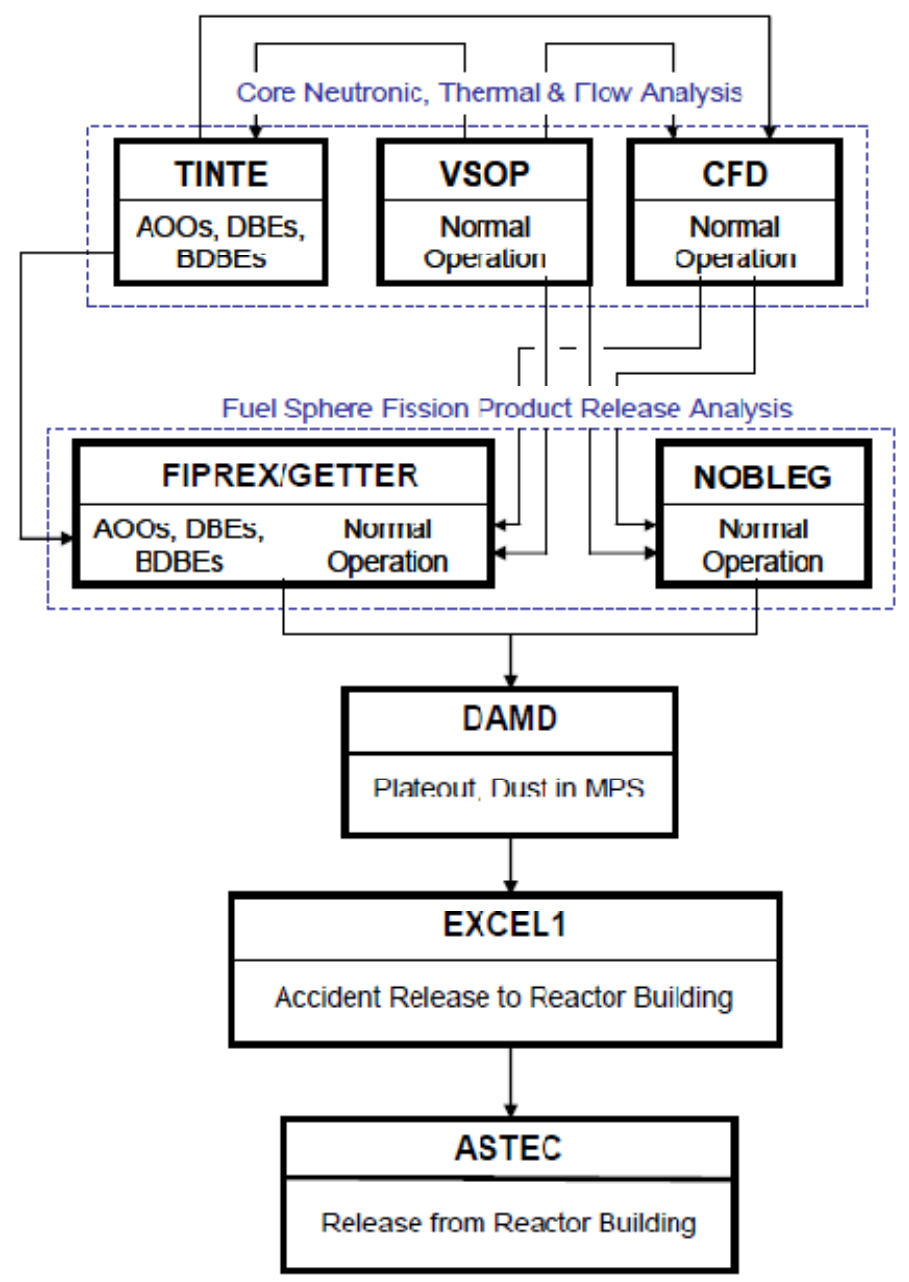

Figure 4-4. PBMR fission product release analyses.

These fission product release values are used by the dust and plateout simulation code DAMD (Dust and Activity Migration and Distribution) to calculate the fission product concentration in the main power system. These fission product concentrations are then used to determine the radiological doses that operational personnel might experience during maintenance work at the PBMR. The fission products released from the main power system into the reactor building during accidental leaking or pipe breaks are modeled by EXCEL1. The fission product behavior in the reactor building and final release into the environment are modeled by ASTEC and other software that incorporate plant reactor building design and meteorological parameters. 
Appendix E provides brief summary descriptions of these codes.

\subsection{Radionuclide Transport Data from Operating HTGRs}

The best indication of the validity of the design methods used to predict radionuclide source terms for HTGRs is the comparison of code predictions with actual surveillance data from operating HTGRs. Such comparisons have been made for both prismatic and pebble bed HTGRs, and the results have been documented in various review reports, including "Fuel Performance and Fission Product Behavior in GasCooled Reactors" (IAEA 1997). The results are illustrated in the following discussion, with emphasis on surveillance data from HTGRs with TRISO-particle fuel, since that fuel form will be used in the NGNP.

\subsubsection{Prismatic HTGR Data}

The most comprehensive data currently available for a TRISO-fueled HTGR are from surveillance measurements made at FSV. In the future, it is anticipated that significant reactor surveillance data will become available from the Japanese HTTR.

The FSV Nuclear Generating Station was an 842 MWth HTGR that was operated by the Public Service Company of Colorado from 1974 to 1989. The FSV core used prismatic fuel elements with hexagonal cross sections. The FSV fuel element was essentially identical to that specified for the commercial GT-MHR, and it was the point of departure for optimization of the fuel element for the prismatic NGNP concept. Fuel for the reactor was based on the $93 \%$ enriched uranium/thorium cycle. Separate, TRISO-coated $(\mathrm{Th}, \mathrm{U}) \mathrm{C}_{2}$ fissile and $\mathrm{ThC}_{2}$ fertile particles were used.

The standard General Atomics fuel and reactor core design codes were used to predict the fuel performance and fission product release from the FSV core during operation. As-operated core power levels, corresponding 3-D power distributions, and measured and calculated coolant flow rates and temperatures were used to calculate the fuel element temperature histories at a large number of locations in the reactor core. The reference fuel performance computer code SURVEY and the metallic fission product release code TRAFIC were used.

The SURVEY code calculated the fuel-failure distribution and the full-core fission gas release. The predicted and measured fission gas release histories for $\mathrm{Kr}-85 \mathrm{~m}$ are compared in Figure 4-5. In the figure, the measured release rates are shown as points; the calculated release rate-to-birth rate ratios $(\mathrm{R} / \mathrm{Bs})$ from as-manufactured heavy metal contamination plus release from particles whose coatings failed in service are shown as the solid line, and the R/Bs from the heavy metal contamination alone are shown as the dashed line. The dominant source of coating failure in FSV was predicted to be the fast-fluence-induced failure of OPyC coatings on particles with as-manufactured $\mathrm{SiC}$ defects, resulting in an exposed kernel. The measured $\mathrm{R} / \mathrm{Bs}$ indicate that there was less coating failure than predicted for most of the operation of FSV. The noble gas release from FSV at end-of-life was over-predicted by about $2 \times$-well within the $4 \times$ accuracy goal (Section 2.4).

Data were obtained on the metallic-fission product release from the FSV core into the primary circuit from two plateout probes. These probes were designed to sample vapor and aerosol-borne condensable fission products in the helium by drawing a small portion of the helium coolant into the probe. Plated-out metallic fission products were also measured on one of the circulators (designated C2105) located downstream from the steam generators. 


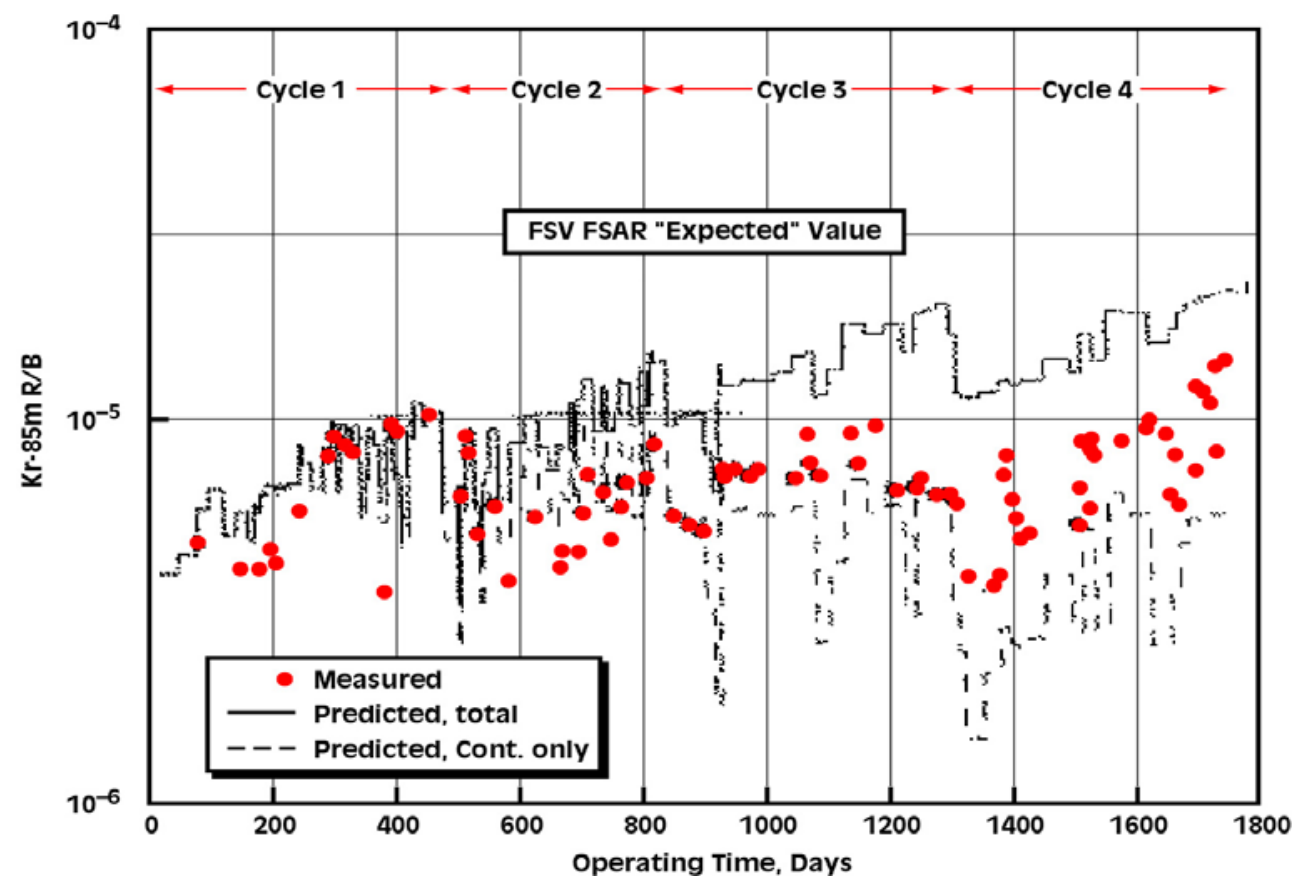

Figure 4-5. Predicted and measured $\mathrm{Kr} 85 \mathrm{~m} \mathrm{R} / \mathrm{B}$ in FSV.

The TRAFIC computer code was used to predict the release of fission product metals from the core during FSV operation. Analyses were performed for the key nuclides including Sr-90, Cs-134, and Cs-137. The calculated cumulative releases are compared with the actual total releases derived from the plateout probe data in Figure 4-6. The Sr-90 plateout based on the plateout probe data was over predicted by $1.4 \times$, primarily because of overprediction of the amount of its gaseous precursor $\mathrm{Kr}-90$ (Sr-90 plateout comes almost exclusively from this source). The Cs release was predicted to well within the design goal of $10 \times$ (Section 2.4) for predicting fission product metal release. Based on the plateout probe data and plateout data from the $\mathrm{C} 2105$ circulator, the fission product inventories were significantly lower than the "expected" values given in the FSV Final Safety Analysys Report. Since the fuel in FSV was highly enriched uranium /thorium, the total production of silver isotopes was low compared to the cesium isotopes, and the small release of Ag-110m from the core could not be reliably measured. (Silver production results primarily from the fissioning of plutonium isotopes.)

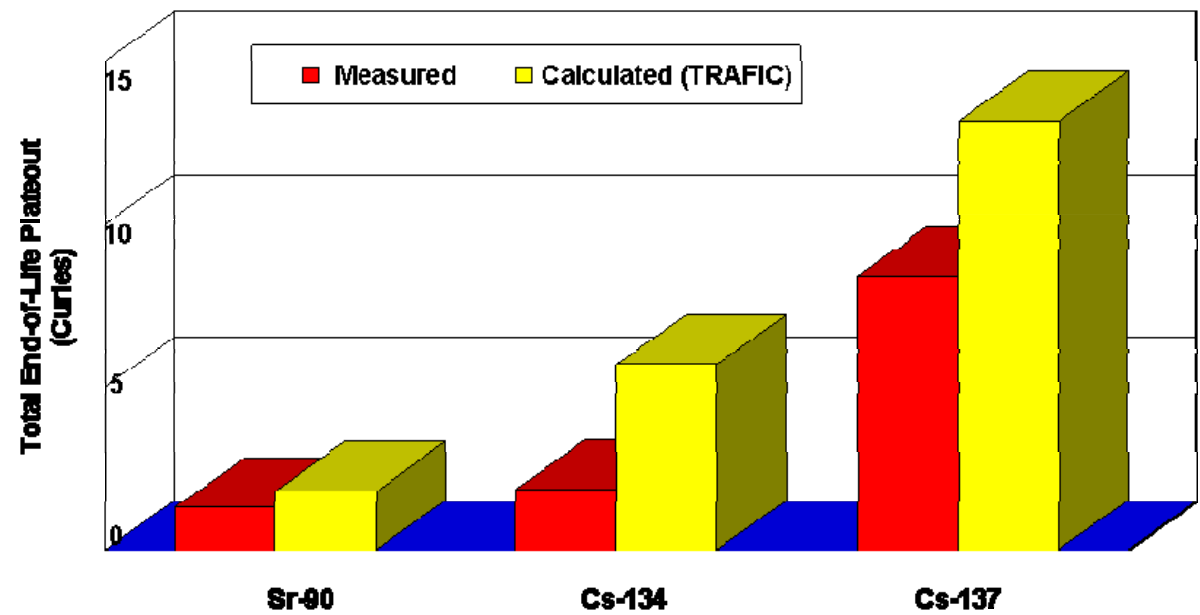

Figure 4-6. Calculated and measured fission-metal release in FSV. 


\subsubsection{Pebble Bed HTGR Data}

Reactor surveillance data from AVR has been used to validate design methods for predicting source terms. The main focus is on the DAMD software code system that models the activation, migration, and time-dependent distribution of dust and atomic particles in a HTR (Stoker 2008). The task is complicated by the large variety of coated-particle fuels that were irradiated and tested in the AVR, ranging from bistructural isotropic (BISO) fuel to high-quality LEU $\mathrm{UO}_{2}$ TRISO-reload fuel.

DAMD was developed specifically for integrated effects modeling within a typical pebble bed HTGR system. The use of the AVR data is the first nuclide transport validation effort for DAMD. The preliminary comparisons of DAMD with the AVR measurements indicate agreement between measured and calculated radionuclide concentration within a factor of 10 in the majority of locations. DAMD models, methodologies, and software will be further improved as development of the code continues. Furthermore, the ability to perform sensitivity analyses with DAMD to evaluate system responses provides the capability to define bounding cases for the PBMR design and safety evaluations. The continuous AVR operating experience validation effort for the PBMR radionuclide source term analyses also includes VSOP-computational fluid dynamics reactor simulations; fuel performance predictions taking the different fuel types into account; and radionuclide, dust transport, and activation analyses.

In addition to the analyses of AVR operating data, the results of irradiation of spherical fuel elements in test reactors have been used to validate design methods for use in determining source terms. An example of the verification and validation of the NOBLEG code for gaseous fission product release is the results of the benchmarking evaluation of irradiation test HFR-K6 (van der Merwe 2004; van der Merwe 2008). The fuel proof test HFR-K6 was originally designed to test the fuel elements for the planned HTRMODUL and was the final proof test of the German HTR fuel development. Four $60-\mathrm{mm}$ reference fuel elements from AVR-21 reload batch with LEU TRISO-coated particles (A1K6, B1K6, B2K6, C1K6) were selected and inserted into the high-flux reactor (HFR) at Petten.

The expected release from a single failed particle significantly exceeds the measured release from test elements A1K6, B1K6, and B2K6. It can therefore be deduced that no particle failure occurred in these three elements. Fission product releases for these test elements are therefore determined by the uranium and thorium contamination of the OPyC layers of the coated particles and the graphitic matrix material of the fuel element.

The $\mathrm{Kr}-88$ and $\mathrm{Xe}-135 \mathrm{~m}$ release, simulated with NOBLEG for test element B1K6, is presented in Figure 4-7 and Figure 4-8, respectively. Xe-135m was selected to represent the xenon and iodine gas release. It is also a conservative approach to determine iodine release by assuming that xenon release behavior is similar to iodine release behavior. Test element B1K6 was chosen for presentation as its irradiation history had the most consistently available and coherent measurements. The NOBLEG simulation matches the measured releases well, and the largest difference between the measured and calculated values is a factor of 2, well below the accepted PBMR design factor discussed in Section 2.4. These results support the validation of NOBLEG for the calculation of noble gas and halogen release from heavy metal contamination.

After investigating the fission gas release during irradiation, it was concluded that test element C1K6 had two failed particles that were as-manufactured defects. No particle failure occurred during irradiation. The fission gas release from this test element is thus dominated by release from the two defective particles, as the free uranium from one failed particle exceeds the free uranium in the matrix material by a factor of 35. The measured fission gas release from test element C1K6 is compared with the calculated values in Figure 4-9 for Kr-88 and Figure 4-10 for Xe-135m, respectively. Considering the measurement uncertainties, the agreement between the measured and code calculated values is very good. The values calculated are within a factor of 2 for $\mathrm{Kr}-88$ and within a factor of 3 for $\mathrm{Xe}-135 \mathrm{~m}$ of the measured values. 


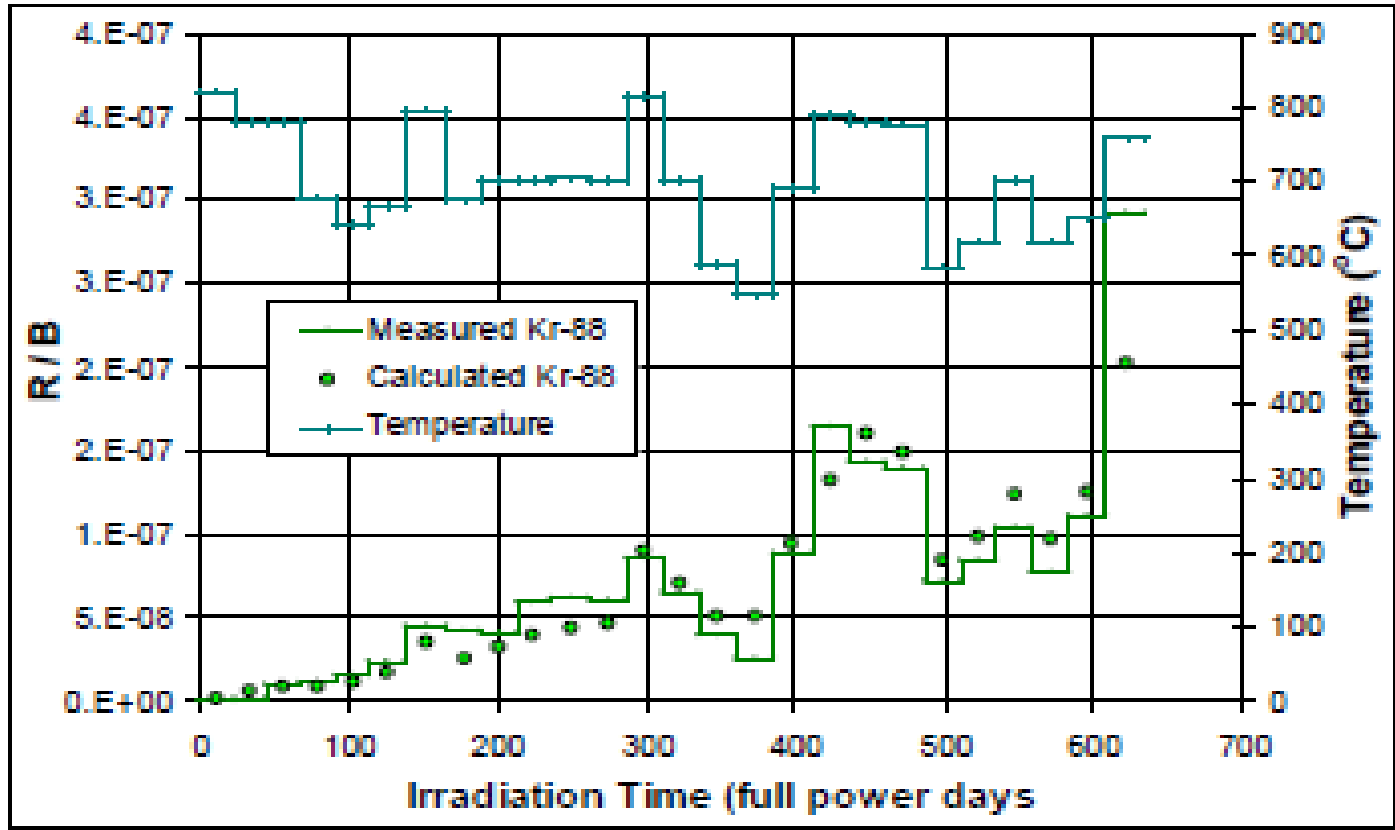

Figure 4-7. Measured and calculated $88 \mathrm{Kr} \mathrm{R} / \mathrm{B}$ comparison for test element B1K6 (contamination release).

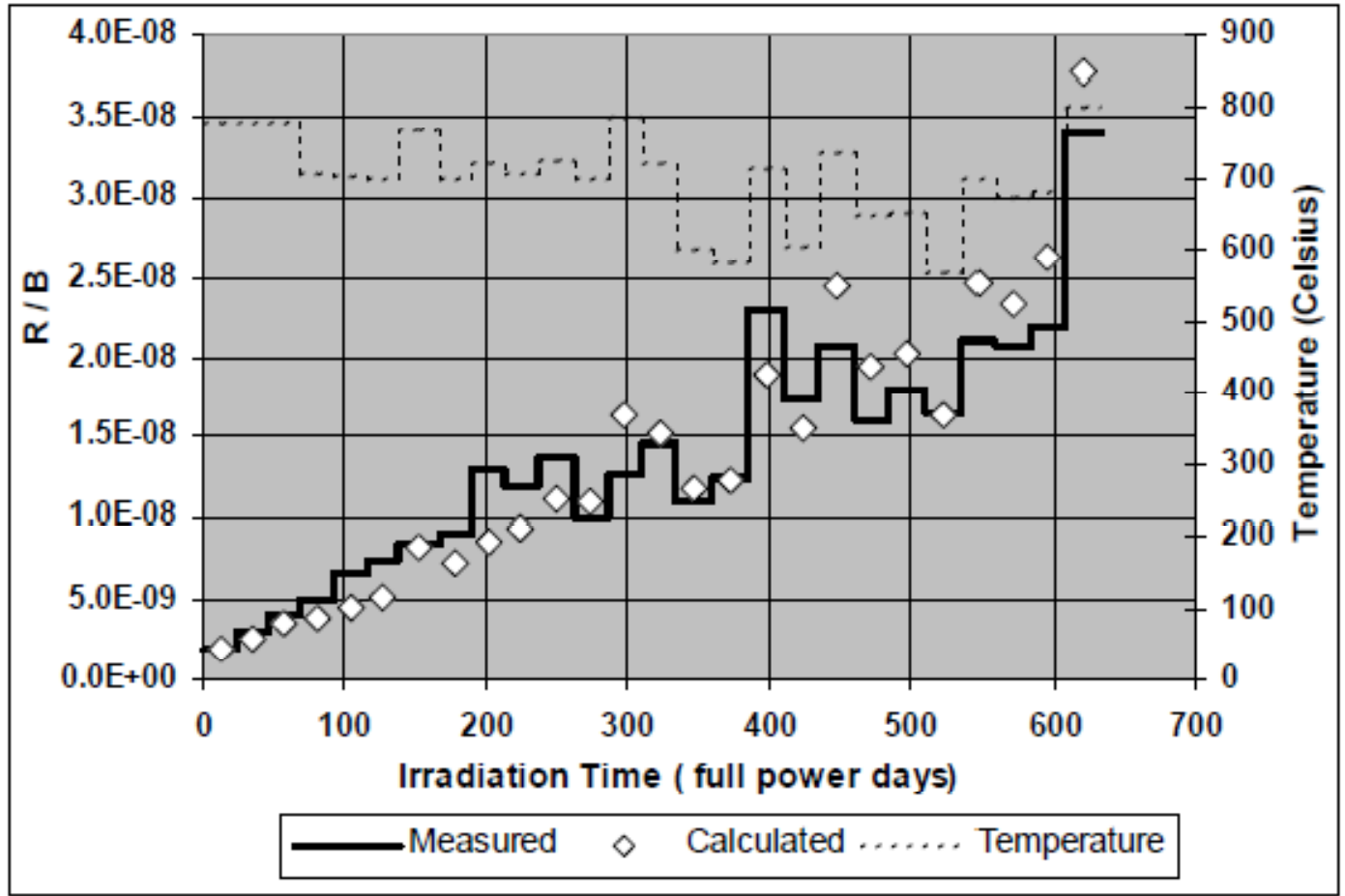

Figure 4-8. Measured and calculated $135 \mathrm{mXe} \mathrm{R} / \mathrm{B}$ comparison for element B1K6 (contamination release). 


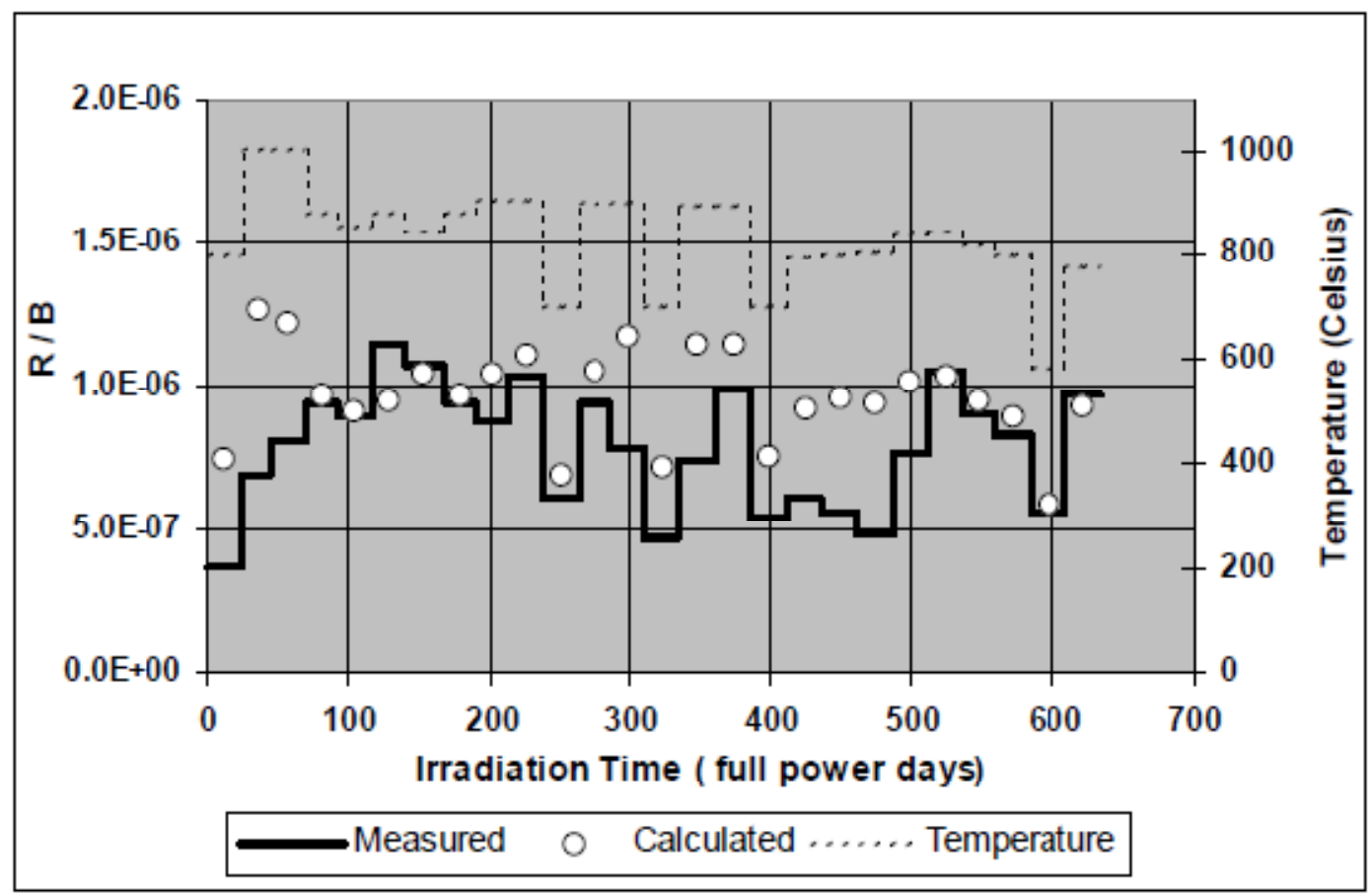

Figure 4-9. Measured and calculated 88Kr R/B comparison for test element C1K6.

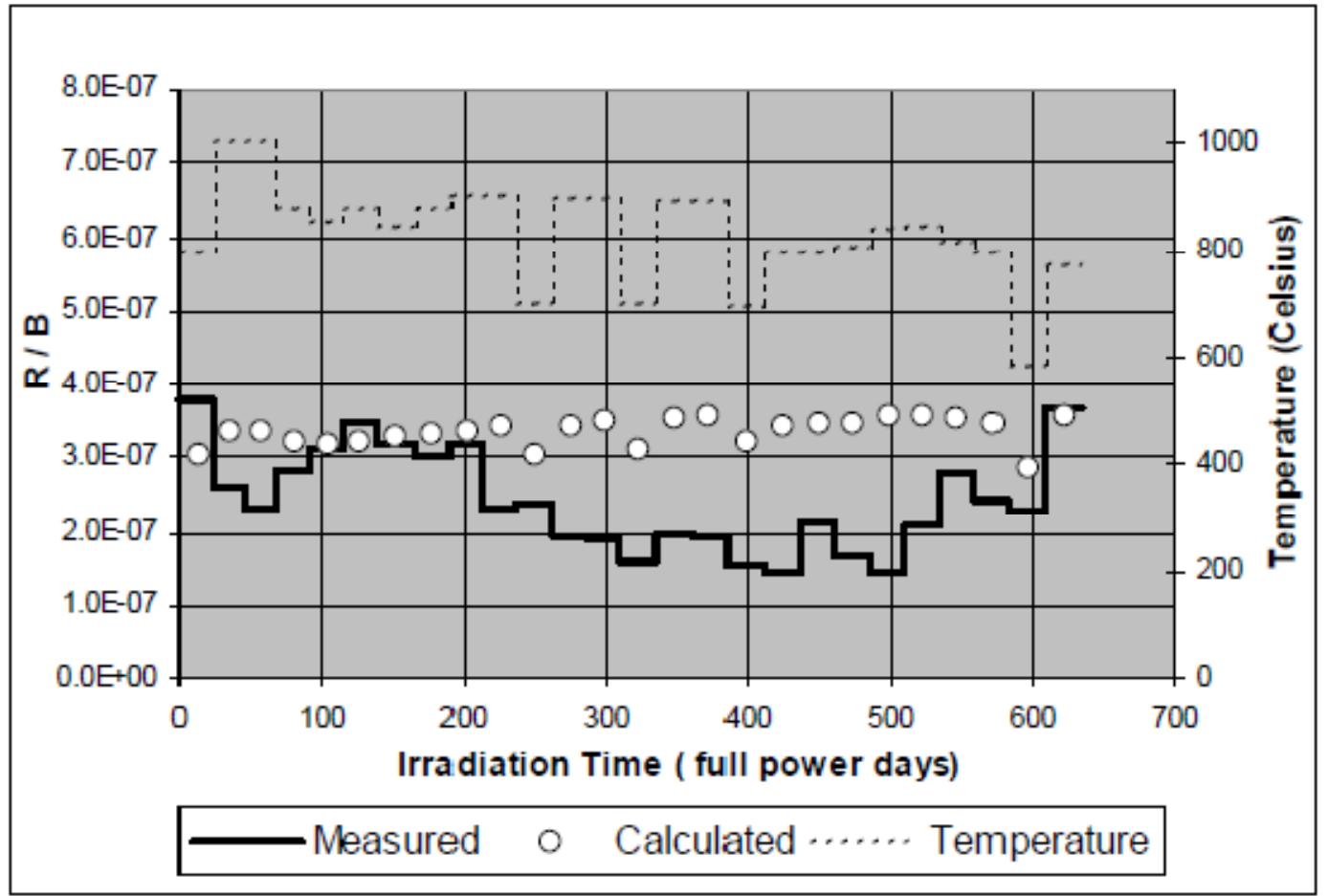

Figure 4-10. Measured and calculated 135mXe R/B comparison for test element C1K6.

This is within the PBMR design factor for noble gases and halogens discussed in Section 2.4. These results support the validation of NOBLEG for the calculation of noble gas and halogen release from failed fuel particles. 
An example of the verification and validation of the GETTER code for metallic fission product release is the results of the benchmarking evaluation of irradiation test HFR-K3 (van der Merwe 2004). HFR-K3 was part of the German HTR fuel development program, employed to test fuel systems and validate the design and production of low-enriched fuel spheres. After considering all the available experimental results and irradiation conditions, the test elements $\mathrm{A} 5 \mathrm{~K} 3$ and $\mathrm{B} 6 \mathrm{~K} 3$ were chosen for validation of the fission product release code GETTER.

Test elements $\mathrm{A} 5 \mathrm{~K} 3$ and $\mathrm{B} 6 \mathrm{~K} 3$ underwent post-irradiation heat-up tests. Test element $\mathrm{A} 5 \mathrm{~K} 3$ was heated for 500 hours at $1600^{\circ} \mathrm{C}$ and test element B6K3 for 100 hours at $1800^{\circ} \mathrm{C}$. Fractional releases of the major fission products were measured during the heat-up tests. The fuel free zone was investigated and the fission product content measured as well as the total fuel element fission product inventory. The R/B values for released fission gases during irradiation were below $1 \times 10^{-6}$ for all capsules, so that the possibility of failed particles could be neglected. The GETTER calculation was therefore done with the assumption that no failed particles were present. The final fractional release values for the two test elements were measured together with detailed analysis of the sphere component activity contents. The comparison between the measured values and the GETTER calculated results for Cs-137 and Ag-110m show a conservative estimate of the expected release. The Cs-137 calculated release is a factor 2.7 higher than the measured release, which is well below the uncertainties accepted for PBMR design analyses discussed in Section 2.4. The Ag-110m calculated release is a factor of 30, too high, versus the uncertainty factor of 20 for silver release accepted for PBMR design analyses (Section 2.4). This suggests that the current transport parameters used in this analysis were too high and need to be refined based on further study. The calculation is, however, still conservative. The fission product concentration profiles in the fuel-free zone measured during the post-irradiation examination (PIE) were compared with the GETTER calculated values. The Cs-137 fuel-free zone concentration is overestimated by a factor of 4 for Cs-137 and for Ag-110m by a factor of 3.5 by GETTER. This is within the design factor commonly accepted for comparisons of calculations and measurements discussed in Section 2.4. Furthermore, it proves GETTER's conservative estimation of experimental and operational conditions. 


\section{TECHNOLOGY DEVELOPMENT REQUIRED FOR SOURCE TERM VALIDATION}

Although the methodology proposed herein for deriving mechanistic radionuclide source terms for the HTGR is considered reasonable and credible based on the available knowledge base, additional technology development will be needed to generate the necessary data to formally validate these source terms. The ongoing NGNP/AGR Fuel Program (INL 2008) is intended to provide the data needed to supplement the existing international knowledge base. When the program is completed, the augmented knowledge base should be sufficient to address the NRC staff's recommendations in various SECY documents, as discussed in Section 0, for qualifying a mechanistic source term.

Table 5-1 presents a high-level summary of the mechanistic source term knowledge gaps that need to be addressed based on the discussions in Section 4 and Appendix C. Plans to address these gaps are presented in this section. One indication of the required technology development is available from the NRC Phenomena Identification and Ranking Table (PIRTs), which reflect regulators' current perspective regarding knowledge gaps.

Table 5-1. Summary of major mechanistic source-term knowledge gaps.

\begin{tabular}{|c|c|}
\hline Gap Title & Gap Description \\
\hline $\begin{array}{l}\text { Fission product } \\
\text { release from } \\
\text { intact and failed } \\
\text { particles under } \\
\text { accident } \\
\text { conditions }\end{array}$ & $\begin{array}{l}\text { The database for fission product release from intact and failed particles under accident conditions draws on } \\
\text { information from a range of carbide, oxide, and oxycarbide fuels that do not systematically encompass the } \\
\text { types of fuel and the service envelope of the NGNP Project. Accordingly, the release behavior needs to be } \\
\text { confirmed by experimental data for the pebble bed and prismatic block reactor fuels at the temperatures, } \\
\text { burnups, and fast fluences anticipated for the NGNP Project. Additional data are needed to characterize } \\
\text { water ingress effects on fission product release. }\end{array}$ \\
\hline $\begin{array}{l}\text { Fission product } \\
\text { transport and } \\
\text { sorptivity in core } \\
\text { materials }\end{array}$ & $\begin{array}{l}\text { Fission product transport in core materials (fuel matrix and graphite) is a complex phenomenon that } \\
\text { depends on fission product species, temperature, material type, and irradiation condition of the material. A } \\
\text { number of different transport mechanisms appear to be taking place. Data on fission product transport in } \\
\text { these materials are based on laboratory measurements on unirradiated materials and simplified } \\
\text { measurements on irradiated materials. The suitability of using an "effective" diffusion coefficient in a model } \\
\text { based on Fick's Law of diffusion needs to be demonstrated to ensure accurate calculations of fission } \\
\text { product release to the primary circuit for use in shielding analyses and source term calculations. Also, } \\
\text { sorptivity of condensable fission products on graphite is anticipated to be a strong function of graphite } \\
\text { temperature and also fast neutron fluence, but the uncertainty under accident conditions is very large } \\
\text { because of the annealing effects in the graphite that change the sorptivity of the material. Data are needed } \\
\text { to reduce the uncertainty in this parameter }\end{array}$ \\
\hline $\begin{array}{l}\text { Fission product } \\
\text { plateout, liftoff, } \\
\text { and wash-off } \\
\text { behavior }\end{array}$ & $\begin{array}{l}\text { Laboratory data on plateout, liftoff, and wash-off of condensable fission products in the primary circuit have } \\
\text { generally been collected at partial pressures that are several orders of magnitude higher than those } \\
\text { expected to prevail in the reactor during operation. Extrapolation of the data to operating conditions entails } \\
\text { significant uncertainty. Furthermore, many of the data have been collected for materials that are not } \\
\text { representative of those used in the primary circuit. Data on wash-off by steam or water are particularly } \\
\text { limited. Additional data obtained under more representative conditions and with representative materials } \\
\text { are needed if full credit is to be taken for retention of fission products in the primary circuit. }\end{array}$ \\
\hline $\begin{array}{l}\text { Radionuclide } \\
\text { behavior in the } \\
\text { reactor building }\end{array}$ & $\begin{array}{l}\text { Models of fission product behavior in the reactor building have not been developed in detail. A review of } \\
\text { data for the behavior of fission products in LWR containments has indicated that these data are generally } \\
\text { not applicable to the HTGR. Models for the behavior of radionuclides in the reactor building require } \\
\text { extensive input, including transient radionuclide release rates into the building, physical and chemical forms } \\
\text { of these radionuclides, environmental conditions within the reactor building (temperatures, relative humidity, } \\
\text { etc.), and correlations (e.g., sorption isotherms, etc.) describing the interactions of the various radionuclides } \\
\text { with the exposed surfaces within the reactor building (e.g., metals, painted surfaces, concrete, etc.). A } \\
\text { suitable model of these phenomena and supporting data need to be developed and validated if full credit is } \\
\text { to be taken for fission product retention in the reactor building. Sandia National Laboratory is looking at } \\
\text { adapting MELCOR for this purpose. }\end{array}$ \\
\hline
\end{tabular}


Table 5-1. (continued).

\begin{tabular}{|l|l|}
\hline \multicolumn{1}{|c|}{ Gap Title } & \multicolumn{1}{c|}{ Gap Description } \\
\hline $\begin{array}{l}\text { Radionuclide } \\
\text { behavior in the } \\
\text { presence of dust }\end{array}$ & $\begin{array}{l}\text { The presence of dust in the primary cooling circuit in the form of graphitic material from abrasion or erosion } \\
\text { of graphite components or other forms of material introduced from facility construction or during facility } \\
\text { operation can, in sufficient amounts, affect the behavior of condensable fission products in the primary } \\
\text { circuit and, if released during a depressurization event, in the reactor building. The quantities and form of } \\
\text { dust in current designs for HTGRs are unknown. Data from operation of the HTTR in Japan and the HTR- } \\
10 \text { in China are expected to be most relevant to current designs. These data are needed to determine } \\
\text { whether the amount of dust in current HTGR designs is sufficient to significantly affect the behavior of } \\
\text { condensable fission products in the primary circuit and reactor building. }\end{array}$ \\
\hline
\end{tabular}

\subsection{NRC PIRTs}

The PIRT process is an NRC protocol for providing an expert assessment of safety-relevant HTGR phenomena and for assessing NRC's research and development needs-NRC's perception of the necessary safety-related technology development activities for the NGNP project. There are six NRC NGNP PIRTs at this writing. Five are documented as Volumes 2 through 6 of NUREG/CR-6944 (Ball and Fisher 2008), which is an umbrella document with Volume 1 providing an introduction to the PIRT process and summaries of the five individual PIRTs. The topics addressed by these PIRTs are thermal/accidents, fission product transport, high temperature materials, graphite, and hydrogen and process heat. An earlier TRISO fuel PIRT (NUREG/CR-6844, Vols. 1 to 3) is included in NUREG/CR-6944 (Morris 2004). Only the TRISO and fission product transport PIRTs are directly relevant to mechanistic source terms, although the other PIRTs do, in principle, contribute to the definition of accident scenarios, including the establishment of bounding service conditions for the fuel.

A study was made at Oak Ridge National Laboratory (ORNL) as a follow-on effort to the PIRT process to identify the significant "gaps" between what is needed and what is already available to NRC to adequately assess NGNP safety characteristics (Ball et al. 2008). A conclusion of this study was that through a concerted effort, the required data can be obtained and the necessary models confirmed or developed, leading to a fission product transport code for the NGNP.

Section 5.2 provides more information on the planned technology development programs for validation of mechanistic source terms.

\subsection{NGNPIAGR Fuel Program Plan for Source Term Validation}

The most important barrier to radionuclide release is the TRISO coating system on the fuel particles. Demonstrating that the NGNP fuel can meet the necessary performance and quality requirements, such as those illustrated in Table 4-3, is therefore the most important technology development requirement. The NGNP/AGR Fuel Program (INL 2008) is developing and qualifying conventional SiC-based TRISO fuel particles for use in the NGNP. Validation of the design methods for determining radionuclide source terms is also within the scope of the NGNP/AGR Fuel Program.

The two major work scopes within the NGNP/AGR Fuel Program (fuel development and qualification program and fission product transport program) are described in Sections 5.2.1 and 5.2.2. The fuel development and qualification program is also addressed in more detail in the fuel qualification white paper (INL 2010).

Both elements of the NGNP/AGR Fuel Program feature in-pile irradiation tests in the Advanced Test Reactor at INL and extensive PIE and post-irradiation heating tests in the INL Hot Fuels Examination Facility and the ORNL Core Conduction Cooldown Test Facility with test articles recovered from the irradiation tests. The overall planned irradiation program is summarized in Table 5-2. The full range of fission product transport tests are listed in NGNP/AGR Fuel Program Plan (INL 2008). 
Table 5-2. NGNP/AGR irradiation test program.

\begin{tabular}{|c|c|c|}
\hline Capsule & Test Description & Test Objective/Expected Results \\
\hline AGR-1 & $\begin{array}{l}\text { Shakedown Test/Early Fuel. Contents included compacts } \\
\text { made from UCO fuel particles coated in 2-in. laboratory- } \\
\text { scale coater at ORNL. A baseline fuel particle composite } \\
\text { and three variant fuel particle composites were tested. } \\
\text { The variants included two particle composites coated } \\
\text { using different IPyC coating conditions and one particle } \\
\text { composite coated using different SiC coating conditions. }\end{array}$ & $\begin{array}{l}\text { Gain experience with multicell capsule design, } \\
\text { fabrication, and operation to reduce chances of capsule } \\
\text { or cell failures in subsequent capsules. Obtain early data } \\
\text { on irradiated fuel performance and support development } \\
\text { of a fundamental understanding of the relationship } \\
\text { between fuel fabrication process and fuel product } \\
\text { properties and irradiation performance. Provide irradiated } \\
\text { UCO fuel for accident simulation testing (heating tests). }\end{array}$ \\
\hline AGR-2 & $\begin{array}{l}\text { Performance Test Fuel. Contents to include compacts } \\
\text { containing both } U C O \text { and } \mathrm{UO}_{2} \text { fuels. The } \mathrm{UO}_{2} \text { fuels are } \\
\text { from the U.S., PBMR and France. } \mathrm{UO}_{2} \text { TRISO to be } \\
\text { irradiated at } 1150^{\circ} \mathrm{C} \text { peak time average temperature. Two } \\
\text { UCO capsules to be irradiated at } 1250^{\circ} \mathrm{C} \text { peak time } \\
\text { average temperature. One } \mathrm{UCO} \text { capsule to be irradiated } \\
\text { at } 1400^{\circ} \mathrm{C} \text { peak time average temperature which is an } \\
\text { early margin test. }\end{array}$ & $\begin{array}{l}\text { Provide irradiated fuel performance data and irradiated } \\
\text { fuel samples for safety testing and PIE for key fuel } \\
\text { product/process variants to broaden options and } \\
\text { increase prospects for meeting fuel performance } \\
\text { requirements and to support development of final fuel } \\
\text { specification for AGR } 5 \text { and } 6 \text {. }\end{array}$ \\
\hline AGR-3/4* & $\begin{array}{l}\text { Fission Product Transport. Contents to include compacts } \\
\text { of LEU UCO particles seeded with designed-to-fail (DTF) } \\
\text { fuel LEU UCO particles to provide a well-defined fission } \\
\text { product source. Fuel test element will use a concentric } \\
\text { ring design to provide a 1-D geometry to facilitate } \\
\text { derivation of effective diffusivities. Test capsules may } \\
\text { contain other test articles as piggy-back samples and will } \\
\text { operate at different temperatures. Operation will be } \\
\text { maintained isothermal to the extent practical. }\end{array}$ & $\begin{array}{l}\text { Provide irradiated fuel performance data and irradiated } \\
\text { fuel samples for safety testing and PIE. Data on fission- } \\
\text { gas release from failed particles, fission metal diffusion in } \\
\text { kernels, and fission product retentiveness of graphite } \\
\text { matrix under normal and accident conditions for use in } \\
\text { development of fission product transport models. }\end{array}$ \\
\hline $\begin{array}{l}\text { AGR-5 \& } \\
\text { AGR-6 }\end{array}$ & $\begin{array}{l}\text { Fuel Qualification. Contents to include a single fuel type } \\
\text { made using process conditions and product parameters } \\
\text { considered to provide best prospects for successful } \\
\text { performance based on process development results and } \\
\text { available data from AGR-1 and AGR-2, variations in cell } \\
\text { irradiation temperatures. }\end{array}$ & $\begin{array}{l}\text { Provide irradiated fuel performance data and irradiated } \\
\text { fuel samples for safety testing and PIE in sufficient } \\
\text { quantity to demonstrate compliance with statistical } \\
\text { performance requirements under normal operation and } \\
\text { accident conditions. }\end{array}$ \\
\hline AGR-7 & $\begin{array}{l}\text { Fuel Performance Model Validation. Contents to include } \\
\text { same fuel type as used in AGR- } 5 \text {. The irradiation will test } \\
\text { fuel beyond its operating envelope so that some } \\
\text { measurable level of fuel failure would occur (margin test). }\end{array}$ & $\begin{array}{l}\text { Provide irradiation fuel performance data and irradiated } \\
\text { fuel samples for safety testing and PIE in sufficient } \\
\text { quantity to validate fuel performance codes and models } \\
\text { and to demonstrate capability of fuel to withstand } \\
\text { conditions beyond AGR- } 5 \text { and AGR-6 in support of plant } \\
\text { design and licensing. }\end{array}$ \\
\hline AGR-8 & $\begin{array}{l}\text { Fission Product Transport Model Validation. Contents to } \\
\text { include compacts seeded with LEU DTF UCO particles. } \\
\text { Test geometry has not yet been finalized but will likely } \\
\text { use a multifuel stack design. Capsules will operate at } \\
\text { different temperatures, and the test operating history may } \\
\text { include temperature cycling. }\end{array}$ & $\begin{array}{l}\text { Provide irradiated fuel performance data and irradiated } \\
\text { fuel samples for safety testing and PIE to determine } \\
\text { material properties and fission product gas and metal } \\
\text { releases from compacts with known quantities of failed } \\
\text { particles for use in validation of fuel performance } \\
\text { modeling and fission product transport codes. }\end{array}$ \\
\hline & Laboratory experiments and out-of-pile loop. & $\begin{array}{l}\text { Develop separate effects database on fission product } \\
\text { retention behavior in primary circuit. }\end{array}$ \\
\hline & Integral loop demonstration. & $\begin{array}{l}\text { Provide integral irradiation and accident behavior data } \\
\text { set on fission product transport in simulated primary } \\
\text { circuit for validation of fission product transport models. }\end{array}$ \\
\hline
\end{tabular}


Although there are many similarities between the two types of tests, the fuel-performance tests and the fission product transport tests have different test objectives and, therefore, will utilize somewhat different test train designs. The most significant difference is that the fission product transport tests include a known fraction of designed-to-fail (DTF) particles (with intentionally missing buffer coatings and with a thin $\mathrm{PyC}$ seal coat) that will fail early in the irradiation to provide a well-defined fission product source.

The irradiation tests listed in this table were defined early in the AGR program (ca. 2003) assuming that NGNP would be a process heat very high temperature reactor (VHTR), which would not include a steam generator in the primary circuit. Consequently, it was anticipated that large water ingress events would be extremely unlikely, and a low priority was assigned to further characterizing the effect of water ingress on fuel performance and fission product transport. The NGNP Project has recently focused on process steam applications, and supplier teams have recommended that the steam generator be located in the primary circuit based on economic considerations. Under these circumstances, large water ingress events can be anticipated to be an important risk, based on safety assessments done for earlier steam cycle HTGR designs, including the 350 MWth MHTGR (Stone \& Webster 1992). The NGNP/AGR Program recognizes that additional tests to characterize the effects of water ingress on fuel performance and fission product transport will need to be added to the program. ${ }^{\text {h }}$

\subsubsection{Fuel Development and Qualification Program}

The activities under the NGNP/AGR Fuel Program include fuel manufacturing process and quality control methods development, irradiation testing and PIE, accident simulation heating tests, and fuel model development and validation.

The overall goals of the NGNP/AGR Fuel Program, as stated in the currently released version of the technical program plan (INL 2008), are to:

- Provide a baseline fuel qualification data set in support of the licensing and operation of the Generation-IV VHTR, also selected by DOE as the reactor type for the NGNP

- Support near-term deployment of a VHTR for commercial energy production in the United States by reducing market-entry risks posed by technical uncertainties associated with fuel production and qualification

- Utilize international collaboration to extend the value of DOE resources.

A revision of "Technical Program Plan for the Next Generation Nuclear Plant/Advanced Gas Reactor Fuel Development and Qualification Program" (INL 2008), scheduled for completion in 2010, will, as deemed appropriate, update these goals to reflect recent decisions to design the NGNP for a lower reactor outlet temperature than that associated with the VHTR.

A series of irradiation tests are planned for the NGNP/AGR Fuel Program to initially demonstrate and then qualify fuel for the NGNP and follow-on plants. These are summarized in Table 5-2 above. The goals of these tests are to provide irradiation performance data to support fuel process development, to qualify fuel for normal operating conditions, to support development and validation of fuel performance codes, and to provide irradiated fuel and materials for PIE and safety testing. A detailed description of this fuel program is provided in "Technical Program Plan for the Next Generation Nuclear Plant/Advanced Gas Reactor Fuel Development and Qualification Program" (INL 2008) and "Fuel Qualification White Paper" (INL 2010).

h. Future white papers on LBEs, including air and water ingress, are planned. 


\subsubsection{Fission Product Transport Characterization Program}

Each of the barriers to radionuclide transport will be characterized by the planned test programs. As shown in Table 5-2, the NGNP/AGR Fuel Program's series of eight irradiations and follow-on accident safety tests, including separate effects and integral out-of-pile tests, are designed to qualify both the fuel, as described above, and the design methods for determining radionuclide source terms for the HTGR. Each of the AGR irradiations and follow-on safety testing are targeted to meet specific objectives as shown in Table 5-1.

The goal of the fission product transport and source term activity in the AGR program is to produce a technical basis for source terms under normal operation and accident conditions for the HTGR. The technical basis will be codified in design methods (computer models) validated by experimental data. As stated previously, the approach in the source term calculations is to take credit for all fission product transport barriers (kernels, coatings, graphite, helium pressure boundary, and reactor building) with the objective of meeting PAGs at the EAB. If the fuel particle coatings were relied on exclusively for radionuclide retention, the allowable failure fractions would need to be reduced to on the order of $4 \times 10^{-7}$ for normal operation and $2 \times 10^{-6}$ for core heat-up accidents. Such stringent limits on particle failure are challenging, at least for the foreseeable future, given that the best the highly successful German fuel development program could claim was $1 \times 10^{-5}$ at $50 \%$ confidence and $5 \times 10^{-5}$ at $95 \%$ confidence for normal operation of $\mathrm{LEU} \mathrm{UO}_{2}$ at $10 \%$ FIMA. (No particle failures were observed during the German irradiations, but these results were driven by statistical limitations imposed by the quantity of fuel tested.)

The testing and analysis activities planned in the AGR program are designed to produce validated fission product transport models accurate to within a factor of 4 for fission gas and a factor of 10 for fission metals (see Section 2.4). The $4 \times$ and $10 \times$ values have been used previously to guide the development of fission product behavior models that supported HTGR designs in the 1980s and 1990s. The experimental work in the AGR program plan is structured to provide the technical basis for validating the design methods used to demonstrate that the reactor design meets the top-level radionuclide control requirements, including limits on occupational exposure and offsite doses, at the required confidence level. This will ensure that the $4 \times$ and $10 \times$ factors are appropriate for current HTGR designs.

The fission product transport portion of the AGR program has four major components:

1. Perform irradiation and accident testing with test articles containing a fraction of DTF fuel to characterize fission product release and transport from TRISO-coated particles under normal and offnormal HTGR conditions (AGR 3/4 and associated accident safety testing)

2. Perform single effects tests in an out-of-pile helium loop to characterize fission product deposition on and reentrainment from primary system surfaces under normal and off-normal HTGR conditions (plateout and liftoff).

3. Improve and benchmark existing legacy fission product transport models using data obtained above.

4. Validate the existing legacy models and codes by performing both an integral irradiation and associated accident safety testing (AGR-8) and, if determined to be necessary, integral in-pile loop experiments.

The specific fission product transport tests within the AGR Fuel Program are summarized in the following sections.

\section{Fission Product Transport (AGR-3/4)}

In these irradiations and follow-on accident heating tests, a series of fuel compacts will contain reference TRISO-coated particles and a small fraction of DTF fuel particles. These DTF particles will consist of reference kernels with 10 - to $15-\mu \mathrm{m}$-thick pyrocarbon seal coatings. These coatings will fail 
early in the irradiation and provide a known source of fission products. They have been used successfully in past HTGR irradiations.

The irradiation will contain a number of capsules (10-12 depending on details of the design) that will span - and in some cases exceed - the burnup-temperature envelope for the NGNP Project. In addition to the fuel compact, there will be concentric rings of graphite matrix and fuel element graphite so that fission products released from the DTF fuel will be retained in these components. Loose unaltered fuel particles and DTF particles may be irradiated in separate sealed tubes (piggy-back samples) to provide specific information on fission product transport in each layer. These irradiations and the associated PIE and accident safety testing will provide data on fission product release from failed particles and diffusion in kernels, coatings, matrix and graphite. These data will be used to improve existing fission product transport models.

\section{Fission Product Transport (AGR-8)}

This irradiation and the follow-on PIE and accident safety testing constitute an integrated set of experiments to validate fission product transport models/codes under normal and accident conditions using an approximation of the fuel geometry. This multicapsule test train will include compacts seeded with DTF UCO fuel particles and will operate with different temperatures among capsules; also, it may include temperature cycling. The temperature, burnup and fast fluence conditions will bracket those required by the NGNP Project.

\section{Fission Product Transport Behavior in the Primary Circuit}

Condensable radionuclides, including iodine and volatile fission metals, released from the core during normal operation and during certain accidents, will tend to deposit on structural surfaces within the primary circuit, thereby attenuating their release to the environment. However, this plateout activity and the attendant radiation fields significantly complicate plant operations and maintenance, especially for a direct cycle plant. Correlations currently available that describe the deposition behavior of condensable radionuclides on structural metals have very large uncertainties $(» 10 \times)$. A major cause of these large uncertainties is that the sorption isotherms were typically measured in the laboratory at partial pressures orders of magnitude higher than those that occur in the reactor, and in some cases were measured on materials that are not anticipated to be used in the HTGR design.

Radionuclides that deposit in the primary circuit during normal operation may be partially reentrained and released (liftoff) from the circuit during rapid depressurization events. The correlations for predicting radionuclide reentrainment during dry depressurization transients contain very large uncertainties (»10×). The historic database has extensive scatter and lacks reproducibility.

Thus, data are needed to characterize the deposition of cesium, silver, iodine, and tellurium on structural metals. Correlations are needed that give the sorptivities of these nuclides as a function of temperature, partial pressure, surface state, and coolant chemistry for normal operating and accident conditions. In addition, data and correlations are needed for liftoff of iodine, strontium, cesium, tellurium, and silver as a function of shear ratio, wall shear stress, blowdown duration, temperature, humidity, and surface oxidation state. Laboratory-scale experiments and an out-of-pile loop are planned to improve models in this area.

An additional concern is dust. Relatively large quantities of dust are predicted to form over the life of a pebble bed reactor. Measurements in the AVR suggest this dust is submicron to micron in size. This dust could provide additional surface area for fission product deposition and compete with the primary circuit surfaces as deposition sites. Calculations are underway to determine the impact of dust on the behavior of fission products in the system. If shown to be a major impact on the transport behavior, dust must be considered in the fission product transport testing plans. 
Independent integral validation test data are needed for plateout and liftoff of key radionuclides from deposits on primary circuit metals during normal operation and rapid depressurization transients, including the effects of dust, to validate the behavior of key fission products in the primary system. The presence of circulating and/or deposited particulate matter in the primary circuit will alter the plateout distribution in the circuit during normal operation and the extent to which condensable radionuclides are released from the circuit during depressurization transients. Several technical options are being considered for this work.

The extent of additional testing needed to validate the models used to establish plateout and liftoff rates of condensable fission products (e.g., the need to conduct additional in-pile and out-of-pile fission product transport tests or other less complex tests to validate plateout and liftoff models and codes) is an open issue still under discussion by the NGNP Project staff. In addition to other issues, the selection of LBEs, degree of conservatism in analysis methods required for the various types of LBEs, allocation of uncertainty in the effectiveness of each of the five barriers to fission product transport, and extent to which each barrier is counted upon to mitigate fission product transport and release must be taken into account. Resolution of this open issue is expected to occur as the plant design process progresses and as agreement is reached regarding the scope of LBEs for the NGNP.

\section{Fission Product Transport in the Reactor Building}

Data are needed to develop and validate the methods describing the transport behavior of condensable radionuclides in the reactor building under wet and dry conditions. No direct measurements have been taken of radionuclide removal from contaminated helium by condensation, settling, and plateout under conditions expected in the reactor building during a depressurization transient. The extensive LWR database on the behavior of radionuclides in steam-liquid water mixtures and several major experimental programs that have examined the behavior of radionuclides in LWR containment buildings (e.g., the PHEBUS tests in France and the DEMONA tests in Germany) have been reviewed and found not to be generally applicable to the HTGR reactor building. However, system codes developed for analysis of fission product behavior in LWR containments, such as MELCOR, may be useful, providing HTGR specific input data are available.

New technology development activities need to be defined for characterizing radionuclide transport in the reactor building for the accident scenarios expected to be postulated for the HTGR. Data are needed for the condensation, settling, and plateout of iodine, cesium, srontium, tellurium, and silver on reactor building materials of construction. The effects of temperature, coolant chemistry, surface state, and aerosol sizes and concentration need to be treated explicitly. The chemical forms of the key radionuclides need to be determined with particular attention to the effects of coolant chemistry on composition. A test plan needs to be developed and executed. The radionuclides of interest are iodine, cesium, srontium, tellurium, and silver. 


\section{ISSUES FOR RESOLUTION}

The information provided in this white paper is intended to serve as the basis for interaction with the NRC staff. Section 1.3 introduced current issues that require interactions with the NRC regarding design and licensing of HTGR mechanistic source terms being considered for the NGNP.

The NGNP Project is seeking (1) NRC's general concurrences and/or comments on the adequacy of the planned event-specific mechanistic source term approach and (2) to obtain feedback from the NRC on any issues that have the potential to significantly impact the effort and schedule to prepare a COL application for a first-of-a-kind HTGR plant under the NGNP Project. The following are specific areas where agreement on the NGNP Project's approach to calculate event specific mechanistic source terms is being sought:

- Agreement that the definition of event specific mechanistic source terms for the HTGR is acceptable.

- Agreement that the approach to calculate event specific mechanistic source terms for the HTGR technology is acceptable, subject to validation of the design methods and supporting data that form the bases of the calculations.

Specifically, this approach analyzes a functional containment comprising several barriers that limit the release of radionuclides to the environment (defined herein as the source term) for each postulated event, including normal operating conditions, abnormal operating conditions and accident conditions. The multiple barriers include individual fuel particle kernels and coatings, the fuel matrix and fuel element graphite, the helium pressure boundary (primary circuit), and a vented low-pressure reactor building. ${ }^{i}$ Design methods for determining radionuclide source terms, which include analytical tools used to calculate the performance of each of these barriers during radionuclide transport under eventspecific conditions, are defined and supported by testing and analysis. These analytical tools are applied in calculations for normal operating conditions, abnormal operating conditions, DBA conditions, and DBDA conditions:

- Generation and transport of each radiologically significant species of fission product from the fuel kernel, through the TRISO particle coatings and fuel element graphite and into the reactor coolant as a function of as-manufactured quality of the TRISO fuel coatings (including heavy metal contamination) and postulated in-service and accident condition coating failure rates as a function of fuel burnup, power level, temperature (including time at temperature), and, where applicable, air and water contamination.

- The concentration and form of each radiologically significant species of radionuclide in the primary circuit (those released from the fuel elements) under steady-state full power and temperature operating conditions, including circulating activity and plateout of condensable radionuclides on primary circuit components; the effects of dust generation, fallout, and radionuclide absorption; radionuclide half life; and operation of the helium purification system.

- The concentration and form of each radiologically significant species of radionuclide in helium released from the helium pressure boundary under depressurization events as a function of time considering the location and time-dependent rate of coolant release, reentrainment of accumulated dust, liftoff of plated-out radionuclides, and the effects of time-dependent air and/or moisture ingress on these parameters.

i. The HTGR reactor building includes the cavities enclosing the reactor, steam generator, and intermediate heat exchanger (where used depending on the plant configuration), and other volumes in the vented low-pressure reactor building. There may be dampers located between the cavities and the other volumes that permit free flow from the cavities to the other volumes but restrict flow from the other volumes to the cavities. 
- The effects of radionuclide form, condensation, settling, vent-path configuration, and vent filtering, if any, on the time-dependent calculation of radionuclide transport through the reactor building and the source term release to the atmosphere for each event.

- Agreement on the acceptability of the approach of the planned fission product transport tests of NGNP/ AGR Fuel Development and Qualification Program, as supplemented by the existing irradiation and post-irradiation heating data bases, to validate these fission product transport analytical tools.

For the issues summarized above, it is requested that NRC reviewers either confirm that the plans for addressing the issues are generally acceptable, or identify additional information needs of the NRC or any areas in which the NRC believes that plans will not be sufficient to address applicable regulatory requirements and guidance. 


\section{REFERENCES}

American Nuclear Society (ANS)-53.1, 2009, "Nuclear Safety Criteria and Safety Design Process for Modular Helium-Cooled Reactor Plants," ANSI/ANS-53.1-200X. American Nuclear Society, Standards Committee, 2009 (Draft for Initial NFSC Review).

Ball, S. J., and S. E. Fisher, 2008, "Next Generation Nuclear Plant Phenomena Identification and Ranking Tables (PIRTs) - Volume 1: Main Report," NUREG/CR-6944, Vol. 1 (ORNL/TM- 2007/147, Vol. 1), Oak Ridge National Laboratory, March 2008a (and additional volumes).

Ball, S. J., et al., 2008, “Next Generation Nuclear Plant Gap Analysis Report,” ORNL/TM-2007/228, Oak Ridge National Laboratory, July 2008.

Borchardt, G., B. Hürttlen, and G. Pott, 1982, "Experiment FRJ2-P24 Bestrahlungsbericht," Interner Bericht KFA-ZBB-IB-19/82, Kernforschungsanlage Jülich GmbH, Jülich, Federal Republic of Germany, August 1982.

DiNunno, J. J. et al., 1962, "Calculation of Distance Factors for Power and Test Reactor Sites," Technical Information Document (TID-14844), U.S. Atomic Energy Commission, 1962.

EPA, 1992, "Manual of Protective Action Guides and Protective Actions for Nuclear Incidents," EPA-400-R-92-001, Environmental Protection Agency, May 1992.

General Atomics, 1975, "GASSAR-6, General Atomic Standard Safety Analysis Report," February 5, 1975 (NRC Docket STN 50-534).

Hanson, D. L., 2002, "Plate out Phenomena in Direct-Cycle High Temperature Gas Reactors," EPRI Report 1003387, EPRI, June 2002.

Hanson, D. L., 2004, "A Review of Radionuclide Release from HTGR Cores during Normal Operation," EPRI Report 1009382, EPRI, February, 2004a.

Hanson, D. L., and A. S. Shenoy, 2006, "In-pile Loop Tests to Validate Fission Product Transport Codes," Proceedings HTR2006: 3rd International Topical Meeting on High Temperature Reactor Technology, October 1-4, 2006, Johannesburg, South Africa.

Hoinkis, E., 1983, “Transport of Fission Products In Matrix and Graphite,” Proceedings of a Colloquium held at the Hahn Meitner Institut Berlin from 9 to 11 November 1981, HMI B372, June 1983.

IAEA, 1997, "Fuel Performance and Fission Product Behavior in Gas Cooled Reactors," IAEA-978, International Atomic Energy Agency, November 1997.

INL, 2008, "Technical Program Plan for the Next Generation Nuclear Plant/Advanced Gas Reactor Fuel Development and Qualification Program" INL/EXT-05-00465, Rev. 2, Idaho National Laboratory, July 2008.

INL, 2009, “NGNP Licensing Plan,”PLN-3202, Rev.0, Idaho National Laboratory, June 26, 2009.

INL, 2010, "Fuel Qualification White Paper" INL/EXT-10-17686, Idaho National Laboratory, July 2010.

Keshaw, J and H. van der Merwe, 2006, "GETTER, A Model for Fission Product Release from Spherical HTR Fuel Elements," 3rd International Topical Meeting on High Temperature Reactor Technology, Johannesburg, South Africa, October 1-4, 2006, Paper No. C00000095.

Martin, R.C., 1993, "Compilation of Fuel Performance and Fission Product Transport Models and Database for MHTGR Design," ORNL/NPR-91/6, Oak Ridge National Laboratory, October 1993.

Minato, K., et al., 2000, "Fission Product Behavior of Individual Coated Fuel Particles for High Temperature Gas-Cooled Reactors," Nucl. Tech., 131, July 2000, pp. 36-47. 
Morris, R. N., et al., 2004, “TRISO-Coated Particle Fuel Phenomenon Identification and Ranking Tables (PIRTs) for Fission Product Transport Due to Manufacturing, Operations, and Accidents-Main Report,” NUREG/CR-6844, Vol. 1, Nuclear Regulatory Commission, Washington, DC, July 2004 (and additional volumes).

NUREG-0800, 1987, Revised 2007, "Standard Review Plan for the Review of Safety Analysis Reports for Nuclear Power Plants: LWR Edition," U.S. Nuclear Regulatory Commission, Office of Nuclear Reactor Regulation, Rev. 2, June 1987, Revised March 2007.

NUREG-1338, 1989, "Preapplication Safety Evaluation Report for the Modular High Temperature Gas-Cooled Reactor,” draft, U.S. Nuclear Regulatory Commission, March 1989.

NUREG-1338, 1995, "Preapplication Safety Evaluation Report for the Modular High Temperature Gas-Cooled Reactor," draft copy of the final report, U.S. Nuclear Regulatory Commission, December 1995.

NUREG-1465, 1995, “Accident Source Terms for Light-Water Nuclear Power Plants,” Soffer, L., et al., U.S. Nuclear Regulatory Commission, Office of Nuclear Reactor Regulation, February 1995.

PBMR, 2006, Letter from E. G. Wallace (PBMR) to C. Lui (NRC), "Submittal of PBMR Preapplication Papers.” PBMR (Pty) Ltd., dated May 1, 2006.

Petti, D., 2010, “Advanced fuel reaches 19 percent peak burnup,” Nuclear News, 53(1), January 2010, pp. 84-85.

Philadelphia Electric Company, 1964, Peach Bottom Atomic Power Station, Final Hazards Summary Report, NP-9115, Philadelphia Electric Company, March 1964.

Public Service Company of Colorado, 1991, "Fort Saint Vrain Unit No. 1 Updated Final Safety Analysis Report,” Rev. 9, USNRC Docket No. 50-267, July 1991.

Reutler, H., and G. H. Lohnert, 1984, “Advantages of Going Modular in HTRs,” Nuc. Eng. Des., Vol. 78 pp. 129-136.

Röllig, K., 1977, "Release of Rare Fission Gases from Spherical Elements with Coated Particles," Nuclear Technology, 35, September 1977, pp 516.

SECY-01-0070, 2001, "Plan for Preapplication Activities on the Pebble Bed Modular Reactor (PBMR)," U.S. Nuclear Regulatory Commission, June 19, 2001.

SECY-02-0076, 2002, "Semi-Annual Update of the Future Licensing and Inspection Readiness Assessment," U.S. Nuclear Regulatory Commission, May 8, 2002.

SECY-02-0139, 2002, "Plan for Resolving Policy Issues Related to Licensing Non-Light Water Reactor Designs," U.S. Nuclear Regulatory Commission, July 22, 2002.

SECY-03-0047, 2003, "Policy Issues Related to Licensing Non-Light- Water Reactor Designs," U.S. Nuclear Regulatory Commission, March 28, 2003.

SECY-05-006, [2005] "Second Status Paper on the Staff's Proposed Regulatory Structure for New Plant Licensing and Update on Policy Issues Related to New Plant Licensing," January 7, 2005.

SECY-88-203, 1988, "Key Licensing Issues Associated with DOE Sponsored Advanced Reactor Designs, " V. Stello, Jr., Executive Director for Operations, U.S. Nuclear Regulatory Commission, July $15,1988$.

SECY-93-092, 1993, "Issues Pertaining to the Advanced Reactor (PRISM, MHTGR, and Process Inherent Ultimately Safe [PIUS]) and CANDU 3 Designs and Their Relationship to Current Regulatory Requirements,” U.S. Nuclear Regulatory Commission, April 8, 1993. 
SECY-97-171, 1997, “Consideration of Severe Accident Risk in NRC Regulatory Decisions," U.S. Nuclear Regulatory Commission, July 30, 1997

Stoker, C., et al., 2008, "PBMR Radionuclide Source Term Analysis Validation Based On AVR Operating Experience," Proceedings of the 4th International Topical Meeting on High Temperature Reactor Technology, September 28 - October 1, 2008, Washington, D.C.

Stone \& Webster Engineering Corp., 1992, "Preliminary Safety Information Document for the Standard MHTGR,”HTGR-86024, Rev. 13, September 1992.

U.S. NRC, 1977, "Partial and Preliminary Draft, Interim Safety Evaluation Report Related to the Review of the GASSAR-6 Nuclear Steam Supply System, General Atomics Company," NRC Docket No. SN 50-535, June 28, 1977.

U.S. NRC, 1986, "Safety Goals for the Operations of Nuclear Power Plants: Policy Statement," 51 Federal Register 30028, August 21, 1986.

U.S. NRC, 1999, "Use of Alternative Source Terms at Operating Reactors," 64 Federal Register 71998, December 23, 1999.

U.S. NRC, 2002, “NRC Staff's Preliminary Findings Regarding Exelon Generation's (Exelon's) Proposed Licensing Approach For The Pebble Bed Modular Reactor (PBMR)," March 26, 2002.

van der Merwe, J.J, 2004, "Development and Validation of Fission Product Release Models and Software at PBMR," 2nd International Topical Meeting on High Temperature Reactor Technology, Beijing, China, September 22-24, 2004, Paper \# C18.

van der Merwe, J.J., 2008, “A Method to Evaluate Fission Gas Release During Irradiation Testing of Spherical Fuel," Proceedings of the 4th International Topical Meeting on High Temperature Reactor Technology, September 28-October 1, 2008, Washington, DC, HTR2008-58184

van der Merwe, J.J., 2009, "Evaluation of Silver Transport through SiC During the German HTR Fuel Program.," Journal of Nuclear Materials, Volume 395 (2009), pp 99-111, December 2009

van der Merwe, J.J. and I. Clifford, 2008, "Development and Application of the PBMR Fission Product Release Calculation Model," Nuclear Engineering and Design, 238 (2008), pp 3092-3101

van der Merwe, J.J. and J.H. Venter, 2009, ““"A Method to Evaluate Fission Gas Release During Irradiation Testing of Spherical Fuel," Journal of Engineering for Gas Turbines and Power, Volume 131, Issue 5, September 2009.

van der Merwe, J.J. and P.P. Coetzee, 2007, "Development of a Model to Predict Fission Product Behavior in Spherical Fuel Elements During Water Ingress Events," Nuclear Engineering and Design, Volume 237 (2007) pp 47-53, January 2007. 


\section{Appendix A}

\section{A Brief History of High Temperature Gas-Cooled Reactor Development}




\section{Appendix A \\ A Brief History of High Temperature Gas-Cooled Reactor Development}

To date, seven high temperature gas-cooled reactor (HTGR) plants have been built and operated worldwide as depicted in Figure A-1. The first was the 20 MWth Dragon test reactor in the United Kingdom. Dragon was followed by construction of two relatively low-power prototype plants: the 115 MWth Peach Bottom Unit 1 (prismatic core with cylindrical fuel elements) in the United States and the 46 MWth Arbeitsgemeinschaft Versuchsreaktor (AVR; pebble bed core) in Germany. These two reactors demonstrated electricity generation with a HTGR using the Rankine (steam) cycle. These plants were followed by construction of two mid-size steam cycle plants: the 842 MWth Fort St. Vrain plant in the United States, and the 750 MWth THTR (Thorium High Temperature Reactor) in Germany. Two additional HTGR test reactors have recently been constructed and are successfully operating: the 30 MWth High Temperature Test Reactor (HTTR) in Japan (prismatic core) and the 10 MWth High Temperature Reactor (HTR-10) in China (pebble bed core), with design reactor outlet temperatures of $950^{\circ} \mathrm{C}$ and $700-950^{\circ} \mathrm{C}$, respectively. In addition to demonstrating the use of helium coolant (with outlet temperatures as high as $950^{\circ} \mathrm{C}$ ) and graphite moderator, these plants have also successfully demonstrated coated particle fuel.

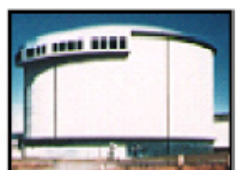

DRAGON

20 MWt prismatic

$750^{\circ} \mathrm{C}$

(UK)

1963-1976

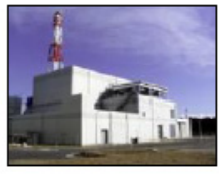

HTTR

$30 \mathrm{MWt}$ prismatic

$950^{\circ} \mathrm{C}$

(Japan)

1998-present

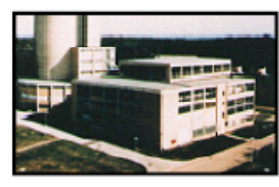

AVR

46 MWt pebble bed $>900^{\circ} \mathrm{C}$

(FRG)

$1967-1988$

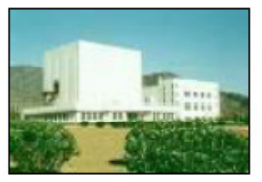

HTR-10

10 MWt pebble bed

$700-950^{\circ} \mathrm{C}$

(China)

2003-present

Experimental Reactors
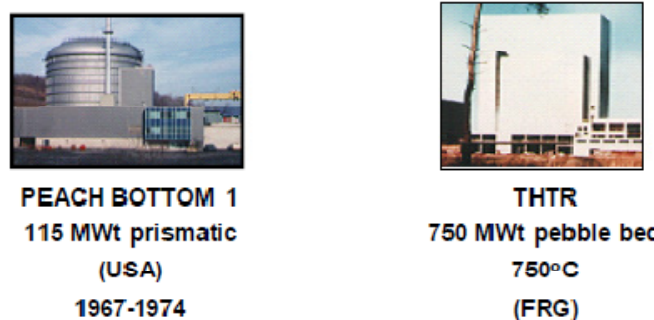

THTR

750 MWt pebble bed

$750^{\circ} \mathrm{C}$

(FRG)

1986-1989

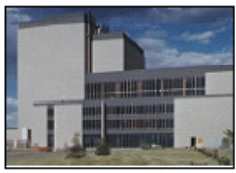

FORT ST. VRAIN

842 MWt prismatic

$\sim 800^{\circ} \mathrm{C}$

(USA)

1976-1989

Commercial Scale Demonstrations

Figure A-1. Summary of experimental and commercial scale HTGR installations.

In the 1970s, HTGR designers at General Atomics developed large prismatic block designs based on the technologies used in the Fort St. Vrain Nuclear Generating Station. The power levels of these designs ranged from 2000 to $4000 \mathrm{MWth}$. Construction permit applications for these designs were submitted to the NRC by utility customers. Regulatory review, including construction permit safety evaluation reports and an ACRS letter, was underway prior to cancellation of the projects in the late 1970s. 
In the 1980s, HTGR designers at the German company INTERATOM (later Siemens), under license to HRB, the designer of the AVR and THTR, developed a new pebble bed design that modified the reactor system in such a way that the decay heat could be removed passively under all circumstances, and the need for active emergency core cooling systems could be eliminated. The resulting design was called the HTR Modul (Reutler and Lohnert 1984). For typical reactor designs, the reactor core height and diameter are almost equal for neutron economy reasons. However, the core height in the HTR Modul was three times larger than the diameter. The advantage of this core geometry is that the decay heat can be removed radially and fully passively; the disadvantages are increased neutron leakage and a higher core flow resistance. Unlike the other HTGR designs, the HTR Modul was not intended exclusively for electricity production; other possible missions envisioned were heat and power co-generation, process heat and/or steam, district heating, etc.

The U.S. modular HTGR concept began in 1984 when Congress challenged the HTGR industry to investigate the potential for using HTGR technology to develop a "simpler, safer" nuclear power plant design. The goal was to develop a passively safe HTGR plant that was also economically competitive. To maintain the coated-particle fuel temperatures below damage limits during passive decay heat removal, the core's physical size had to be limited; the maximum reactor power capacity was found to be about 200 MWth for a solid, cylindrical core geometry. However, this rating was projected to not be economically competitive for electric power generation. This judgment led to the development of an annular core concept to enable larger cores with increased power capacity - currently up to $600 \mathrm{MWth}$. The annular core design was applied to both the pebble bed core and to the prismatic core designs. This work, combined with the extensive experience in HTGR technology and fuel fabrication in the German plants, forms the basis for the current generation of HTGRs.

In the period from early 1980 to the time of this writing, HTGR designs applying the pebble bed and prismatic reactor designs have been developed and/or deployed by the United States (MHTGR, NPR, Exelon, GTMHR), Russia (OKBM), South Africa (DPP, PBMR), France (Antares), Germany (HTR 100, HTR 500), China (HTR), and Japan (HTTR). Japan and China have each built and operated test reactors - the Chinese built the pebble bed-based HTR-10 and the Japanese built the prismatic-based HTTR. The Chinese have plans to commercialize the HTR-10 as a 250 MWth modular design. The Japanese have demonstrated operation of the HTTR at reactor outlet temperatures up to $950^{\circ} \mathrm{C}$.

In FY 2006, the Department of Energy initiated the NGNP Project at INL as directed by the 2005 Energy Policy Act. The objective of the NGNP Project is to commercialize the HTGR technology for application in the U.S. and internationally. In FY 2007 preconceptual designs of pebble bed and prismatic based plants were developed. These plants were designed for production of electricity and hydrogen with reactor ratings that varied from 500-600 MWth and reactor outlet temperatures of 900 to $950^{\circ} \mathrm{C}$. These designs were based on prior work on the PBMR DPP, the General Atomics GT-MHR and MHTGR, and the AREVA Antares designs. Subsequent to the preconceptual design work, significant interaction with potential industrial end users of the HTGR technology and completion of trade studies concluded that the HTGR should be viewed as a source of high temperature process heat that can be used to meet the energy needs of industry in several forms such as electricity, steam, high temperature gas, hydrogen, and oxygen. This work has refined the configurations and operating conditions of the pebble bed and prismaticreactor-based plants to ensure they meet the energy needs of industry.

Appendix B summarizes various HTGR configurations proposed by the suppliers. The reactor designs in these configurations cover the power range of 200-600 MWth with reactor outlet temperatures in the range $700-800^{\circ} \mathrm{C}$. These configurations and operating conditions were selected by the suppliers to reduce technical and licensing risks to implementation of the first-of-a-kind plant but still meet a reasonable range of potential end-user near-term energy needs. The NGNP Project activities (e.g., the research and development and licensing preapplication discussions with the NRC), however, will continue to support developing the HTGR technology to its ultimate capabilities as defined in the FY 2007 preconceptual 
design work. This supports completion of development, licensing, construction, and demonstration of the technical and economic viability of applying the HTGR technology designs to as wide a range of industrial applications as achievable. 


\section{Appendix B}

\section{Plant Configurations}




\section{Appendix B Plant Configurations}

Figure B-1 shows the pebble bed reactor with a cylindrical core supplying a steam generator in the primary loop. Other heat transport configurations include a gas-to-gas intermediate heat exchanger either in parallel or series with the steam generator for supply of hot gas to the process.

As is typical with these high temperature gas-cooled reactor (HTGR) designs, the core is surrounded by thick graphite layers that act to support sustained nuclear fission and containment of the neutrons produced from fission. These are the side, top, bottom, and center reflectors shown on the figure. The nuclear reaction is controlled with control rods that penetrate the side reflectors from the top. The pebbles make up the core that is located within the cylinder formed by the side reflectors. The core and reflectors are contained within a core barrel. The reactor vessel is the primary structural and pressure-retaining component of the reactor. Lower temperature helium coolant enters the core at the top, flows down through the core and exits at the bottom through the inner section of the annular cross vessel to the heat transport system. The annulus between the inner and outer vessel wall is the return flow path for helium from the heat transport system to the reactor. The helium flows up through an annulus between the core barrel and the reactor pressure vessel into the upper plenum and then down through the core.

The reactor vessel is uninsulated and surrounded by the reactor cavity cooling system which removes heat from the core and graphite in the event of loss of forced cooling through the core. The reactor cavity cooling system may contain active cooling systems during normal operation (e.g., water-cooled walls), but it is effective in maintaining acceptable core temperatures under all design basis accident conditions without any active system functioning.

The pebble bed reactor is refueled on-line. The fuel-bearing pebbles enter the core through three lines offset by 120 degrees at the top of the vessel. Over a period of a few months, each pebble travels down the core and exits from the bottom of the vessel. Each pebble is then

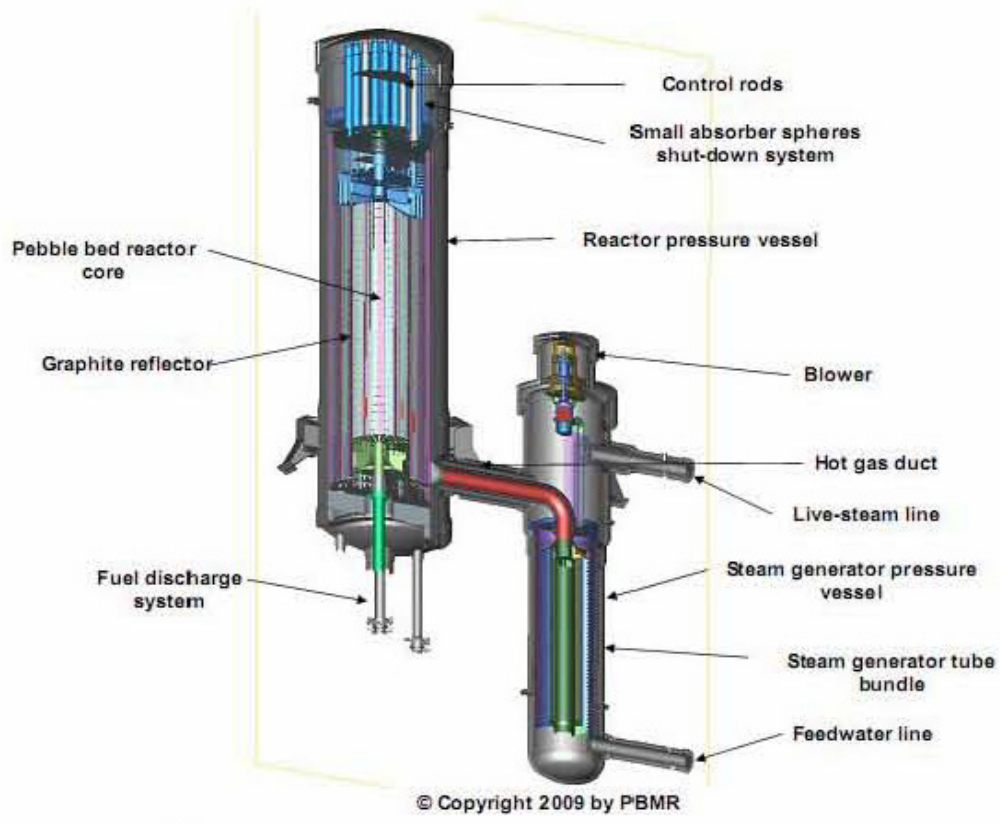

Courtesy of Pebble Bed Modular Reactor (Pty) Ltd.

Figure B-1. Current PBMR core design and plant configuration. examined in the plant fuel handling system to determine if it has reached its burn-up limit or is damaged. In these cases, it is removed from the system and a fresh pebble is inserted. Otherwise, the pebble is returned for another pass through the core. A typical pebble will make several passes through the core. 
A typical prismatic annular core reactor design is shown in Figure B-2. The fuel elements in this design are hexagonal-shaped blocks that contain fuel compacts in which the fuel particles are distributed. These blocks also contain flow passages for the helium coolant. The blocks are stacked (10 blocks high) and arranged in two to three annular rings depending on the power level of the reactor. The reactor is controlled with control and safety rods that penetrate the fuel blocks and the outer reflectors. The helium enters the reactor in the outer annulus of the cross vessel at the lower end of the reactor vessel. The coolant flows up through channels within the annulus between the core barrel and the reactor vessel to the upper plenum, providing insulation and cooling of these components. The helium flows down through the core into the lower plenum and exits the reactor in the center of the annular cross vessel. The cross vessel is connected to the heat transfer elements of the heat transport system, which can include a steam generator and/or a gas-to-gas intermediate heat exchanger. Similar to the pebble bed design, the reactor vessel is uninsulated and is surrounded by the reactor cavity cooling system. The reactor can be combined with a steam generator for power production using a conventional Rankine cycle or with a gas turbine for power production using a Brayton cycle. An intermediate heat eschanger can also be provided for production of process heat.

The prismatic reactor is refueled off-line. The refueling is performed using special refueling machines and tooling through access ports in the reactor vessel head. The prismatic fuel blocks and reflector blocks can be replaced or rearranged during refueling. The reactor vessel head is not removed during refueling or other normal conditions of the plant.
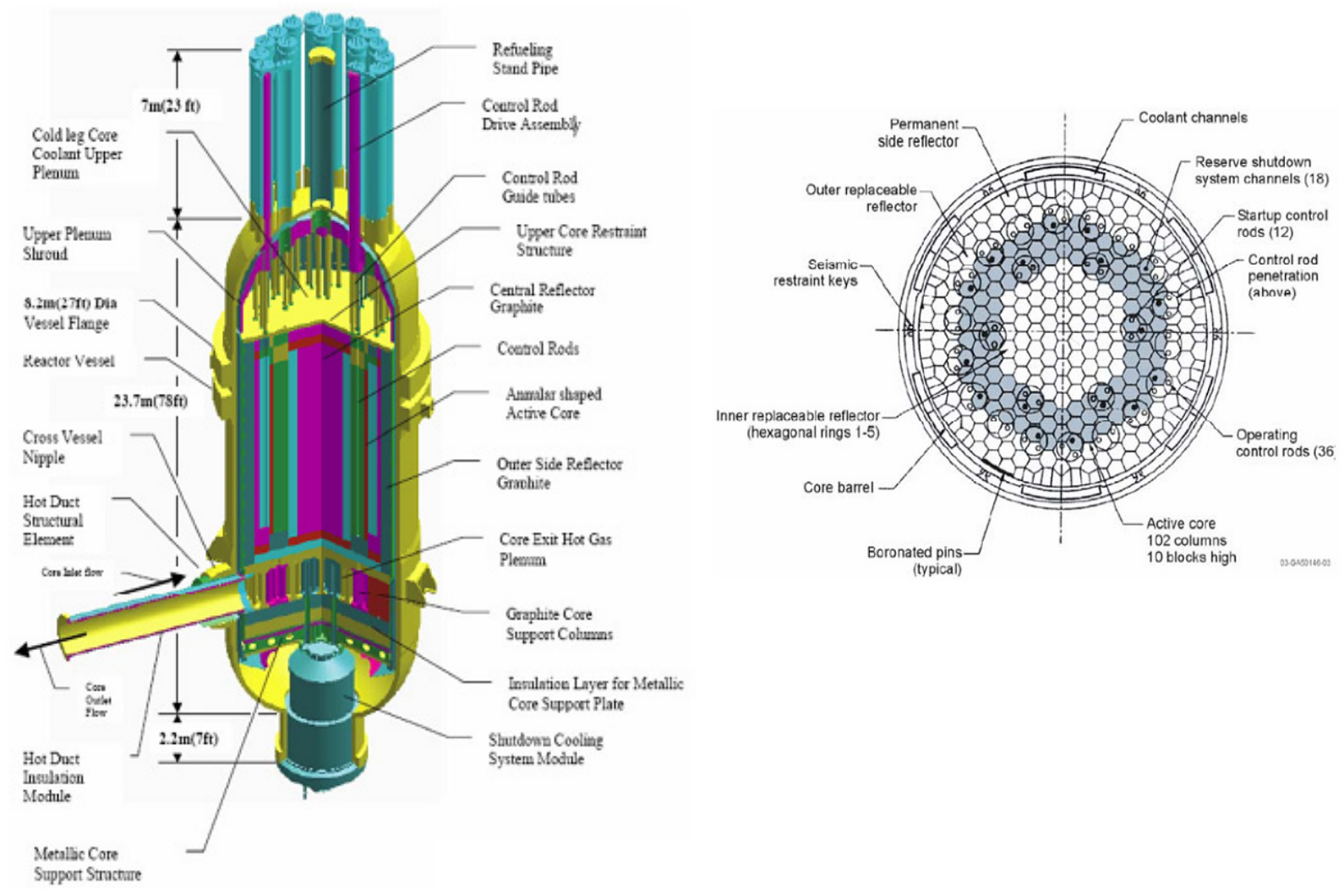

Figure B-2. Prismatic block reactor. 
Figure B-3 and Figure B-4 show conceptual arrangements of the reactor, heat transport system, reactor cavity and reactor building for the pebble bed and prismatic reactor concepts. Figure B-3, in contrast to Figure B-1, shows the pebble bed reactor combined with an intermediate heat exchanger for process heat applications. Figure B-4 shows the prismatic reactor combined with a Brayton cycle gas turbine for power generation. Defining features of the arrangements include:

- No external helium coolant piping or circulators. The transport of helium coolant to and from the heat transport system is via the cross vessel, which is of the same construction as the reactor vessel and vessels containing the heat transport system. The helium circulator is contained within the heat transport system vessel.

- Significant structural separation of the reactor and the heat transport system in lower cavities that are in turn separated from the below grade reactor building. Design features such as dampers permit flow from the reactor and heat transport cavities to the reactor building but prevent back flow from the reactor building to these cavities. This limits the potential for significant air ingress in large breaches of the helium pressure boundary since the helium released from that system purges the air from the reactor and heat transport cavities, leaving an inert helium-rich environment in these areas and no driving force for air to enter the compartments.

- Large areas and volumes within the reactor and heat transport system cavities and in the reactor building for condensation, settling, and plateout of radionuclides released from the primary circuit.

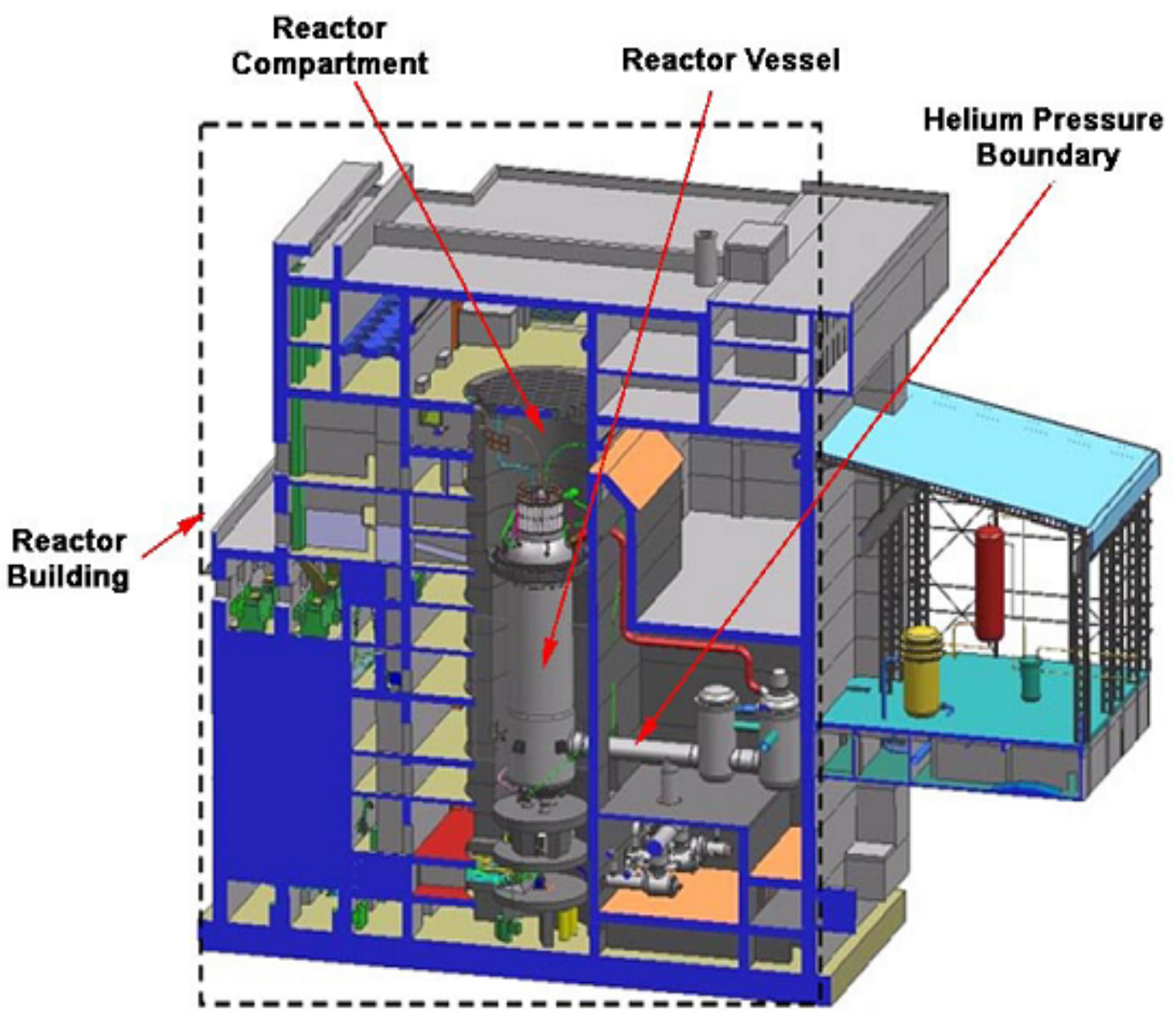

Figure B-3. Pebble bed modular reactor building conceptual configuration. 


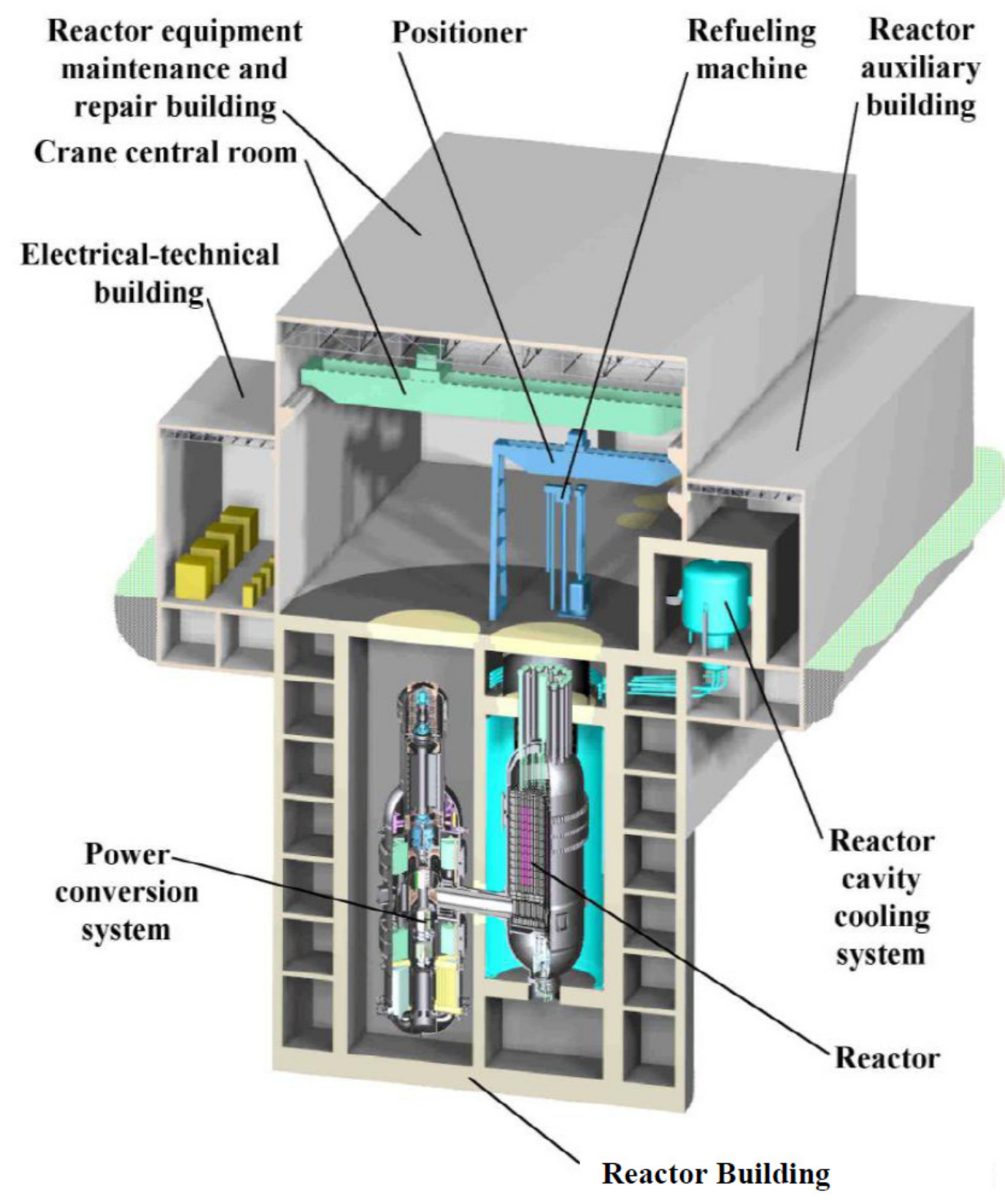

Figure B-4. Prismatic reactor building conceptual configuration. 


\section{Appendix C}

\section{Detailed Discussion of Fission Product Transport and Retention in the HTGR}




\section{Appendix C \\ Detailed Discussion of Fission Product Transport and Retention in the HTGR}

\section{C-1. INTRODUCTION}

Section 4.4 of this white paper presents a summary-level discussion of how the various aspects of fission product transport and retention in the high temperature gas-cooled reactor (HTGR) are applied in the calculation of event-specific mechanistic source terms. This appendix provides a more detailed discussion of radionuclide transport and retention in the HTGR core, including the available data characterizing fission product transport. Information is presented regarding the current understanding of the physical and chemical phenomena that take place in the core, the manner in which the data that support this understanding have been obtained, and how these phenomena are modeled to calculate mechanistic source terms. References that provide even more detailed information are cited.

Significant data on radionuclide transport and retention in HTGRs have been assembled over several decades of testing programs, and the basic approach to modeling these phenomena is well established. However, the transport and retention phenomena are complex, and in some of the existing models the uncertainties are larger than desired. Additional technology development, described in Section 5 of this white paper, is needed to more completely characterize the phenomena and to adequately validate the models to be used.

The following five barriers to fission product radionuclide release are reviewed:

1. The fuel particle kernel

2. The silicon carbide and pyrocarbon coatings of the fuel particle

3. The fuel matrix and fuel element graphite

4. The helium pressure boundary (primary circuit)

5. The reactor building.

Figure C-1 illustrates the HTGR fission product retention system.

The most important consideration in predicting the fission product release rates from an HTGR core is to predict the in-service performance of the TRISO-coated fuel particles. However, it is inconsistent with the practice of defense in depth to rely exclusively on the fuel particle coatings for fission product retention. Consequently, the effectiveness of the other fission product transport barriers also needs to be quantified. The following discusses the characteristics in all five of the barriers to fission product transport from the fuel through the reactor building.

While the actual radionuclide transport phenomena in an HTGR core are complex and remain incompletely characterized, the basic approach is, as mentioned above, well established. Radionuclide transport in the core materials is essentially treated as a transient solid-state diffusion problem with various modifications to account for the effects of irradiation and heterogeneities in the core materials, as well as radioactive decay of the radionuclides of interest. The point of departure is Fick's First Law of Diffusion, which in slab geometry simply postulates that the diffusive flux is proportional to the negative concentration gradient, with the proportionality constant being the diffusion coefficient. This approach is applied to modeling of radionuclide transport in the fuel kernel, in the particle coatings, in the fuel matrix, and (in the case of the prismatic core design) in the fuel element graphite. 


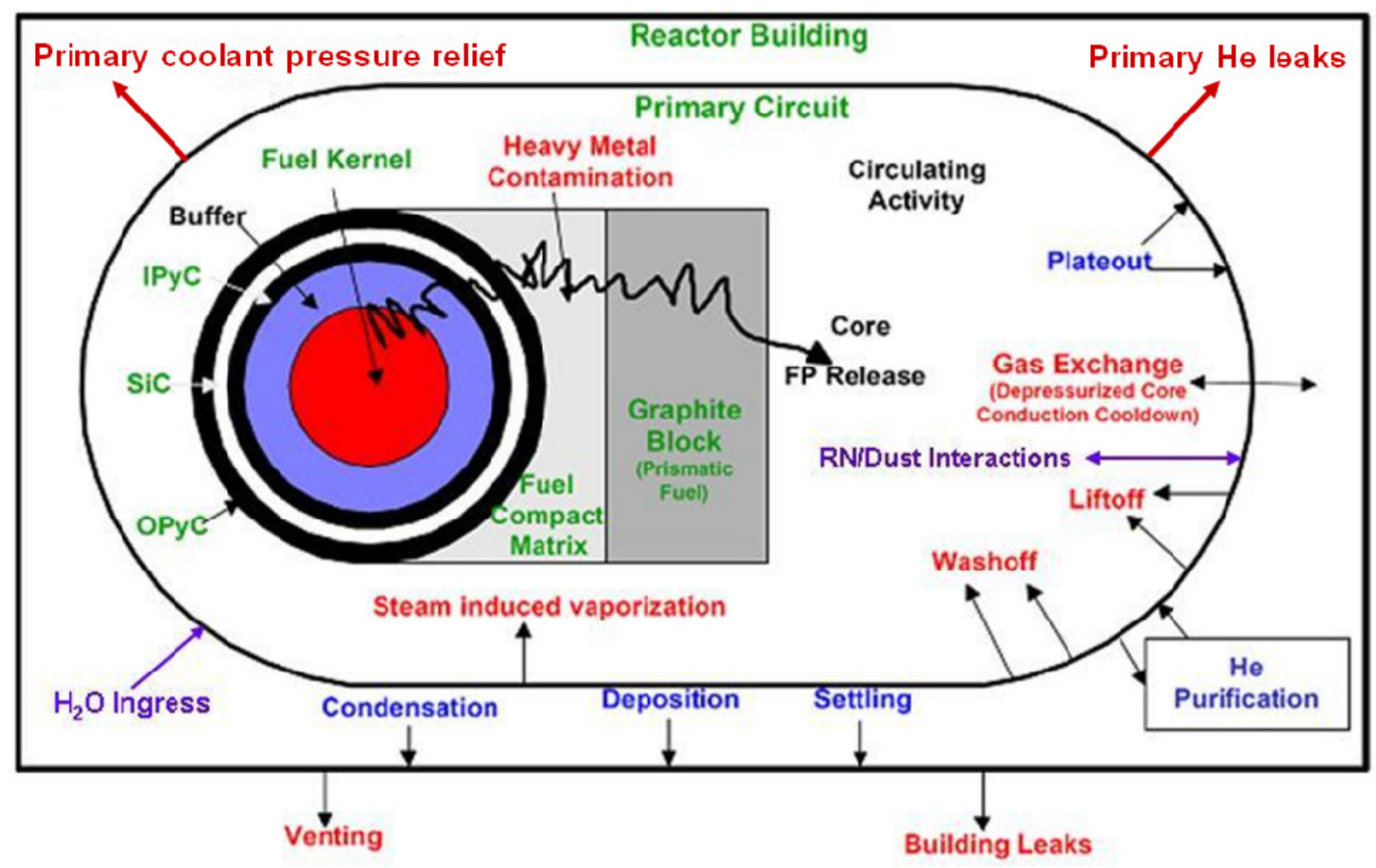

Figure C-1. HTGR radionuclide retention system.

\section{C-2. TRISO FUEL PERFORMANCE}

The principal factors that affect the potential release of radionuclides from the fuel include:

- The as-manufactured quality of the fuel

- The performance of the fuel during normal operation and under accident conditions

- Maintaining fuel service conditions under normal operating and accident conditions to ensure that fuel performance requirements are met.

Quantifying these factors and providing the data required to demonstrate acceptable fuel performance and validate fuel performance and fission product transport computer codes is the principal focus of the Advanced Gas Reactor (AGR) Fuel Qualification Program (INL 2008).

The fundamental characteristics of ceramic-coated particle fuel for HTGRs have been investigated internationally for five decades, and several countries, including the U.S., Germany, and Japan, have conducted extensive fuel development and qualification programs. These programs have identified and quantified a number of mechanisms that can affect the capability of the coated fuel particles to retain radionuclides (i.e., functional failure of the coated particle). IAEA (1997) provides a good summary along with an extensive bibliography.

The topic of TRISO fuel performance is discussed in much greater detail in the fuel qualification white paper (INL 2010). The information provided in this section regarding fuel performance is a high-level summary for quick reference.

The following failure mechanisms have been identified as capable of causing partial or total failure of the TRISO coating system under irradiation and/or during postulated accidents. 
- Pressure vessel failure of standard ("intact") particles (i.e., particles without manufacturing defects)

- Pressure vessel failure of particles with defective or missing coatings

- Irradiation induced failure of the OPyC coating

- Irradiation induced failure of the IPyC coating and potential SiC cracking

- Failure of the SiC coating because of kernel migration in the presence of a temperature gradient

- Failure of the $\mathrm{SiC}$ coating caused by fission product/SiC interactions

- Failure of the $\mathrm{SiC}$ coating caused by $\mathrm{CO} / \mathrm{SiC}$ interactions

- Failure of the SiC coating by thermal decomposition

- Failure of the SiC coating because of heavy metal dispersion in the buffer and IPyC coating layers.

The observed failure mechanisms for TRISO fuel can be categorized as structural/mechanical or thermo-chemical in nature. Failure mechanisms in both categories can be affected by the release of excess oxygen during fission and subsequent formation of carbon monoxide. Each failure mechanism listed above is discussed in detail in the "Fuel Qualification White Paper" (INL 2010), including a review of the international experimental data bases for quantifying these failure mechanisms, the underlying mechanisms, and the typical models for predicting these phenomena in reactor core design and safety analyses.

As-manufactured heavy metal contamination (i.e., heavy metal outside the coated particles) is not an in-service failure mechanism but is very important with respect to fission product release. It is an extreme case of as-manufactured coating defects whereby trace amounts of heavy metal are not encapsulated by any intact coating layers, including cases in which heavy metal contamination is contained in the fuel matrix material (analogous to "tramp uranium" in LWR fuel). Modern fuel-product specifications only allow small fractions of heavy metal contamination $\left(\sim 10^{-5}\right.$ is typical); nevertheless, it is still an important source of fission product release.

Typically, the two dominant sources of fission product release from the core are (1) as-manufactured heavy-metal contamination and (2) particles whose coatings are defective or fail in service. In addition, the volatile fission product metals (e.g., Cs, Ag, and Sr) can, at sufficiently high temperatures for sufficiently long times, diffuse through the $\mathrm{SiC}$ coating and be released from intact TRISO particles. However, it is only for silver and tritium that diffusive release from intact particles during normal operation is significant compared to release from heavy-metal contamination and from defective or failed particles.

Fission products resulting from fissions in heavy metal contamination outside of the particles are by definition not attenuated by the kernels or coatings, nor are the fission products produced in the kernels of failed particles appreciably attenuated by the failed coatings. In these cases, the fission product release must be limited by limiting the level of heavy metal contamination and the fraction of particles that are defective or fail in-service. Furthermore, as discussed later, fission product release is attenuated by the fuel element matrix/graphite in the case of the fission product metals and actinides.

\section{C-3. RADIONUCLIDE RETENTION IN THE FUEL KERNEL}

The first barrier to fission product transport and release is the fuel kernel itself. The extensive international database on radionuclide release from fuel kernels has been summarized previously in numerous review documents (e.g., IAEA 1997, Martin 1993, Hanson 2004, etc.). Numerous transport models have been proposed to correlate these experimental data, including (Rollig 1977) for spherical fuel elements. 
The release of short-lived fission gases from heavy-metal contamination and from fuel kernels is typically expressed in terms of the release rate-to-birth-rate ratio $(\mathrm{R} / \mathrm{B})$. At steady state, the $\mathrm{R} / \mathrm{B}$ ratio is numerically equal to the fractional release.

Under normal operating conditions, the kernel retains a substantial fraction $(>95 \%)$ of the radiologically important, short-lived fission gases such as Kr-88 and I-131. However, at elevated temperatures the effectiveness of the fuel kernels for retaining fission gases can be reduced. In addition, fractional releases of fission gases from exposed fuel kernels under irradiation can be enhanced if the kernel is hydrolyzed by reaction with water vapor which may be present in the helium coolant (e.g., because of a tube leak in a steam generator located in the primary helium loop). The magnitude of the effect depends upon the kernel composition, with $\mathrm{UC}_{2}$ showing the largest enhancement and $\mathrm{UO}_{2}$ showing the least. The effect for UCO is intermediate. With kernels containing uranium carbide, the water reacts to convert the carbide phase completely to oxide along with kernel swelling and increased porosity. With $\mathrm{UO}_{2}$ kernels, a hyperstoichiometric uranium oxide phase may be formed. In any case, kernel porosity is increased with enhanced fission gas release.

The fission gas release models give the R/Bs from dispersed heavy-metal contamination, bare kernels, and from failed particles under irradiation as a function of chemical element, isotope half life, temperature, and burnup. These functional dependencies are determined experimentally. At high irradiation temperatures, experimental fission gas release measurements show that the R/B is proportional to the square root of isotope half life. While this observation is consistent with a diffusive release mechanism, the actual release mechanism is more complicated. For example, some fission fragments born near the exterior surface of the kernel are released by recoil, and high-energy neutrons produce irradiation-induced defects and other structural changes. In addition, gaseous fission products may become trapped at intrinsic or irradiation-induced defects to form bubbles which themselves migrate. In fact, at lower irradiation temperatures $\left(<1,000^{\circ} \mathrm{C}\right)$ and at very high neutron fluxes, significant deviations from the square root of half life dependence are often observed. Moreover, at lower temperatures, the $\mathrm{R} / \mathrm{Bs}$ tend to plateau and become almost athermal. These effects are also taken into account in the models for the release of fission gases from the fuel kernel.

The present U.S. data-base for fission gas release from dispersed heavy-metal contamination, bare kernels, and from failed particles under irradiation is derived primarily from TRIGA reactor measurements on fuel compact matrix doped with uranium and on laser-failed, irradiated fuel particles from capsules. TRIGA measurements are confirmed and/or calibrated by in-pile measurements, in which it is assumed that R/B measured at the beginning of an irradiation test is dominated by release from contamination and that this contribution remains constant so that incremental increases in R/B during irradiation can be attributed to failed particles. The most reliable data for fission gas release under core heatup conditions were generated by post-irradiation heating of laser failed particles that were reactivated prior to heating to produce an inventory of short-lived fission gases such as 8-day I-131.

The fission gas release from failed particles is the product of the failure fraction and fractional release from a failed particle. Typically, the failure fraction is not known during the irradiation independent of the on-line $\mathrm{R} / \mathrm{B}$ measurements. The solution to this problem has been to perform a series of irradiation tests with a known failure fraction (i.e., with a well-defined fission product source). This circumstance was accomplished by seeding selected fuel compacts with a fraction (typically, 0.1-1.0\%) of DTF fuel particles, which are standard fuel kernels with a thin (typically, 10-15 $\mu \mathrm{m}$ ) pyrocarbon seal applied directly on the kernels. These seal coats fail early under neutron irradiation, providing a well-defined exposed kernel fraction. Such DTF particles have been successfully used in several tests with diverse objectives: (1) in-pile hydrolysis tests with LEU UCO fuel (HRB-17/18) in the High Flux Isotope Reactor, (2) temperature dependence of fission gas release from both unhydrolyzed and hydrolyzed LEU UCO fuel in the HFR-B1 test in HFR Petten, and (3) the COMEDIE BD-1 in-pile loop test. 
An example of fission gas release data generated in the HFR-B1 hydrolysis test is given in Figure C-2. The general response of the exposed kernel to the introduction of water vapor consists of three distinct phases: (1) a transient release of stored fission gas with a concomitant increase in the steady-state fractional release, (2) a period of constant steady-state release, and (3) upon removal of the water vapor, a monotonic decline in the fractional release to prehydrolysis values (or nearly so). Relatively complicated empirical models have been derived from the experimental data that reproduce these transient results; however, for design purposes, a simpler approach is taken in recognition that the transient release phase is short lived, and that a new steady-state $\mathrm{R} / \mathrm{B}$ is established if the water is persistent, or the $\mathrm{R} / \mathrm{B}$ returns to nearly its original value if the water is removed.

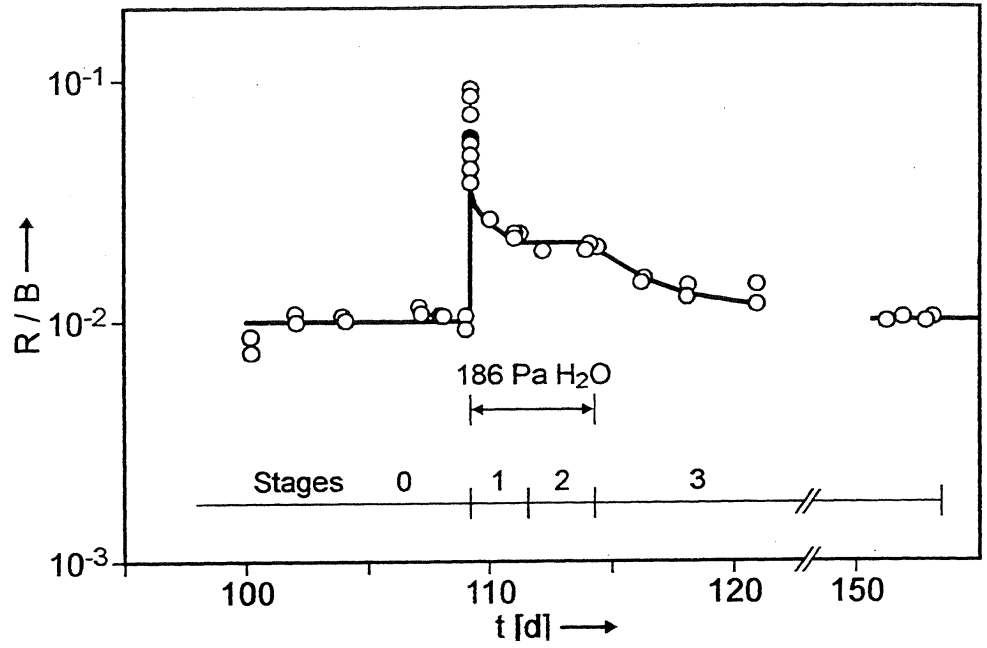

Figure C-2. Effect of hydrolysis on fission gas release.

Similar R/B behavior has been observed in hydrolysis tests conducted in support of spherical pebble fuel development for the HTR-MODUL in Germany. Fuel proof test HFR-K6, which was irradiated in the High Flux Reactor in the Netherlands, contained low-enriched, TRISO-coated $\mathrm{UO}_{2}$ fuel particles (van der Merwe, J.J. and P.P. Coetzee 2007).

Note that the technical specifications for HTGR normal plant operation will limit concentrations of oxidants in the helium to very low levels (e.g., for the Fort St. Vrain HTGR the limit was $<10$ ppm total oxidants). If the technical specification limits are reached, corrective action must be taken, including removal of the oxidants by action of the helium purification system.

There is also an extensive international database on the release of fission metals from oxide-based $\mathrm{U}$ and Th fuel kernels. Only silver, cesium, and palladium (and perhaps other noble metals) are diffusely released to a significant degree from oxide fuel kernels at normal operating temperatures. The other fission metals, including radiologically important Sr-90, are only released by fission recoil. The present data base for fission metal diffusivities in fuel kernels is derived primarily from measurements on particles irradiated in accelerated irradiation tests.

Correlations for diffusivity of metallic fission products in kernel materials include very strong burnup dependence. This burnup dependence is derived primarily from measured Cs releases from $\mathrm{ThO}_{2}$ kernels with burnups from 1-6\% FIMA. The strong burnup dependence was derived primarily from the set of measurements at $1400 \mathrm{C}$. Whether this strong burnup dependence applies to $\mathrm{UCO}$ or $\mathrm{UO}_{2}$ kernels at burnups above $10 \%$ FIMA needs further confirmation. However, based on available information, it is expected that the retention by fuel kernels of long-lived, volatile fission metals such as $\mathrm{Cs}, \mathrm{Ag}$, and $\mathrm{Sr}$ is strongly dependent upon burnup as well as temperature. 
Since there is no practical way of monitoring metal release on-line during an irradiation test, the data are obtained during post-irradiation examination. One approach is to gamma count the irradiated particles and to deduce the fractional releases by the ratios of volatile fission metals to a refractory fission metal (e.g., Ce-144) in a failed particle to the corresponding ratios in an intact particle. Another approach is to recover intact particles from deconsolidated fuel compacts, laser fail the particles, heat them isothermally over a range of temperatures (typically $1400-1700^{\circ} \mathrm{C}$ ), and measure the time-dependent fractional releases of the volatile fission metals. With both approaches, effective diffusion coefficients are derived that match the measured fractional releases.

As with the transport of fission gases in the kernel, the transport of mobile fission metals, including $\mathrm{Cs}, \mathrm{Ag}, \mathrm{Sr}$ and Eu isotopes, is undoubtedly more complicated than classical Fick's Law diffusion. The fission product speciation in the kernel changes with burnup, especially with UCO kernels as the oxygen potential changes, and these changes in chemistry could affect the mobility of oxide-forming species, including Cs and Sr. (The probable exception is silver, which appears to remain in elemental form for all kernel compositions and burnups of interest.) The release of metallic fission products is calculated with computer codes which assume that the kernel material is homogeneous. Therefore, it is necessary to determine an effective homogeneous diffusion coefficient. Use of an effective diffusion coefficient in code calculations is expected to result in the same fractional release of fission products from the fuel kernel as was observed in the measurements from which the coefficient was derived.

\section{C-4. RADIONUCLIDE TRANSPORT AND RETENTION IN THE FUEL PARTICLE COATINGS}

The second - and most important - barrier to fission product transport and release from the core is the silicon carbide and pyrocarbon coatings of each fuel particle. Both the $\mathrm{SiC}$ and $\mathrm{PyC}$ coatings provide a barrier to the release of fission gases. The SiC coating acts as the primary barrier to the release of metallic fission products because of the low solubilities and diffusion coefficients of fission metals in SiC. The $\mathrm{PyC}$ coatings are partially retentive of $\mathrm{Cs}$ at lower temperatures but provide little holdup of $\mathrm{Ag}$ and $\mathrm{Sr}$.

There are considerable international data on the transport of fission products in the $\mathrm{SiC}$ and $\mathrm{PyC}$ coatings of TRISO fuel particles (e.g., IAEA 1997). Most of these data were obtained by heating irradiated particles, and effective diffusion coefficients were deduced from the observed time histories of fission product release.

Typical post-irradiation heating results are illustrated in Figure C-3 which shows the data obtained by Oak Ridge National Laboratory (ORNL) for Japanese LEU UO ${ }_{2}$ TRISO particles from Capsule HRB-22 [Minato 2000]. A batch of 25 particles was recovered from a fuel compact and heated at $1700^{\circ} \mathrm{C}$ for 270 hours. No particle experienced complete coating failure (i.e., at least one PyC coating remained intact because complete failure of a single particle would have resulted in $\sim 4 \%$ fractional release of $\mathrm{Kr}-85$ ). The release profiles indicate that, at $1700^{\circ} \mathrm{C}, \mathrm{Ag}$ is rapidly diffusively released from intact TRISO particles, $\mathrm{Kr}$ is retained by $\mathrm{PyC}$ coatings, and $\mathrm{Cs}$ and $\mathrm{Eu}$ are slowly released as the $\mathrm{SiC}$ coating degrades.

Fission-metal transport in coatings is modeled as simple Fick's Law diffusion characterized by an effective diffusion coefficient. As with transport in the fuel kernel, radionuclide transport in the PyC and $\mathrm{SiC}$ coatings is undoubtedly more complex than homogeneous Fick's Law diffusion. The migration coefficients are generally structure sensitive, which indicates that the migration process is not a bulk diffusion process but likely a combination of lattice diffusion, grain boundary diffusion, pore diffusion, etc., complicated further by effects like irradiation-enhanced trapping and adsorption. Consequently, any quoted diffusion coefficient should be considered an "effective" diffusion coefficient, which implies that the overall migration process can be approximately described by Fick's Laws. 


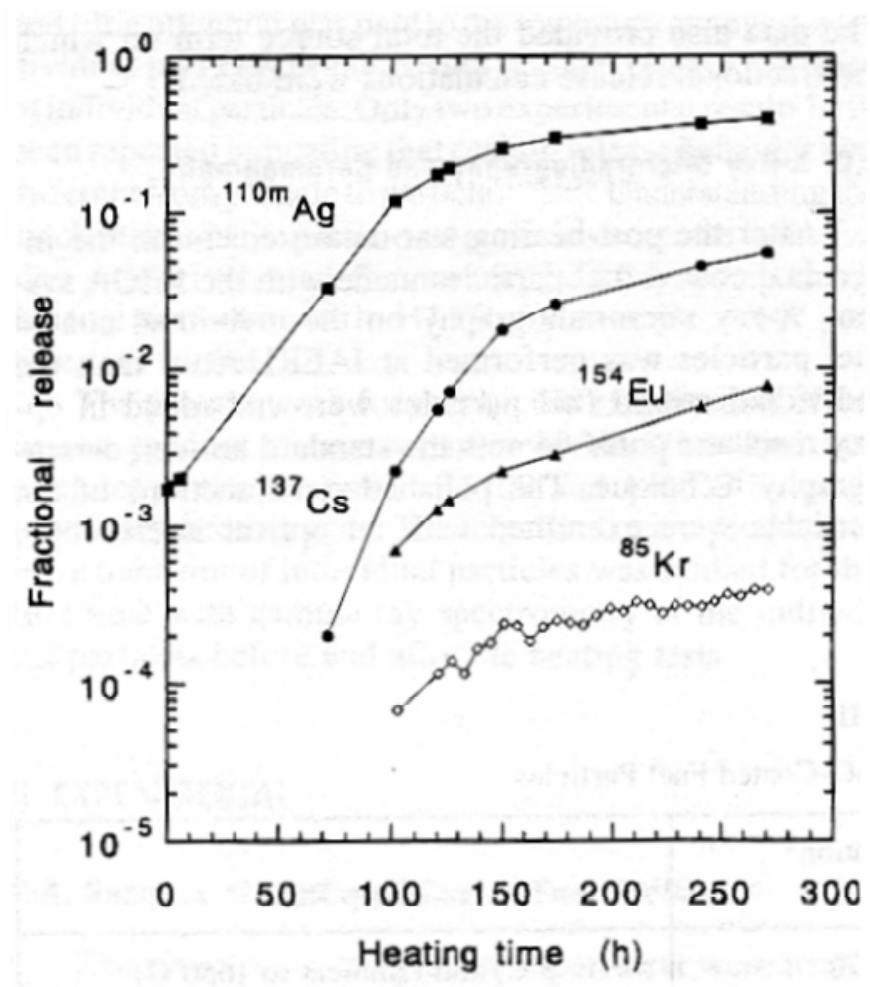

Figure C-3. Metal release during post-irradiation heating of $\mathrm{HRB}-22$ particles at $1700^{\circ} \mathrm{C}$.

\section{C-5. RADIONUCLIDE TRANSPORT AND RETENTION IN THE FUEL MATRIX AND FUEL ELEMENT GRAPHITE}

For a prismatic core, the fuel compact matrix and the fuel block graphite collectively are the third fission product transport and release barrier. For a pebble bed core, the analog is the pebble matrix, including the unfueled outer shell of the spherical pebble fuel element. Radionuclide transport in fuel matrix and fuel element graphite is treated collectively since the experimental techniques to characterize radionuclide transport in them are the same, and the radionuclide transport mechanisms are also assumed to be the same.

The fuel matrix material is relatively porous and provides little holdup of the fission gases that are released from the fuel particles. The effect is generally neglected in calculations of fission gas transport in the fuel matrix, as well as in the fuel block graphite.

However, the fuel matrix is a composite material that has a high content of amorphous carbon, and this constituent of the matrix is highly sorptive of metallic fission products, especially $\mathrm{Sr}$ and actinides. While the matrix is highly sorptive of metals, it provides little diffusional resistance to the release of fission metals because of its high interconnected porosity.

The graphite block of a prismatic fuel element, which is denser and has a more ordered structure than the fuel matrix material, is somewhat less sorptive of the fission metals than the matrix, but it is more effective as a diffusion barrier. The effectiveness of the graphite as a release barrier decreases as the temperature increases. Under typical steam-cycle core conditions, with helium coolant temperatures at the core outlet on the order of $750^{\circ} \mathrm{C}$, the fuel element graphite attenuates the release of Cs from the core by an order of magnitude, and the $\mathrm{Sr}$ is essentially completely retained. The extent to which the graphite 
attenuates Ag release is less well characterized, and there is some evidence that the retention of Ag by graphite increases as the total system pressure increases, implying gas phase transport through the interconnected pore structure of the graphite.

The international database for radionuclide transport in matrix and graphite has been summarized previously (e.g., Hoinkis 1983). The database for nuclear graphite is large in recognition of its effectiveness as a release barrier in HTGR cores. Only cesium and silver nuclides effectively migrate through the fuel element graphite at normal operating temperatures. The other fission metals, including Sr-90 and the actinides, are completely retained by the graphite during normal operation. A fraction of the Sr-90 is released under core heatup peak temperature conditions, but the actinides are still completely retained.

Basically, two types of experiments have been performed to characterize fission product transport through matrix and graphite: (1) concentration profile experiments, and (2) permeation experiments. In the first type of experiment, the concentration of a radioactively tagged metal is measured as a function of distance from the source; the test specimen geometry was usually a slab but occasionally an annulus. In the second type, the steady-state permeation rate of the metal through a test specimen was measured; in addition, the concentration profile in the test specimen was typically determined as well. For simple Fick's Law diffusion in a homogeneous material, the transport coefficients derived from the two types of experiments should be equal; when the concentration data are plotted as log concentration versus penetration depth squared, a straight line should be obtained.

In some experiments (e.g., Sr transport in British nuclear graphite), simple Fick's Law diffusion appeared to be confirmed. However, in general, the measured concentration profiles were much more complex, and a number of different transport mechanisms have been proposed, including coupled fast-path/slow-path diffusion, surface diffusion with trapping, etc. Most of the early measurements were made with unirradiated graphite. Later data indicated that the diffusivity of cesium in H-451 graphite decreased with increasing fast fluence. This suggests that neutron damage created additional traps in the graphite.

Hence, it is clear that the transport of fission metals, including $\mathrm{Cs}, \mathrm{Sr}$, and $\mathrm{Ag}$, in nuclear graphite is more complex than homogeneous Fick's Law diffusion. The present correlations for fission-metal diffusivities in core graphite are derived largely from laboratory measurements on unirradiated nuclear graphites and from profile measurements in various irradiated graphites. Additional technology development activities are needed to determine if effective diffusivity derived from permeation measurements used in a Fick's Law transport model is sufficiently accurate for core analysis purposes. These issues will be addressed in the AGR Fuel Development Program.

Fission-metal transport in the fuel compact matrix is modeled as a transient Fick's Law diffusion process with an effective diffusion coefficient. For prismatic core designs, the transient diffusion equation for cylindrical geometry is solved with an evaporative boundary condition. The analysis model assumes that sorption equilibrium prevails in the gap between the fuel compact and the fuel-hole surface of the fuel block. At equilibrium, the vapor pressure in the helium-filled gap and the solid-phase concentration on the fuel compact surface are uniquely related to one another by a sorption isotherm that is determined experimentally. For pebble bed fuel, the transient diffusion equation for spherical geometry is solved with an evaporative boundary condition.

Several different sorption isotherms have been derived by making various assumptions about the potential energy distributions of the sorption sites that lead to different functional dependencies between the gas phase partial pressure and the surface concentration. However, for the sorption of fission products on core materials, the experimental data are generally correlated with a simple Henrian isotherm (linear dependence) for low sorbate concentrations and with a Freundlich isotherm (exponential dependence) at 
higher sorbate concentrations. Functionally, the partial pressure in the gap is assumed to be the sum of the pressures calculated with the two isotherms.

The sorptivities of unirradiated and irradiated nuclear graphites and matrix materials for various fission metals and iodine have been investigated by the various international HTGR programs; the data are summarized in (IAEA 1997). The sorptivities of Cs and Sr on H-451 and H-327 graphites and over petroleum pitch matrix materials (all materials used in Fort St. Vrain) have been measured in the laboratory at partial pressures $>10^{-10}$ atm (several orders of magnitude higher than typical in-reactor partial pressures during normal operation). The sorptivities of $\mathrm{Cs}$ and $\mathrm{Sr}$ on nuclear graphites have been shown to increase with increasing fast fluence, but the effect may anneal out at high temperatures in the absence of a neutron flux. Apparently, neutron irradiation of the crystalline component causes damage that creates additional sorption sites. Consequently, the sorption isotherms have been modified to include a fast-fluence dependence which is fit to the experimental data. The sorptivity of pitch matrix is independent of fast fluence. The sorptivities $\mathrm{Cs}, \mathrm{Sr}$ and $\mathrm{Ag}$ on German thermosetting resin matrix, including A3 matrix used in the pebble bed design, have been measured and may apply to candidate U.S. resin matrix materials.

The transport of fission metals in the prismatic fuel element graphite is also modeled as transient Fick's Law diffusion with an effective diffusion coefficient and an evaporative boundary condition at the coolant interface. The graphite web of a prismatic fuel element is treated as an equivalent slab. As noted above, additional technology development activities are needed to determine if an effective diffusivity derived from permeation measurements used in a Fick's Law transport model for radionuclides in graphite is sufficiently accurate for core analysis purposes. These issues will be addressed in the AGR Fuel Development Program.

At the coolant boundary, the mass flux from the surface into the flowing coolant is given by the product of a convective mass transfer coefficient and a concentration driving force, which is the difference between the desorption pressure (expressed as a volumetric concentration) and the "free stream" or mixed mean concentration in the coolant.

The equilibrium desorption pressure in the boundary layer is calculated with a sorption isotherm (as described in the discussion of fission product transport across the fuel rod/graphite gap) and converted to a volumetric concentration using the ideal gas law. The mixed mean coolant concentration is often conservatively set to zero; alternatively, a two-dimensional model can be used that integrates the total flux into the coolant as it passes through the fuel element or core, thereby providing the coolant concentration at each local point.

For prismatic fuel elements, the mass transfer coefficient is calculated from an empirical correlation for the Sherwood number. In general, the Sherwood number is given as functions of the Reynolds, Schmidt, and Grashof numbers.

For spherical pebble bed fuel elements the approach to calculating fission product mass flux from the pebble surface into the flowing coolant is essentially the same, with appropriate adjustments for fuel geometry and for different fuel matrix material with different sorption characteristics (Keshaw 2006).

\section{C-6. RADIONUCLIDE TRANSPORT AND RETENTION IN THE HELIUM PRESSURE BOUNDARY}

The fourth transport and release barrier is the helium pressure boundary (primary circuit). Once the fission products have been transported from the core into the coolant, they are transported throughout the primary circuit by the helium coolant. The helium purification system (HPS) efficiently removes both gaseous and metallic fission products from the helium at a rate determined by the gas flow rate through 
the purification system. However, the primary purpose of the HPS is to control chemical impurities in the helium.

For the condensable fission products, the dominant removal mechanism is deposition ("plateout") on the various helium-wetted surfaces in the primary circuit (i.e., the plateout rate far exceeds the purification rate). The plateout rate is determined by the mass transfer rates from the coolant to the fixed surfaces, by the sorptivities of the various materials of construction for the volatile fission products, and by the temperatures of the surfaces. Condensable radionuclides may also be transported throughout the primary circuit sorbed on particulates ("dust") which may be present in the primary circuit. The distribution of these contaminated particulates may be considerably different from the distribution of radionuclides transported as atomic species.

The circulating and plateout activities in the primary circuit are potential sources of release to the environment in the event of helium leaks or as a result of the venting of helium in response to over pressurization of the primary circuit (e.g., in response to significant water ingress because of a steam generator tube leak in a steam cycle plant). The fraction of the circulating activity lost during such events is essentially the same as the fraction of the helium that is released, although the radionuclide release can be mitigated by pump down through the HPS if the leak rate is sufficiently slow.

A small fraction of the plateout may also be re-entrained, or "lifted off," if the rate of depressurization is sufficiently rapid. The amount of fission product liftoff is expected to be influenced by the amount of dust in the primary circuit as well as by the presence of friable surface films on primary circuit components which could possibly spall off during a rapid depressurization.

Other mechanisms that can potentially result in the removal and subsequent environmental release of primary circuit plateout activity are "steam-induced vaporization" and "washoff." In both cases, the vehicle for radionuclide release from the primary circuit is water that has entered the primary circuit. In principle, both water vapor and liquid water could partially remove plateout activity. However, even if a fraction of the plateout activity was removed from the fixed surfaces, there would be environmental release only in the case of venting of helium/steam from the primary circuit. For all but the largest water ingress events, the pressure relief valve does not lift. Moreover, the radiologically important nuclides, such as iodine and cesium, are expected to remain preferentially in the liquid water that remains inside the primary circuit. The probability of large water ingress with a gas turbine plant or a plant with an intermediate heat exchanger is much lower than for a conventional steam-cycle plant because with the former the secondary water pressures are lower than the helium coolant pressures.

A number of different phenomenological models and associated computer codes have been developed internationally to predict radionuclide transport in the primary circuits of HTGRs (IAEA 1997, Martin 1993, Hanson 2002, etc.). Typically, the practical utility of the more sophisticated models has been limited by unavailability and/or unreliability of the material property data required as input to these codes. The U.S. plateout and liftoff models and needed material property data are summarized below.

\section{C-6.1 Condensable Fission Product Plateout}

The transport and deposition of condensable radionuclides from the flowing helium coolant to fixed surfaces in the primary circuit is essentially a convective mass transfer problem (e.g., Hanson 2002). Usually, deposition is conceived as a two step process: (1) gaseous diffusion to the wall and (2) a wall effect, typically an adsorption process. The latter step is significant because numerous experiments have shown that, under certain circumstances, graphitic and metallic surfaces have a limited capacity for adsorption of certain radioactive species. In general, either the gaseous diffusion or the wall effect can be the dominant phenomenon. 
The wall effect may be simply an adsorption process whereby the active sites are confined to the surface. Alternatively, some data (primarily German) suggest that certain radionuclides, principally Ag isotopes, may penetrate into the bulk of metallic components. In any case, it is apparent that at high temperature, certain fission metals, including $\mathrm{Cs}, \mathrm{Ag}$, and $\mathrm{Sr}$ isotopes, will diffuse into the interior of graphite surfaces (e.g., the lower reflector blocks at the core exit).

Characterization of radionuclide transport in the primary circuit has involved a variety of experimental approaches: (1) laboratory sorption measurements, (2) single effects tests in out-of-pile loops, and (3) integral tests in in-pile loops.

The available sorption data for describing the deposition of condensable radionuclides on structural materials has been summarized and correlated as sorption isotherms for use in analyses. There are few data for typical primary circuit materials (e.g., Alloy $800 \mathrm{H}$, Inconel 617, etc.). With the exception of the tungsten data, these sorption measurements were made at partial pressures that are orders of magnitude higher than those predicted for the reactor during normal operation with high quality fuel (e.g., $10^{-17}$ to $10^{-13} \mathrm{~atm}$ ); consequently, the sorption isotherms derived from these data are extrapolated some four to six orders of magnitude when used in reactor analysis.

A number of experimental programs, principally in Germany and the U.S., have been performed in out-of-pile loops to characterize and correlate radionuclide plateout and liftoff phenomena; the results of these tests have been summarized in several documents (e.g., Hanson 2002). Most out-of-pile loops utilize an artificial fission product source (e.g., a graphite powder impregnated with a single radionuclide, such as stable Cs133 tagged with radioactive Cs137, located in a high temperature furnace and maintained at the requisite temperature to produce the desired coolant partial pressure). Such artificial sources raise questions about their representativeness (e.g., fission product speciation, precursor effects, chemical interactions, etc.). Several research groups have adopted innovative designs for their out-of-pile loops in an attempt to mitigate these limitations. For example, the Battelle Memorial Institute deposition loop used a slightly irradiated sample of coated particle fuel as the fission product source. The Kernforschungsanlage Julich (Nuclear Research Center, FRG) researchers that designed the two VAMPYR plateout facilities went a step further and used a small side stream of AVR helium coolant as their fission product source.

The COMEDIE BD-1 test serves an example of the type of plateout and liftoff data that can generated in an in-pile test loop [Hanson and Shenoy 2006]. The CEA COMEDIE loop was an in-pile test facility in the SILOÉ materials test reactor in Grenoble, France. The in-pile section included a fuel element, a reflector element, and a straight tube, counter flow, gas-to-gas heat exchanger/recuperator simulating the steam generator and other metallic components in the primary circuit. The BD-1 test was conducted to obtain integral test data to validate the design methods used to predict fission product release from the core and plateout in the primary circuit of a steam cycle HTGR and liftoff during rapid depressurization transients.

Upon completion of the blowdown tests, the plateout distributions along each of the heat exchanger tubes was rapidly determined by gamma scanning and by leaching followed by radiochemical analysis for the beta emitters. The BD-1 plateout distributions have been analyzed in detail and compared with predictions made using one of the plateout distribution codes used at General Atomics, PADLOC. Typical results for Cs and Ag are summarized in Figure C-4 and Figure C-5. The predicted profiles for Ag-110m and Cs-137 are within the allowable uncertainty of 10×. However, Ag sorptivity at the highest temperatures was significantly over predicted. The Ag sorption isotherms are highly uncertain, so this discrepancy is not surprising. The Cs axial profiles are flatter than predicted by PADLOC, especially in the low-temperature section. 


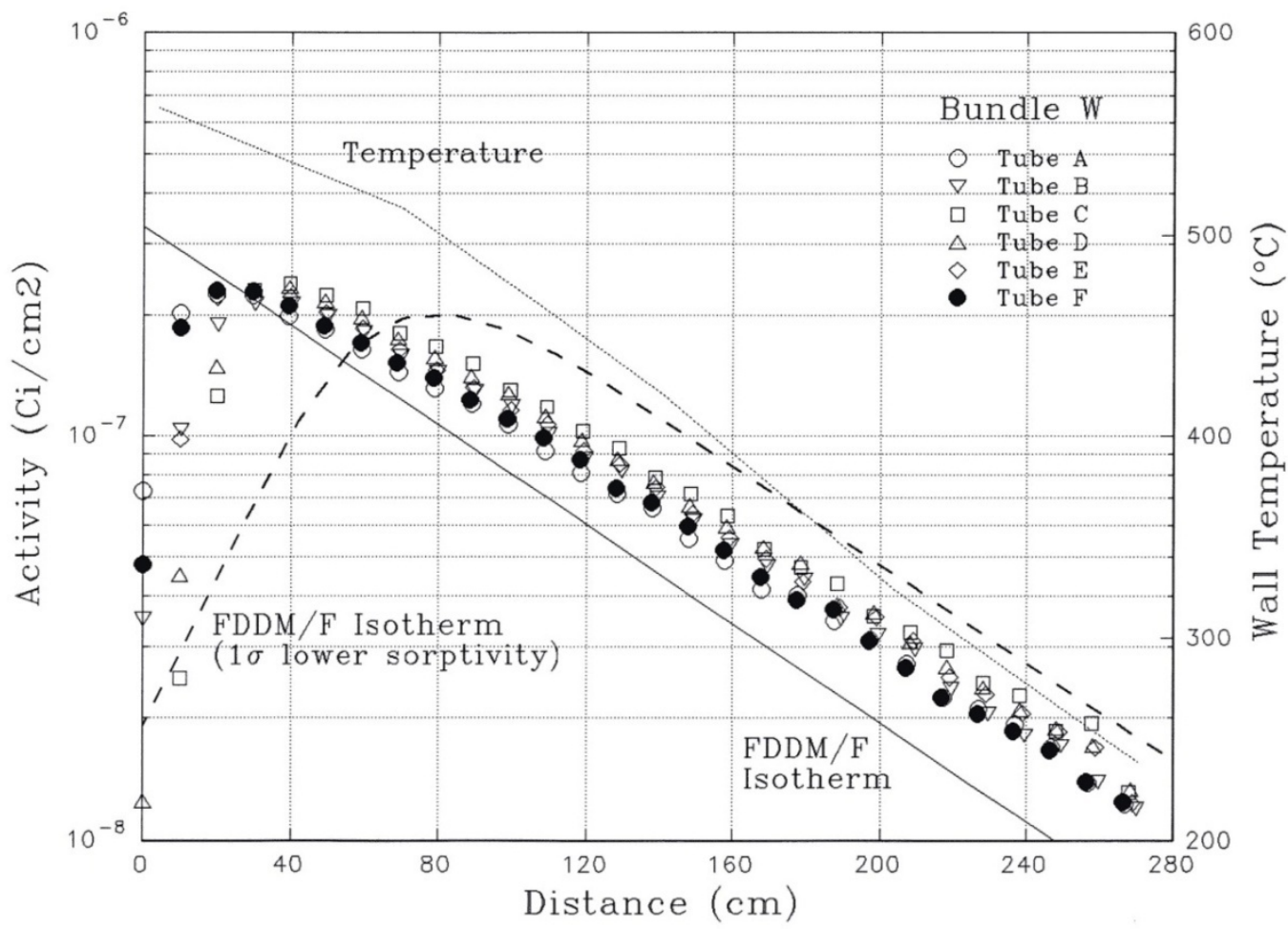

Figure C-4. Predicted and measured Ag-110m plateout profiles in COMEDIE BD-1.

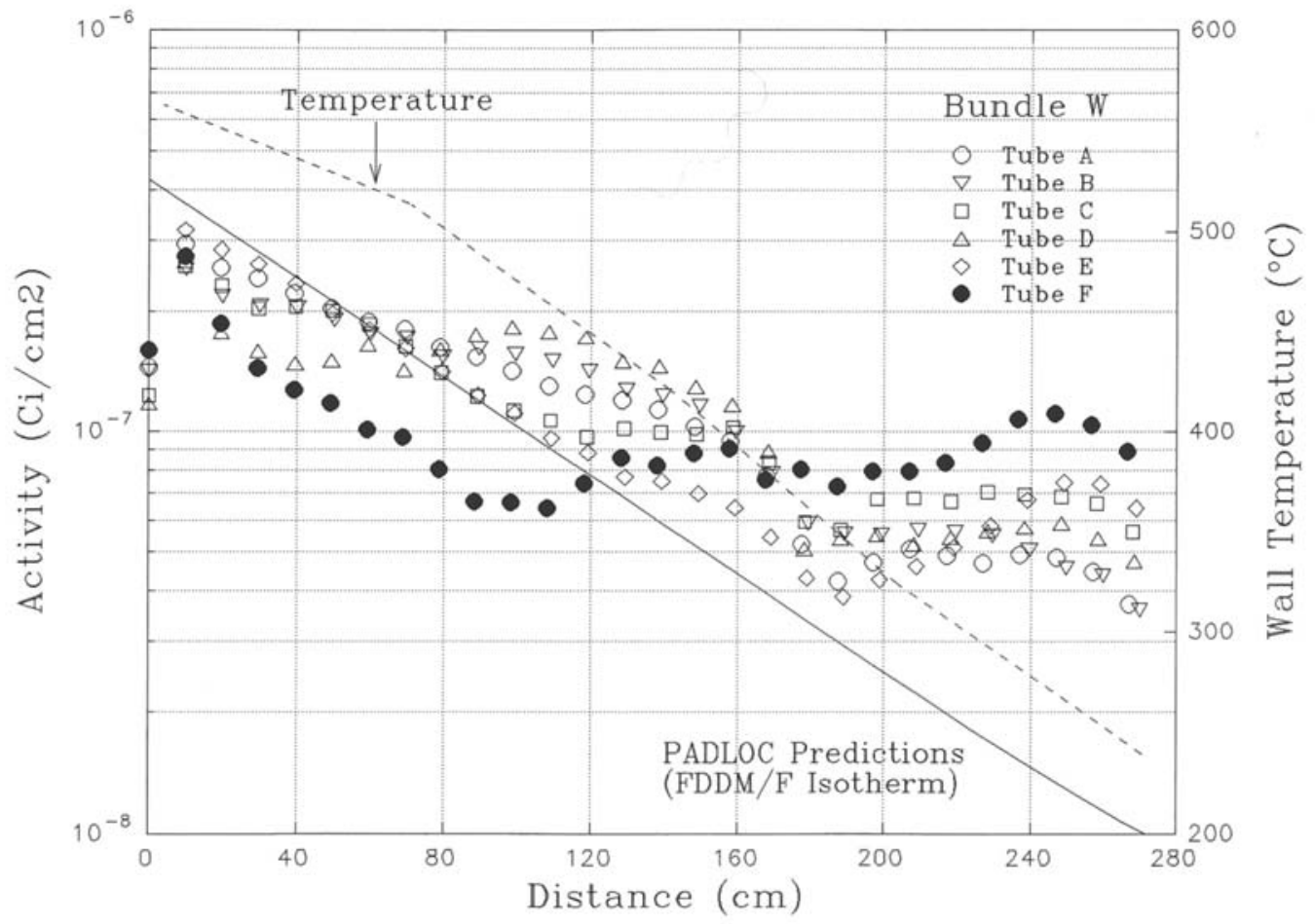

Figure C-5. Predicted and measured Cs-137 plateout profiles in COMEDIE BD-1. 
The extent of additional testing needed to validate the models used to establish plateout rates of condensable fission products (e.g., the need to conduct additional in-pile and out-of-pile fission product transport tests or other less-complex tests to validate the plateout models and codes) is an open issue that is still under discussion by the NGNP Project staff. In addition to other issues, the selection of LBEs, the degree of conservatism in analysis methods required for the various types of LBEs, the allocation of uncertainty in the effectiveness of each of the five barriers to fission product transport, and the extent to which each barrier is counted upon to mitigate fission product transport and release must be taken into account. Resolution of this open issue is expected to occur as the plant design progresses and as agreement is reached regarding the scope of LBEs for the NGNP.

\section{C-6.2 Condensable Fission Product Re-Entrainment}

As introduced previously in this appendix, radionuclides deposited (plated out) in the primary circuit during normal operation can be re-entrained by several mechanisms. If the rate of depressurization as a result of a helium leak is sufficiently rapid, a fraction of the plateout activity can be mechanically re-entrained. This mechanical re-entrainment (commonly referred to as "liftoff") can result from the re-suspension of contaminated particulate matter (e.g., "dust") or from the spallation of friable surface films. A parameter often used to characterize the amount of liftoff is the shear ratio (SR), which is the ratio of the wall shear stress during depressurization to that during normal operation. As an example, the peak shear ratio during a rapid depressurization accident in a modular HTGR is typically $<1.1$ (Stone and Webster 1992).

The current liftoff data base is composed of results from five experiments: (1) the General Atomic InPile Loop (GAIL IV), (2) the General Atomic Deposition Loop Program, (3) the CPL 2 test program, (4) the blowdown tests with Peach Bottom steam generator tube samples, and (5) the four in situ blowdowns of the COMEDIE BD-1 in-pile loop.

Blowdown tests fall into two distinct categories: ex situ and in situ blowdown tests. In ex situ tests, fission products are first plated out on a test specimen, and the specimen is then removed from the test apparatus by destructive means and reinstalled in a blowdown apparatus for blowdown testing. In contrast, for in situ testing, the test specimen is blown down in place without removal from the plateout apparatus.

The liftoff data from the ex situ tests scatter extensively. Moreover, liftoff correlations based upon these ex situ data significantly and consistently over predicted the liftoff fractions observed during the in situ blowdown of the CPL 2/4 loop and during the four in situ blowdowns of the COMEDIE loop (BD-1) at progressively higher shear ratios. This point is illustrated by a comparison of liftoff fractions predicted based upon ex situ data with those measured in the four in situ blowdowns of the COMEDIE loop (BD-1), presented in Table C-1. Consequently, ex situ liftoff data are considered to be unduly conservative and less reliable than the preferred in situ tests.

Deposited radionuclides may also be re-introduced into the coolant by liquid water and/or steam during water ingress events and may also be released to the reactor building if reactor cooling system pressure relief occurs. In principle, both steam and liquid water could cause such removal. There are several potential removal mechanisms. Both steam and liquid water could cause a mechanical removal of contaminated dust or friable surface films. Liquid water could also dissolve and/or leach high-solubility fission products such as cesium. Finally, water vapor may compete with weakly sorbed fission products such as iodine causing "steam-induced vaporization." 
Table C-1. Measured and predicted liftoff in the COMEDIE BD-1 loop test

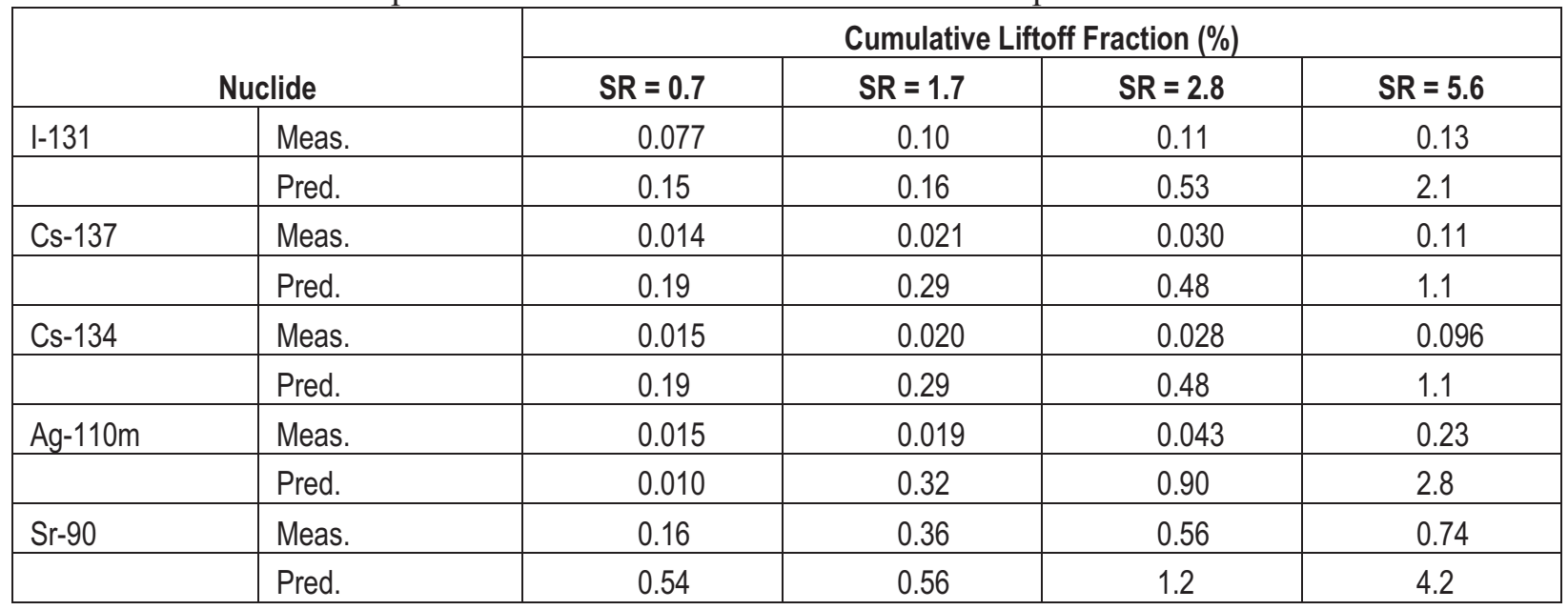

The available data on radionuclide removal by water are limited, and the results tend to scatter extensively; the data have been summarized (IAEA 1997, Martin 1993). There are no comprehensive data to characterize the removal of plateout activity by steam and/or liquid water under prototypical steam-cycle HTGR conditions. Consequently, a constant removal fraction is assumed for steamoff and washoff based upon scoping experiments.

In scoping studies at ORNL, the measured fractional removal of iodine deposited upon T22 tubing ( $2.25 \% \mathrm{Cr}-1 \%$ Mo chromaloy steel) by flowing steam was $60 \%$. This value is assumed in current analysis models to be valid for all radionuclides and under all service conditions. In other scoping studies, the fractional measured removal of cesium deposited upon Alloy 800 and Inconel 617 by liquid water was $50 \%$ (Martin 1993). This value is also assumed in current analysis models to be valid for all radionuclides and under all service conditions.

"Technical Program Plan for the Next Generation Nuclear Plant/Advanced Gas Reactor Fuel Development and Qualification Program" (INL 2008) notes that the POLO code used to predict the liftoff of plated-out fission products during helium coolant leaks needs to be validated to ensure predictive accuracy within $10 \times$ at $95 \%$ confidence. The data must be independent of those used to develop the predictive methods. The present database for validation of radionuclide liftoff is limited and does not explicitly account for the effects of dust. In the single in situ blowdown test of the CPL 2/4 in-pile loop, $<0.5 \%$ liftoff of the deposited activity was observed; however, the maximum SR was only 1.08 .

Moreover, the CPL 2/4 loop contained an inordinate amount of metal-oxide aerosol, so the data are likely to be biased toward high. Considerable additional liftoff data were generated in the COMEDIE BD-1 test, in which four in situ liftoff tests were performed at SRs ranging from 0.7 to 5.6 (see Table C-1). The effects of dust were not included in these tests. Integral test data may be needed for liftoff of key radionuclides from deposits on primary circuit metals during rapid depressurization transients, including the effects of dust.

The presence of circulating and/or deposited particulate matter in the primary circuit may alter the plateout distribution in the circuit during normal operation and the extent to which condensable radionuclides are released from the circuit during depressurization transients. The available data on the effects of dust on radionuclide transport in the primary circuit are largely from reactor surveillance measurements from Peach Bottom, Dragon, and AVR. Samples of deposited particulate matter were obtained from an FSV circulator and have been partially characterized at ORNL. An FSV plateout probe removed at end-of-life was examined at INL, but no particulate matter was detected on the probe filters. 
There are British data on the transport of metal-oxide aerosols in AGRs, but there are no data on the effects of such aerosols on radionuclide transport. There are also German data from measurements made in the AVR; the dust in the AVR resulted primarily from mechanical attrition of the circulating fuel spheres. Limited semi-quantitative data are also available from the General Atomic Deposition Loop Program. In one test, a quantity of graphite powder was added to the out-of-pile loop, and the result was to alter the plateout distribution of Cs137 and Sr90 and increase significantly $(>10 \times)$ the amount of liftoff observed in ex situ blowdown tests. The data needed are measurements under representative conditions that elucidate the effects of dust on the transport of condensable radionuclides in the primary circuit during normal operation and the re-entrainment of these radionuclides during rapid depressurization transients. Sufficient data are needed to ensure that dust effects do not preclude validating design methods to predict fission product transport within the primary circuit to within an accuracy of $10 \times$ at $95 \%$ confidence.

"Technical Program Plan for the Next Generation Nuclear Plant/Advanced Gas Reactor Fuel Development and Qualification Program" (INL 2008) includes tests to measure radionuclide reentrainment (liftoff) from integral tests during rapid depressurization transients in an in-pile loop, if determined to be necessary. The effects of dust should be quantified. Two tests are planned: nominal operation and rapid depressurizaton under "clean" conditions and a repeat of the first test with dust added. These are planned to validate the POLO code by performing pretest predictions and posttest calculations with the codes and comparing the results with the measurements. As noted in Section 5, technology development activities associated with water ingress need to be added to the program.

\section{C-7. RADIONUCLIDE TRANSPORT AND RETENTION IN THE REACTOR BUILDING}

The reactor building is the fifth and final barrier to the transport and release of radionuclides to the environment. Its effectiveness as a release barrier is highly event specific. Typically, a vented low pressure reactor building is the baseline design for both prismatic and pebble bed modular HTGRs.

Retention of radionuclides in the reactor building is influenced by several factors, including the extent to which the design of the building is compartmentalized, by the action of the reactor building heating ventilation, and air-conditioning system, by the action of the building overpressure relief system and any associated filtration, and by reactor building leakage.

In the event of rapid depressurization transients, louvers in the reactor building open, and a significant portion of the released helium coolant is vented to the environment until the pressure in the reactor building is reduced to near atmospheric pressure, at which time the louvers close. Consequently, radionuclide retention in the reactor building is limited for rapid depressurization transients. However, considerable retention is predicted during longer term core conduction cooldown transients during which forced cooling is unavailable [Stone \& Webster Engineering Corp. 1992]. Under such conditions, the natural removal mechanisms occurring in the reactor building, including condensation, fallout, and plateout, are expected to attenuate the release of condensable radionuclides, including radiologically important iodines, by at least an order of magnitude.

Models for the behavior of radionuclides in the reactor building require extensive input, including the transient radionuclide release rates into the building, the physical and chemical forms of these radionuclides, environmental conditions within the reactor building (temperatures, relative humidity, etc.), and correlations (e.g., sorption isotherms, etc.) describing the interactions of the various radionuclides with the exposed surfaces within the reactor building (e.g., metals, painted surfaces, concrete, etc.). 
No direct measurements have been made of radionuclide removal from contaminated helium by condensation, settling, and plateout under the conditions expected in the HTGR reactor building during a core heatup transient. There is an extensive LWR and CANDU database on the behavior of radionuclides in water cooled reactor containment buildings, and major experimental programs are in progress to further characterize the behavior of radionuclides in LWR containment buildings (e.g., the international PHEBUS test program in France). Some of these LWR data, especially those that relate to radionuclide partitioning between steam and liquid phases in steam water mixtures, may be applicable to radionuclide behavior in the HTGR reactor building. Consequently, the extensive literature on radionuclide transport in water reactor containment buildings was reviewed, and an assessment was made as to the utility of this database to support analysis of radionuclide transport in the HTGR reactor building.

The transport behavior of radionuclides during core heatup accidents in HTGRs is much simpler than that in LWRs. Relatively few radionuclides (primarily, radioisotopes of $\mathrm{Kr}, \mathrm{Xe}, \mathrm{I}, \mathrm{Te}, \mathrm{Ag}, \mathrm{Cs}$ and $\mathrm{Sr}$ ) are released from the core. No heavy metals or core structural materials are released, and the radionuclide mass concentrations are so low that aerosols are not expected to form. Dust present in the primary circuit during normal operation and liftoff of plateout may add to the activity released from the primary circuit into the reactor building during rapid depressurization accidents, but the chemical and physical nature of this material is quite different from an LWR corium aerosol. Consequently, the water reactor aerosol transport data appear to be of little direct relevance to behavior of radionuclides released from a gas-cooled reactor into the reactor building. However, the aerosol transport codes might be adaptable for analyzing depressurization transients in HTGRs, provided the requisite material property data were available. Some of the water reactor data on iodine behavior in steam-liquid water systems might be applicable to steam cycle HTGRs. Overall, however, based on a review and assessment of the data, the extensive, experimental water-cooled reactor database for radionuclide transport in LWR containment buildings appears to be of limited value for refining and independently validating the design methods used to predict radionuclide transport in the HTGR reactor building.

The component models currently used to predict convective mass transfer in the reactor building are the same as those used for predicting mass transfer in the core and primary circuit, although the environmental conditions are different. The models used to predict radionuclide sorption on the structural materials in the reactor building have the same functional forms as those used to predict sorption in the primary circuit, although the environmental conditions again are different (e.g., lower temperatures). In addition to these common models, simple component models are used to predict aerosol transport in the reactor building.

As cited in [INL 2008], as the design of the HTGR progresses, new technology development activities may need to be defined for characterizing radionuclide transport in the reactor building for the accident scenarios expected to be postulated for the NGNP. A test plan defining an experimental program to provide the needed data will be developed and executed. 


\section{Appendix D}

\section{Prismatic Code Descriptions (General Atomics)}




\section{Appendix D Prismatic Code Descriptions (General Atomics)}

Table D-1 summarizes the codes used by General Atomics to calculate radionuclide source terms for prismatic fuel high temperature gas-cooled reactors (HTGRs). Analogous codes for use in source term calculations for prismatic core designs are in various stages of development at AREVA.

The principal codes from Table D-1 that were developed at General Atomics to predict fuel performance and fission product transport include PISA, CAPPER, TRAMP, SURVEY, TRAFIC-FD, PADLOC, POLO, and SORS. PISA was developed to calculate pressure vessel failure probabilities. CAPPER and TRAMP are used to calculate fuel performance and fission product release from the fuel for irradiation test capsules, and SURVEY and TRAFIC-FD perform the same calculations for entire HTGR cores. PADLOC calculates the distribution of condensable fission products in the primary circuit, and POLO calculates the re-entrainment (liftoff) of the condensable fission products during depressurization events. SORS is used to calculate fission product release during accident conditions. Brief discussions of these principal codes follow Table D-1.

Table D-1. General Atomics codes for predicting radionuclide source terms for prismatic HTGRs.

\begin{tabular}{|c|c|c|c|}
\hline Function & $\begin{array}{c}\text { General } \\
\text { Atomics Codes }\end{array}$ & $\begin{array}{l}\text { Key Component Models/ } \\
\text { Input Data }\end{array}$ & Prerequisites \\
\hline $\begin{array}{l}\text { Calculate radionuclide inventories in } \\
\text { reactor core } \\
\text {-Fission products } \\
\text {-Transmutation products } \\
\text {-Neutron activation products } \\
\text { (including activation of impurities in } \\
\text { core materials) } \\
\text { Used for zero-dimensional fuel-cycle } \\
\text { depletion, burnable poison loading } \\
\text { analysis, and to compute long-term } \\
\text { nuclide decay heat rates }\end{array}$ & $\begin{array}{l}\text { GARGOYLE } \\
\text { ORIGEN-2 } \\
\text { (ORNL) }\end{array}$ & $\begin{array}{l}\text { Heavy metal and graphite } \\
\text { inventories } \\
\text { Impurities in core components } \\
\text { Core thermal power } \\
\text { Microscopic cross sections } \\
\text { Self-shielding nuclide } \\
\text { coefficients } \\
\text { Core and region volumes } \\
\text { Buckling }\end{array}$ & $\begin{array}{l}\text { Fuel cycle characteristics } \\
\text { Fuel and graphite product } \\
\text { specifications } \\
\text { Cross section libraries (e.g., ENDFB-6) } \\
\text { Multi-group energy structure } \\
\text { Nuclide depletion scheme } \\
\text { (GARGOYLE) } \\
\text { Fission product yields (GARGOYLE) }\end{array}$ \\
\hline $\begin{array}{l}\text { Calculate overall plant mass } \\
\text { balance for radionuclides } \\
\text {-Total core/spent fuel elements } \\
\text {-Total circulating activities } \\
\text {-Total plateout inventories } \\
\text {-Purification system inventories } \\
\text { Used to generate radionuclide } \\
\text { design criteria }\end{array}$ & $\begin{array}{l}\text { RADC } \\
\text { RANDI }\end{array}$ & $\begin{array}{l}\text { Isotope nuclear properties (e.g., } \\
\text { fission yields, decay constants, } \\
\text { decay chains, etc.) } \\
\text { He mass-flow rate } \\
\text { Total circulating He inventory } \\
\text { He purification rate }\end{array}$ & $\begin{array}{l}\text { Basic plant design parameters (e.g., } \\
\text { power level, plant lifetime, capacity } \\
\text { factor, etc.) } \\
\text { Basic core design parameters (e.g., } \\
\text { number of fuel elements, fuel } \\
\text { residence time, etc.,) }\end{array}$ \\
\hline \multirow[t]{2}{*}{$\begin{array}{l}\text { Calculate thermal and stress } \\
\text { histories for TRISO-coated fuel } \\
\text { particles } \\
\text { Used to specify particle attributes } \\
\text { (e.g., kernel diameter, coating } \\
\text { thicknesses, etc.) for fuel particles }\end{array}$} & \multirow[t]{2}{*}{$\begin{array}{l}\text { PISA } \\
\text { SOLGASMIX-PV }\end{array}$} & $\begin{array}{l}\text { Material properties of } \\
\text { pyrocarbon and SiC coatings as } \\
\text { function of temperature and fast } \\
\text { fluence } \\
\text { Thermal properties of } \\
\text { pyrocarbon and SiC coatings }\end{array}$ & $\begin{array}{l}\text { Core operating envelope (burnup, fast } \\
\text { fluence, temperature) } \\
\text { As manufactured fuel attributes } \\
\text { (e.g., allowable standard deviations in } \\
\text { kernel and coating dimensions, } \\
\text { allowable coating defects, etc.) }\end{array}$ \\
\hline & & $\begin{array}{l}\text { Total yields of fission gases as } \\
\text { function of burnup. }\end{array}$ & $\begin{array}{l}\text { Allowable failure during normal } \\
\text { operation and accidents }\end{array}$ \\
\hline
\end{tabular}


Table D-1. (continued).

\begin{tabular}{|c|c|c|c|}
\hline Function & $\begin{array}{c}\text { General } \\
\text { Atomics Codes }\end{array}$ & $\begin{array}{l}\text { Key Component Models/ } \\
\text { Input Data }\end{array}$ & Prerequisites \\
\hline $\begin{array}{l}\text { Calculate 3-D fuel performance } \\
\text { analysis for normal operation } \\
\text {-Fuel failure } \\
\text {-Fission gas release } \\
\text { To determine whether core design } \\
\text { meets radionuclide design criteria }\end{array}$ & SURVEY & $\begin{array}{l}\text { Fuel particle design } \\
\text { As manufactured fuel attributes } \\
\text { Fuel particle performance } \\
\text { models } \\
\text { Fission gas release models }\end{array}$ & $\begin{array}{l}\text { 3-D power distributions } \\
\text { (DIF3D/SORT3D output) } \\
\text { Core operating envelope } \\
\text { Flow distribution } \\
\text { Radionuclide design criteria to define } \\
\text { allowable core releases } \\
\end{array}$ \\
\hline $\begin{array}{l}\text { Calculate 3-D fission metal release } \\
\text { for normal operation } \\
\text {-Release from kernels } \\
\text {-Release from particles } \\
\text {-Release from fuel element } \\
\text { To determine whether core design } \\
\text { meets radionuclide design criteria }\end{array}$ & $\begin{array}{l}\text { COPAR-FD } \\
\text { TRAFIC-FD }\end{array}$ & $\begin{array}{l}\text { Fuel particle design } \\
\text { As manufactured fuel attributes } \\
\text { Diffusion coefficients (kernels, } \\
\text { coatings, graphite) } \\
\text { Sorption isotherms for matrix } \\
\text { and graphite }\end{array}$ & $\begin{array}{l}\text { 3-D power, burnup and fluence } \\
\text { distributions (DIF3/SORT3D output) } \\
\text { Fuel failure distributions (SURVEY } \\
\text { output) } \\
\text { Radionuclide design criteria to define } \\
\text { allowable core releases }\end{array}$ \\
\hline $\begin{array}{l}\text { Calculate plateout distributions in } \\
\text { primary circuit } \\
\text { To provide source terms for: } \\
\text {-Calculating operations and } \\
\text { maintenance dose rates } \\
\text {-Shielding \& cask design } \\
\text {-Depressurization accidents } \\
\text { ("liftoff") }\end{array}$ & PADLOC & $\begin{array}{l}\text { Convective mass transfer } \\
\text { correlations [Sh = Sh(Re, Sc)] } \\
\text { Sorption isotherms for graphite } \\
\text { and primary circuit metals }\end{array}$ & $\begin{array}{l}\text { Primary circuit conceptual design (e.g., } \\
\text { geometry, materials of construction, } \\
\text { etc.) } \\
\text { Primary circuit operating conditions } \\
\text { (pressure, temperature, flow rate) } \\
\text { Radionuclide design criteria to provide } \\
\text { total plateout inventories }\end{array}$ \\
\hline $\begin{array}{l}\text { Calculate production rates and } \\
\text { overall plant mass balance for } \\
\text { tritium } \\
\text {-Fuel elements } \\
\text {-Reflector elements } \\
\text {-Total circulating inventory } \\
\text {-Permeation through heat } \\
\text { exchanger to contaminate } \\
\text { secondary coolants } \\
\text { Used to generate } \mathrm{H}-3 \text { source terms }\end{array}$ & TRITGO & $\begin{array}{l}\text { He-3/He-total in primary He } \\
\text { Li impurities in core materials } \\
\text { (from product specifications) } \\
\text { Sorption isotherms for matrix } \\
\text { and core graphites } \\
\text { Permeation coefficient } \\
\text { correlations for primary circuit } \\
\text { metals }\end{array}$ & $\begin{array}{l}\text { Reactor and primary system } \\
\text { conceptual design (e.g., geometry, } \\
\text { materials of construction, etc.) } \\
\text { Reactor and primary system operating } \\
\text { conditions (pressure, temperature, flow } \\
\text { rate) } \\
\text { Plant helium coolant chemistry } \\
\text { specification (i.e., allowable coolant } \\
\text { impurities, especially } \mathrm{H}_{2} \mathrm{O} \text { and } \mathrm{H}_{2} \text { ) } \\
\text { He purification system flow rate and } \\
\text { efficiency for } \mathrm{H}-3 \text { removal }\end{array}$ \\
\hline $\begin{array}{l}\text { Calculate production rates and } \\
\text { overall plant mass balance for } \\
\text { Carbon-14 } \\
\text {-Fuel elements } \\
\text {-Reflector elements } \\
\text { Generate C-14 source terms: } \\
\text {-Disposal of spent fuel elements } \\
\text {-Disposal of spent reflector } \\
\text { elements }\end{array}$ & $\begin{array}{l}\text { GARGOYLE } \\
\text { None (hand } \\
\text { calculations) }\end{array}$ & $\begin{array}{l}\mathrm{N}-14 \text { impurities in core } \\
\text { materials (from product } \\
\text { specifications) } \\
\text { Nuclear properties (e.g., cross } \\
\text { sections) }\end{array}$ & $\begin{array}{l}\text { Reactor system conceptual design } \\
\text { (e.g., geometry, materials of } \\
\text { construction, etc.) } \\
\text { Thermal flux distributions in reactor } \\
\text { core }\end{array}$ \\
\hline
\end{tabular}


Table D-1. (continued).

\begin{tabular}{|c|c|c|c|}
\hline Function & $\begin{array}{c}\text { General } \\
\text { Atomics Codes }\end{array}$ & $\begin{array}{l}\text { Key Component Models/ } \\
\text { Input Data }\end{array}$ & Prerequisites \\
\hline $\begin{array}{l}\text { Calculate 3-D fuel performance and } \\
\text { fission product release for core } \\
\text { heatup accidents } \\
\text {-Incremental fuel failure } \\
\text {-Fission gas release } \\
\text {-Fission metal release } \\
\text { To determine whether design meets } \\
\text { accident dose limits }\end{array}$ & SORS/NP1 & \begin{tabular}{|l|} 
Fuel particle design \\
As manufactured fuel attributes \\
Fuel performance models for \\
accident conditions \\
Diffusion coefficients (kernels, \\
coatings, graphite) \\
Sorption isotherms for matrix \\
and graphite \\
\end{tabular} & $\begin{array}{l}\text { Definition of design basis accidents } \\
\text { (DBAs) and Beyond Design Basis } \\
\text { Accidents (BDBAs) } \\
\text { Initial conditions from core analyses for } \\
\text { normal operation (e.g., power } \\
\text { distributions, etc.) } \\
\text { 3-D, transient thermal/hydraulic } \\
\text { performance of core during accident }\end{array}$ \\
\hline $\begin{array}{l}\text { Calculate 3-D fuel performance } \\
\text { analysis for water ingress accidents } \\
\text {-Incremental fuel failure } \\
\text {-Fission gas release (especially I } \\
\text { isotopes) } \\
\text {-Fission-metal release } \\
\text {-Core corrosion } \\
\text { To determine whether core design } \\
\text { meets accident dose limits }\end{array}$ & OXIDE-4 & \begin{tabular}{|l|} 
Fuel particle design \\
As-manufactured fuel attributes \\
Reaction kinetics for $\mathrm{H}_{2} \mathrm{O}$ and \\
core materials \\
Fuel performance models for \\
$\mathrm{H}_{2} \mathrm{O}$ ingress conditions \\
Diffusion coefficients (kernels, \\
coatings, graphite) \\
Sorption isotherms for matrix \\
and graphite \\
\end{tabular} & $\begin{array}{l}\text { Definition of DBAs and BDBAs } \\
\text { Initial conditions from core analyses for } \\
\text { normal operation (e.g., power } \\
\text { distributions, fuel failure distributions, } \\
\text { etc.) } \\
\text { Transient } \mathrm{H}_{2} \mathrm{O} \text { ingress rates } \\
\text { 3-D, transient thermal/hydraulic } \\
\text { performance of core during accident } \\
\text { Definition of allowable core release } \\
\text { rates during core heatup accidents } \\
\text { (derived from allowable offsite doses). }\end{array}$ \\
\hline $\begin{array}{l}\text { Radionuclide retention in reactor } \\
\text { building } \\
\text { Calculate fractional re-entrainment } \\
\text { ("liftoff") of plateout activity in } \\
\text { primary circuit during } \\
\text { depressurization accidents } \\
\text {-Source term for offsite dose } \\
\text {-Contamination of reactor building } \\
\text { To determine whether plant design } \\
\text { meets accident dose limits }\end{array}$ & POLO & $\begin{array}{l}\text { Liftoff correlations (fractional re- } \\
\text { entrainment as function of shear } \\
\text { ratioj) }\end{array}$ & $\begin{array}{l}\text { Definition of DBAs and BDBAs } \\
\text { Primary circuit conceptual design (e.g., } \\
\text { geometry, materials of construction, } \\
\text { etc.) } \\
\text { Primary circuit operating conditions } \\
\text { during depressurization transient (to } \\
\text { calculate shear ratios) } \\
\text { Initial plateout distributions (end-of-life } \\
\text { plateout inventories assumed) }\end{array}$ \\
\hline $\begin{array}{l}\text { Calculate radionuclide transport } \\
\text { from reactor to site boundary during } \\
\text { DBAs and BDBAs } \\
\text {-Radionuclide transport in } \\
\text { atmosphere (plume dispersion) } \\
\text {-On-site attenuation (e.g., fallout, } \\
\text { washout) } \\
\text { To determine whether plant design } \\
\text { meets site boundary dose limits } \\
\text { To determine whether plant design } \\
\text { meets risk goals. }\end{array}$ & $\begin{array}{l}\text { MACCS } \\
\text { (SNL) }\end{array}$ & $\begin{array}{l}\text { Physical and chemical forms of } \\
\text { radionuclides released from } \\
\text { primary circuit (e.g., aerosols, I } \\
\text { speciation, etc.) } \\
\text { Radionuclide attenuation } \\
\text { models (e.g., settling, } \\
\text { deposition, condensation, etc.) }\end{array}$ & $\begin{array}{l}\text { Definition of DBAs and BDBAs } \\
\text { Transient radionuclide release rates } \\
\text { from primary circuit to reactor building } \\
\text { (e.g., SORS/NP1 or OXIDE4 output) } \\
\text { Environmental conditions in reactor } \\
\text { building } \\
\text { Plant site characteristics (e.g., physical } \\
\text { dimensions, meteorology, } \\
\text { demographics, etc.) } \\
\text { Definition of allowable offsite doses for } \\
\text { DBAs and BDBAs. }\end{array}$ \\
\hline
\end{tabular}

j. Shear ratio is the ratio of the wall shear stress during a depressurization transient to the wall shear stress during normal $100 \%$ power operation. 


\section{D-1. PISA}

Fission gases are generated within the kernel of the fuel particle with burnup and accumulate in the porous low-density buffer layer. The resulting internal fission gas pressure can be as high as several hundred atmospheres, which leads to tensile stresses in the coating layers. PISA is a 1-D (one dimensional) finite element computer code that performs thermal-stress history calculations for coated particles under irradiation conditions and calculates failure probabilities using a two- parameter Weibull model. The PISA code has built in functions that calculate the fission gas pressure as a function of burnup, temperature, fuel enrichment, and other parameters. PISA can also perform calculations with the assumption that one or more layers have failed, with failure defined as the loss of load-carrying capability in the tangential direction while retaining the radial stiffness of the material.

PISA calculates the stress distribution in the coating layers by numerically solving coupled thermal-stress equations using a 1-D finite element method. Three material models are considered in PISA to model material properties: linear elastic, linear viscoelastic materials with stationary creep, and linear viscoelastic materials with stationary and transient creep. The first material model is for rigid and dimensionally stable $\mathrm{SiC}$ and the other two are for $\mathrm{PyC}$, which shrinks and creeps in preferred orientation directions (tangential and radial) during irradiation. Mechanical failure of a fuel particle coating layer is defined as the stress loading on the coating layer exceeding the material strength of the coating.

\section{D-2. CAPPER And SURVEY}

The CAPPER code was developed at General Atomics to predict fuel performance and fission gas release ( $\mathrm{Kr}, \mathrm{Xe}$ and I isotopes), which is expressed as a release rate-to-birth rate ratio $(\mathrm{R} / \mathrm{B})$, for irradiation test capsules and fuel performance (but not fission product release) in out-of-pile heating tests of irradiated test fuel using the fuel failure and fission gas release models given in General Atomics' internal design manuals. SURVEY uses the same models to calculate fuel performance and fission gas release during normal reactor operation for an entire HTGR core.

Inputs to CAPPER and SURVEY include the fraction of particles having four types of asmanufactured defects (missing or defective buffer, IPyC, SiC, or OPyC layers), all of which are included in the fuel performance models used in these codes. The fission product release behavior in TRISO particles depends on the condition of $\mathrm{SiC}$ and OPyC layers, and, to a lesser extent, the condition of the IPyC layer. Each of these layers can be either intact or failed. Thus there are multiple coating condition categories (one of which is all three layers intact), each of which has different fission product release characteristics. CAPPER and SURVEY calculate the fraction of the fuel particle population in each of these categories. Table D-2 describes the fission product release characteristics of the four most important fuel particle condition categories.

Table D-2. Definition of coated particle failure categories.

\begin{tabular}{|c|c|c|c|c|}
\hline \multirow[b]{2}{*}{ Category } & \multirow[b]{2}{*}{$\mathrm{SiC}$} & \multirow[b]{2}{*}{ OPyC } & \multicolumn{2}{|c|}{ Fission product Release Characteristics } \\
\hline & & & Gases & Metals \\
\hline 1 & Intact & Intact & No Release & $\begin{array}{l}\text { Some } \mathrm{Ag} \text { diffusive release at high- temperature } \\
\text { accident conditions. }\end{array}$ \\
\hline 2 & Intact & Failed & No Release & $\begin{array}{l}\text { Some } \mathrm{Ag} \text { diffusive release at high- temperature } \\
\text { accident conditions. }\end{array}$ \\
\hline 3 & Failed & Intact & $\begin{array}{l}\text { Some diffusive release at high } \\
\text { temperature accident conditions }\end{array}$ & $\begin{array}{l}\text { No resistance to release from PyC layers. The } \\
\text { fuel kernel provides some resistance to release }\end{array}$ \\
\hline 4 & Failed & Failed & $\begin{array}{l}\text { No resistance to release by coating } \\
\text { layers. Only the fuel kernel provides } \\
\text { resistance to release }\end{array}$ & $\begin{array}{l}\text { No resistance to release by coating layers. Only } \\
\text { the fuel kernel provides resistance to release. }\end{array}$ \\
\hline
\end{tabular}




\section{D-3. TRAFIC-FD And TRAMP}

The TRAFIC-FD code is used to calculate fission product transport in HTGR cores. The geometry modeled in the code includes the fuel compacts, the graphite webs, and the coolant holes in a typical HTGR fuel block. The transport of fission products can be described with diffusion equations, and the finite difference method is utilized in the TRAFIC-FD code to solve these equations. The SURVEY code is used to obtain the detailed history of the core environment necessary for the calculation. The release of fission products for the entire core is found by sampling calculation cells at several locations in each fuel block and at every block throughout the reactor core. The basic geometry dealt with in TRAFIC-FD is the smallest unit of symmetry in a fuel block, a 30-60-90 triangle with fuel compact, web graphite, and coolant hole. A 1-D approximation is made in the analysis.

There are four parts to the transport model in TRAFIC-FD. First, the radionuclide releases from the fuel microspheres are calculated; the radionuclides released from the microspheres are assumed to be available instantly at the outside surface of the cylindrical fuel compact. A gap transport model between the outside surface of the fuel compact and the graphite web surface is the second part of the model. The third part of the model is diffusion through the graphite; the fourth part of the calculation covers the transport across the coolant-hole boundary layer.

The TRAMP code performs similar calculations for irradiation test capsule geometries.

\section{D-4. PADLOC}

The PADLOC code was developed to calculate the distribution ("plateout distribution") of condensable fission products on surfaces within the primary circuit. The plateout distributions are derived by solving mass-balance equations for a gas contaminated with radionuclides flowing through a conduit with various boundary and interface conditions relating the concentration of the radionuclide in the coolant to its concentration on the fixed surfaces. The key material property correlations used in calculating the deposition of condensable fission products in the primary circuit are convective mass transfer correlations and the sorption isotherms for fission products of interest over primary circuit materials. These isotherms predict the equilibrium surface loading as a function of partial pressure and surface temperature.

The available data indicate the structural materials in the primary circuit are essentially "perfect sinks" for all condensable radionuclides except for iodine, cesium, and, at the higher surface temperatures, silver and antimony. The iodine isotopes, in particular, deposit preferentially in the colder locations in the primary circuit.

\section{D-5. POLO}

Simple empirical models are used to correlate measured liftoff fractions with gas dynamic parameters (e.g., IAEA 1997). General Atomics has traditionally employed an empirical shear ratio (SR) model for correlating liftoff data. For fully turbulent flow in a circular duct, it can be easily shown that the shear ratio, or the ratio of the wall shear stress during blowdown to the steady-state wall shear stress, is a simple function of pressure, velocity, and temperature.

General Atomics has developed the POLO code to calculate the integral fission product liftoff in the primary circuit during a depressurization transient. POLO contains an empirical correlation which gives the fractional liftoff as a function of SR. The initial plateout distribution is obtained from the PADLOC code, and the SR distribution in the primary circuit as a function of time and space is obtained from a transient thermal/fluid dynamics code. POLO then integrates the transient SR distribution over the initial 
plateout distribution to predict the cumulative release from the primary circuit. POLO also contains a simple washoff model for the analysis of wet depressurization transients.

POLO also contains radionuclide attenuation models (gravitational settling, deposition, condensation, etc.) that are used to calculate the behavior of radionuclides in the reactor building and out to the environment during and following depressurization transients.

Efforts are underway at Sandia National Laboratory to adapt the light water reactor MELCOR code package for use in the analysis of radionuclide behavior in the reactor building during and following depressurization events.

\section{D-6. SORS}

The SORS code was developed to calculate the release of fission products, transuranics, and other radionuclides from the reactor fuel to the coolant for postulated core heat-up scenarios in an HTGR core. SORS calculates the fractional release of fission products from the fuel particles based on diffusion in a 1-D spherical geometry using data and formulations from General Atomics' Fuel Design Data Manual. In calculating the fractional release of fission products from the fuel, SORS considers the (1) presence of various types of defects in the fuel particles at the onset of the accident, (2) failure of one or more of the fuel particle coating layers by a number of mechanisms during the accident, (3) the heavy metal contamination fraction, (4) diffusion of volatile and metallic fission products through the fuel kernel, (5) diffusion of metallic fission products through intact $\mathrm{SiC}$ coatings, and (6) diffusion of volatile fission products through intact OPyC coatings. The calculations account for the influence of burnup, fast neutron fluence, irradiation and accident condition temperatures, and radionuclide concentrations.

The fuel particle defect fractions at the onset of an accident (or heating phase) are provided as input to SORS based on the fuel performance calculated using the CAPPER or SURVEY codes. SORS also considers fission product release from heavy-metal contamination.

The accident scenario parameters provided as input data to SORS include the time-averaged temperature during the irradiation phase preceding the accident, the burnup and fast-neutron fluence at the onset of the accident, and the time-dependent temperature during the accident. SORS calculates the SiC failure probability during the accident as a function of time, temperature, burnup, and fast fluence, and uses the values along with the initial failure probabilities and particle defect fractions input to the code to calculate the fraction of failed fuel particles in the four categories identified in Table D-2.

Because there is essentially no thermal gradient during accidents, particle failure by kernel migration does not occur. There also is no particle failure by corrosion of the $\mathrm{SiC}$ by fission products because of the relatively short reaction times involved during accident scenarios. The dominant failure mechanism for $\mathrm{SiC}$ failure during accident conditions is $\mathrm{SiC}$ thermal decomposition.

The fuel particle failure fractions calculated in SORS provide the source terms for fission product release from the particles, which is calculated using the fission product release models that are summarized in Section 4.4 and Appendix C of this white paper. These include models for diffusion of gaseous and metallic fission products from the kernel in failed fuel particles, diffusion of gaseous and metallic fission products through intact OPyC coating layers in particles having a defective SiC layer, and diffusion of metallic fission products through the $\mathrm{SiC}$ in intact fuel particles. 


\section{Appendix E}

\section{Description of PBMR Codes (PBMR (Pty) Ltd.)}




\section{Appendix E Description of PBMR Codes (PBMR (Pty) Ltd.)}

This appendix provides information on the approach to calculating fission product generation, transport, and release for pebble bed high temperature gas-cooled reactors (HTGRs). The methods used for these analyses are continuously evolving. Additional information can be found in (Rollig 1977; van der Merwe and Venter 2009; van der Merwe and Clifford 2008; and van der Merwe 2009)

Fission product release analysis at pebble bed modular reactor (PBMR) is divided into relatively short-lived gaseous and long-lived metallic fission products. Fission product release analyses are summarized in Figure E-1. The reactor design is analyzed by the core neutronics codes - VSOP for normal operation and TINTE for accident conditions - and by the CFD thermal hydraulics code. These codes supply the necessary input parameters (temperatures, neutron fluxes, power densities, residence times, etc.) for the fission product release codes NOBLEG (gases) and FIPREX/GETTER (metals) to calculate the fission product releases from the pebble bed core. NOBLEG and FIPREX/GETTER are codes used to analyze fission product transport from the fuel into the helium coolant. NOBLEG determines gaseous fission product releases during normal operation, while FIPREX/GETTER calculates normal operation and transient diffusion behavior for metallic fission products.

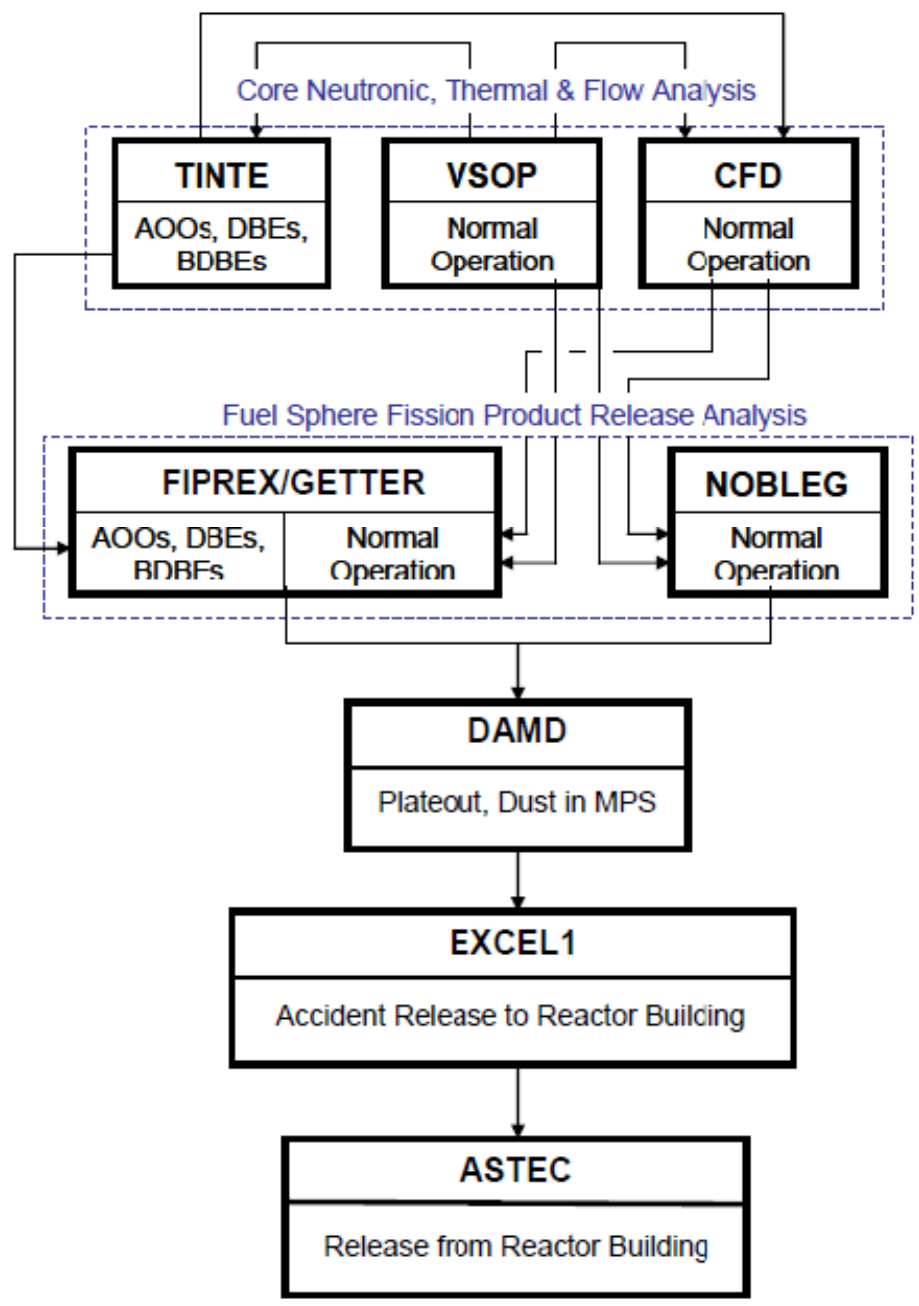

Figure E-1. PBMR fission product release analyses. 
These fission product release values are used by the dust and plateout simulation code DAMD to calculate the fission product concentration in the main power system (MPS). These fission product concentrations are then used to determine the radiological doses that operational personnel might experience during maintenance work at the PBMR. The fission products released from the MPS into the reactor building during accidental leaking or pipe breaks are modeled by EXCEL1. The behavior of fission products in the reactor building and their final release into the environment is modeled by ASTEC and other software that incorporate reactor building design and meteorological parameters.

Summary descriptions of each of these codes are provided in this appendix.

\section{E-1. VSOP, TINTE, and CFD}

VSOP (Very Special Old Programs) is used to determine the neutronic behavior of the reactor during normal operation. VSOP provides input to CFD (Computational Fluid Dynamics) for thermal hydraulic analyses during normal operation and input to NOBLEG and FIPREX/GETTER for the fission gas and metallic fission product release analyses during normal operation.

VSOP also provides input (fuel element burnup history and spatial isotopic distributions) to TINTE (Time Dependent Neutronics and Temperatures), which determines the time-dependent behavior of the reactor during transient events. Using the pressure and flow rates provided by flow analysis codes such as CFD, TINTE calculates the core response and provides the fuel temperatures as well as neutron fluxes to FIPREX/GETTER for the metallic radionuclide release calculations for transient events. TINTE also has the ability to model corrosion due to air ingress. TINTE is mainly used to model transients in HTGRs. These events can be slow (depressurized loss of forced cooling [DLOFC] over 24 hours, xenon oscillations over a few days), or fast (control rod ejection). The code provides transient temperature data for core component design and design limits (fuel, reflectors, control rods, etc), as well as fission and total power indicators.

\section{E-2. NOBLEG}

The activity of gaseous fission product release is calculated with the code NOBLEG. In NOBLEG, the main sources contributing to gaseous fission product release are the heavy-metal contamination in the fuel graphite and defective/failed coated particles. Standard particles within the specification limits are not expected to contribute to the release of gaseous fission products under normal operating conditions. NOBLEG is a steady-state fission product release code using Booth equations to solve short-lived gaseous fission product diffusion behavior under normal operating conditions. The Booth equations solve Fick's Law diffusion in spherical geometry using effective diffusion coefficients. NOBLEG contains thermal hydraulic and mass-transfer subroutines to calculate the temperature distribution in fuel elements to determine diffusion rates in each fuel component according to relations dependent on fast neutron fluence and helium temperatures. NOBLEG calculates all radiologically important short-lived gaseous fission products (including bromine and iodine, which are based on krypton and xenon measured parameters, respectively). Gaseous fission product releases under normal operating conditions as well as low vapor pressure water ingress incidents are calculated. NOBLEG calculates the R/B values from contamination and failed coated particles separately and estimates the expected fission product release from the core and the resulting helium coolant activities.

NOBLEG is a legacy code from the German High Temperature Reactor (HTR) program developed by Hochtemperatur Reaktorbau (HRB), bought and further developed by PBMR for PBMR-specific parameters and conditions. The code is versatile and can be easily applied to any other high temperature pebble bed-type reactor designs. The NOBLEG calculation model has been extensively verified and validated with German irradiation test data. 


\section{E-3. FIPREX/GETTER}

The transient release behavior of long-lived metallic fission products can be predicted by using diffusion models. The most important input data for coated-particle performance during normal operation will be the fraction of failed/defective particles and the fraction of heavy-metal contamination in the fuel element graphite in combination with the transport data of coated-particle materials and fuel element graphite. Fission product transport through the material layers is dependent on two basic theoretical models: first, the transport process that describes the movement of fission products, and second, the thermofluid model that determines material temperatures that influence the rate of the first process. Both models are incorporated into the computer code FIPREX/GETTER. In addition to diffusion, other release mechanisms during normal operation are the recoil effect and the knockout effect. Both present a geometrical problem and are not dependent on temperature, making them significantly more important at lower temperatures. FIPREX/GETTER, based on Fick's Laws of Diffusion, was developed to model experimental (irradiation tests) and operational (normal and accident) conditions. The code solves the differential equations of Fick's Laws with numerical techniques. FIPREX/GETTER includes subroutines that calculate the burn-up and the power history of a fuel sphere in the core and the temperature distribution in the spheres on the basis of given thermal and fast neutron fluxes and helium coolant temperatures. The FIPREX part of FIPREX/GETTER is a wrapper program to automate GETTER and TINTE Monte Carlo accident condition calculations (i.e., GETTER is executed inside FIPREX operation). FIPREX was further developed to perform all GETTER core calculations, originally for Depressurized Loss of Forced Cooling (DLOFC) as well as Pressurized Loss of Forced Cooling (PLOFC) events, but later also for normal operation.

GETTER is a legacy code from the German HTR program also developed by HRB, bought and further developed by PBMR to include PBMR-specific requirements such as iodine release determination under accident conditions. GETTER is a multipurpose tool and has found use in diverse applications at PBMR such as spent fuel tank contamination calculations, temperature transients and accident event investigations, and evaluation of irradiation tests and post irradiation examinations (PIE).

Two physical models are applied when using the calculation model. First, the fuel element model is based on German reference fuel made up of TRISO particles embedded in A3-3 graphite matrix material. Second, the reactor model is based on a spherical fueled HTGR core design with a static central column as modeled by VSOP and TINTE. This calculation model is based on German reference fuel and assumes that the fuel utilized will be the same or better quality than German reference fuel. Therefore all transport and fuel parameters as developed and determined by the German fuel program are used. The calculation is performed for the best estimate or expected case using all best estimate input parameters and values. A sensitivity analysis is performed on all uncertain input parameters and values to determine design limits.

\section{E-4. DAMD}

DAMD (Dust and Activity Migration and Distribution) models the activation, migration, and time dependent distribution of dust and fission products in an HTGR. DAMD was developed specifically for integrated effects modeling within a typical pebble bed HTGR system. The ability to perform sensitivity analyses with DAMD to evaluate system responses provides the capability to define bounding cases for the PBMR design and safety evaluations.

DAMD models condensable fission product deposition rates in the MPS by explicit modeling of flow conditions (hydraulic force) and gravity force and by lumped (nonexplicit) modeling of thermophoresis and van der Waals forces. The code models liftoff of condensable fission products by explicit modeling of flow conditions, transient forces, and centrifugal forces, and by lumped modeling of vibrations and van der Waals forces. As discussed in Section 4.6.2 of this white paper, the DAMD code is being calibrated against AVR reactor performance. 


\section{E-5. EXCEL1}

EXCEL1 is a specially developed EXCEL application to do post-calculation data manipulation of NOBELG and FIPREX/GETTER output in calculating fission product release from the PBMR MPS to the reactor building under accident conditions.

\section{E-6. ASTEC}

Radionuclide behavior in the PBMR reactor building is modeled using the ASTEC (Accident Source Term Evaluation Code) program. ASTEC has been developed jointly over a number of years by the French group IRSN (L'Institut de Radioprotection et de Sûreté Nucléaire) and its German counterpart, GRS (Gesellschaft für Anlagen und Reaktorsicherheit $\mathrm{mbH}$ ). The aim of the code as initially developed was to simulate an entire LWR severe accident sequence from the initiating event through to the radionuclide release out of the containment. The program consists of two primary modules, which simulate the thermal-fluid and aerosol behavior in containment. In ASTEC, the containment is discretized through a "lumped-parameter" approach (i.e., volumes are represented by nodes connected by junctions). This approach allows the simulation of simple or multi-compartment containments with possible leakages to the environment or to normal buildings. Zones in ASTEC are defined by their floor area, volume, floor height and zone centre height. The initial conditions of the zone such as the initial pressure, temperature and humidity are specified. Fission products are defined as either being attached to dust or being transported with the helium in aerosol form. The mass injection rate as a function of time is used for the fission product injection. For the case of modeling fission products as aerosols, the aerosol properties are defined. ASTEC can model the following aerosol and fission product behavior: coagulation, thermophoresis and diffusiophoresis; filtration; steam condensation onto aerosols; washing; and aerosol removal by spray. 